\title{
Implications of Machine-Learning, Internet-Tests to Save Lives and Money: "7-Point Violence Profile:" Review of 212 Studies, 320,051 Persons, Over 95 Years, With a Cross-Validation Among 136 Homicidal, Overdosing- Substance-Abusing, Sex-Offending, Suicide-Completers, and Controls
}

\author{
Robert John Zagar ${ }^{1}$, Steve A. Varela ${ }^{2}$, Kenneth G. Busch ${ }^{3}$, James Garbarino ${ }^{4}$, Agata Karolina Zagar ${ }^{5}$, Joseph W. Kovach ${ }^{6}$, \\ Steve Tippins ${ }^{7}$, John Russell Hughes ${ }^{8}$, Ishup Singh $^{9}$ \\ ${ }^{1}$ Consultant, Juvenile Division, Cook County Circuit Court, Chicago, IL., U.S.A. \\ ${ }^{2}$ Business Management Department, Calumet College of Saint Joseph, Whiting, IN., U.S.A. \\ ${ }^{3}$ Chicago, IL., U.S.A. \\ ${ }^{4}$ Psychology Department, Loyola University Chicago, IL., U.S.A \\ ${ }^{5}$ Actuarial Risk Tests, L.L.C., Chicago, IL., U.S.A \\ ${ }^{6}$ Psychology Department, Calumet College of Saint Joseph, Whiting, IN, U.S.A \\ ${ }^{7}$ College of Management and Technology, Walden University, Minneapolis, MN., U.S.A \\ ${ }^{8}$ Neurology Department, University of Illinois Health Sciences Center \& School of Medicine, Chicago, IL., U.S.A \\ ${ }^{9}$ Psychology Department, Calumet College of Saint Joseph, Whiting, IN., U.S.A
}

Correspondence: Robert John Zagar, Actuarial Risk Tests, L.L.C., 233 East Erie Street, Suite 404A, Chicago, Illinois 60611-4675, USA. E-mail: doctorzagar@gmail.com.

Received: October 8, 2018 Accepted: January 14, 2019 Online Published: February 15, 2019

doi:10.5539/res.v11n1p106 URL: https://doi.org/10.5539/res.v11n1p106

\begin{abstract}
Analysis of 136 persons with psychopathology, suicidal ideation, violence included: (a) 79 adults [12 homicidal, 13 overdosing-substance-abusers, 15 sex-offending, 15 suicide-completers, 24 controls ( 23 women, 56 men) $M_{\text {age }}=38.29$ ]; (b) 57 teens [11 homicidal, 7 overdosing-substance-abusers, 10 sex-offending, 17 suicide-completers, 12 controls (15 girls, 42 boys) $M_{\text {age }}=15.37$ ] given (Standard Predictor of Violence Potential (SP), Quick Test (QT), Beck Scale (BSS), MMPI-2/A, Raven Matrices). Significant $(p<.05)$ ANOVA $F s$ were: (a) adults (SP, BSS, MMPI-2 [VRIN, F, F B $_{\text {, F }}$, L, K, S, Hs (1), D (2), Pd (4), Mf (5), Pa(6), Pt(7), Sc (8), Ma (9), Si (10), MAC-R, APS, AAS], Raven; (b) teens (SP, BSS, MMPI-A [F , F, L, K, D (2), Pa (6), Sc (8)], QT. At-risk, adults, teens had the same "7-point violence profile" (SP -, "F/L-2-4-6-8-AAS(ACK)") [insignificant differences $(p<.05)$ ANOVA-Fs: SP, BSS, MMPI-2/A: F, L, K, D (2), Pd (4), $\mathrm{Pa}(6), \mathrm{Sc}(8)]$.
\end{abstract}

Keywords: machine-learning, internet-testing violence-prediction, homicidal, overdosing, sex-offending, suicide-completers

For over 500 years, academics and business persons developed risk equations to save lives and money. There were 212 studies of 320,051 persons over 95 years, demonstrating a consistent, reliable, sensitive, specific and valid "7-point violence profile", consisting of eight measures (violence potential [Standard Predictor], suicide ideation [Beck Scale of Suicidal Ideation], deception [faking and lying], depression, psychopathic deviance, paranoia, schizophrenia, and addiction [MMPI-2/A]). We confirmed this "7-point violence profile" in a random, adult, and teen sample of 136 by comparing homicidal, overdosing-substance-abusing, sex-offending, and suicide-completers with controls. Not only do these four different groups have this "7-point violence profile" (See Figures 4 and 5), but the profile is similar for each of these four at-risk groups, and the same for at-risk adults or teens. Why is demonstrating a "7-point violence profile" crucial? Over the past 28 years, 3,989,552 victims (sex offenders and deaths), and \$7,575,181,909,483 were lost (see Table 4). The current study is consistent with the implication and proposal, which wider machine-learning, internet-test 
(MLIT) use by court, hospital, and human resource professionals can result in saving lives and expense over the next 28 years, and onward.

MLIT are inexpensive, objective, reliable, sensitive, specific, and valid, featuring 97\% accuracy and precision in finding at-risk, compared with current ways or approaches (background-credit checks, interviews-judgment, medical exams, and paper-and-pencil tests) at 39\% [that is a miss rate or inaccuracy and imprecision of $61 \%$ ]. Currently, most court, hospital, and human resource professionals use conventional ways, which have a combined sensitivity-specificity of .39 (Zagar, Zagar, Arbit, Bartikowski, Busch, et al., 2008; Zagar and Grove, 2010; Zagar, Kovach, Basile, Hughes, and Grove, 2013; Zagar, Zagar, Zagar, Busch, Garbarino, Ferrari, et al., 2016). See Figure 1.

Why are the current ways less than chance accurate? Perhaps, as Pope, Butcher and Seelan (2006) demonstrate, that the popular MMPI Second and Adolescent Editions (MMPI-2/A) have seven objective, reliable, sensitive, specific and valid measures of deceptive self-presentation (infrequency, lying, defensiveness, faking at the back of the test, true inconsistency, false inconsistency, and superlative self-presentation). If one takes these seven different deceptive selfpresentations, and puts them into a Poisson's distribution of seven (validity scales measuring deceptive self-presentation) $7 \times 6 \times 5 \times 4 \times 3 \times 2$, that results in 40,300 ways to deceive a court, hospital or human resource professional. This is further complicated by the fact that there are 1,000 neurological and psychiatric illnesses (International Classification of Diseases Tenth Edition, World Health Organization, 2013 and Diagnostic Statistical Manual Fifth Edition, American Psychiatric Association, 2013), which results in a total of 40,300,000 deceptive, neurological and psychiatric, selfpresentations. Given 40,300,000 ways to deceptively self-present, MLIT must be added to current methods of assessment, which court, hospital, and human resource professionals use.

No human can match a computer equation, that can compare the person, against millions in data bases and recall millions of equations simultaneously (Siegel, 2016; Zagar, et al., 2016). A computer can remember 40,300,000 equations, and match the individual against hundreds of thousands of persons, for which both test data and criterion information (i.e., homicide, mass murder, overdose, sex-offending, and suicide) exist. See Figure 2. This deceptive self-presentation along with the fact that only computer algorithms can reliably, sensitively, specifically and validly identify at-risk (homicidal, overdosing-substance-abusing, sex-offending and suicide-completers), partially accounts for the 3,989,552 victims (sex-offenders and deaths) and \$7,575,181,909,483 lost over the past 28 years (see Table 4).

Most court hospital and human resource professionals are not statistically savvy enough to realize that the conventional approaches of background-credit checks, interviews-judgment, medical exams, and paper-and-pencil tests have a combined 39\% hit rate, which is less than chance. For nearly seven decades, these professionals believe their interview skills and judgment are better than a computer algorithm despite the scientific evidence to the contrary. In a perverse reverse logic, these same professionals consider themselves superior to a logical, objective computer equation, when in fact they are less than chance accurate. So, the purpose of this paper is to demonstrate that for nearly a century in examining a third of a million of persons, an objective, reliable, sensitive, specific, and valid "7-point violence profile" exists, and should be used with MLIT to predict and prevent homicide, overdosing-substance-abusing, sex-offending, and suicide-completers.

\section{Paper Outline: Seven Sections (1-7)}

This paper includes: (a) the costs of using current ways of finding risk; (b) a contrast of the current ways of assessment versus MLIT, actuarial assessment; (c) the four reviews of the MMPI/MMPI-2/A studies on (1) homicidal, (2) overdosing-substance-abusing, (3) sex-offending, and (4) suicide-completers; (d) the two sets of reviews on dangerous and violent behavior in (1) teens and (2) adults; (e) the summary of the common "7-point violence profile" across homicidal, overdosing-substance-abusing, sex-offending and suicide-completers, namely high Standard Predictor of Violence Potential (SP) scores, and increased "L/F-2-4-6-8-AAS(ACK)" MMPI-2/A profiles of lie, infrequency, depression, psychopathic-deviate, paranoia, schizophrenia and addiction (admission or acknowledgement); (f) the presentation of a cross-validation study with the MLIT on 136 homicidal, overdosing-substance-abusing, sex-offending, suicide-completers vs. controls demonstrating the "7-point violence profile"; and (g) the discussion of how applying MLIT more widely might save millions of lives and trillions in U.S. dollars.

\section{The Costs of Using Current Ways of Finding Risk}

There are costs of using current ways without MLIT, which have a sensitivity-specificity of .91-.99 (Zagar et al., 2008; $2010 ; 2013 ; 2016)$. The challenge in finding at-risk was deceptive self-presentation among those with neurological and psychiatric illnesses not discovered with current ways. The twelve issues of using the current ways at intake, discharge or promotion include: (1) the psychiatric over hospitalization avoided due to insensitive, nonspecific diagnosis; (2) the civilian homicides, overdoses, and suicides, not found at courts, hospitals and human resources; (3) the air, bus, train, and truck transport deaths, not predicted and prevented during routine physicals; (4) the cumulative daily and yearly, veteran suicides, not found, when former military are discharged, or seek medical attention; (5) the professional athlete, 
coach, and trainer crimes and sex-offending, that cause loss of earnings, ticket and merchandise sales; (6) the nonprofit, religious groups pedophilia payouts, and lost collections, due to not screening at intake and promotion; (7) the jailing nonviolent and or mentally ill offenders, rather than diverting to electronic monitoring bracelets or other diversions; (8) the health care worker, physician, professor, teacher, and caretaker losses from violence to self and others, from not assessing; (9) the public-safety, personnel suicides, deaths-in-the-line-of-duty, and malfeasance payouts from not screening; (10) the mentally ill, mass murderers or active shooters, not found when seeking medical services, employment or police contact by failing to discover bipolar, schizophrenic, paranoid or other psychiatrically impaired persons; (11) the energy worker (coal, electricity, nuclear, oil, petroleum, and solar) losses from violence at routine physicals; and (12) the military (including national guard) homicides and suicides, by not screening at draft, promotion, discharge from service, or post-battlefield experience. See Table 4. The importance of using MLIT added to the current approaches is also emphasized in the nearly 129,435 U.S. 2016 combined homicides, mass murders, overdosing-substance-abusing, sex offenses, and suicides (FBI, 2012, Zagar, et al. 2016, CDC, 2017, 2018). There are also 861,837 U.S. convicted sex-offenders (U.S. Department of Justice, Bureau of Justice Statistics, 1997, National Center for Missing and Exploited Children, 2017).

\section{Contrast of the Current Ways of Assessment vs. MLIT Actuarial Assessment}

See Figure 1 for a comparison of the current ways contrasted with MLIT. There are paper-and-pencil tests, interviews and judgment, medical exams, and the modern MLIT: (a) the paper-and-pencil, violence risk tests, have a mean sensitivity and specificity of .73 [as contrasted with a miss rate of 27\%] (Quinsey, Harris, Rice, and Courmier, 1998, 2006, 2015; Hanson and Thornton, 2000; Monahan et al., 2000); the background-credit checks hit rate is .25 [as compared with a miss rate of 75\%](Quinsey, Harris, Rice, and Cormier, 1998; 2006; 2015); (b) the interviews and judgment, have an average hit rate of .46 (as opposed to a miss rate of .54) [Sepejak, Menzies, Webster, and Jensen, 1983; Lidz, 1993; Monahan, 1996; Rice, Harris, and Quinsey, 1996]; (c) in 2,200 medical and psychiatric exams, there is a mean .49 hit rate [versus a miss rate of $51 \%$, which exceeds chance] (Hsieh, Gutman, and Haliscak, 2000; Loke, Liaw, Tiong, Ling, and Chang, 2002; Madan and Harley, 2003; Bueno-de-Mesquita, Nuyten, Wesseling, van Tinteren, Linn, and van de Vijver, 2009; Zagar, Kovach, Basile, Hughes, Grove, et al., 2013); and (d) the Standard Predictor of Violence Potential, along with the MMPI-2/A, have a combined specificity and sensitivity for deception, mental illness, substance abuse and violence of 0.97 (Zagar and Grove, 2010; Zagar, Kovach, Basile, Hughes, Grove, et al., 2013) for homicidal, overdosing-substance-abusing, sex-offending and suicide-completers.

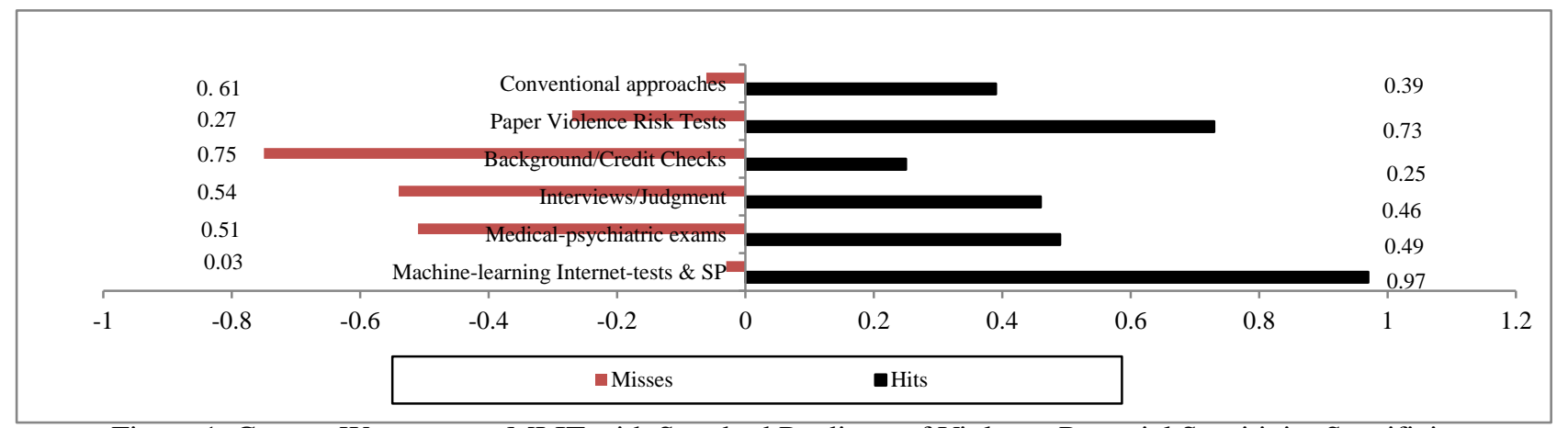

Figure 1. Current Ways versus MLIT with Standard Predictor of Violence Potential Sensitivity Specificity

\subsection{MLIT Actuarial Assessment}

Zagar and Grove (2010) with $N=2,722$ showed that homicide, sex offending, and assault was predicted accurately and precisely ( $A U C$ for 1,595 adults $=.99, A U C$ for 1,127 youth $=.91$ and $A U C=.96$ for 2,722 combined). Zagar, Kovach, Basile, Hughes, Grove et al., 2013, and Zagar, et al., 2016 showed that MLIT, actuarial assessment is more objective, reliable, sensitive, specific and valid, than current approaches with $.97 \mathrm{vs} .39$, for homicide, sex-offending and suicide. In a 50 year meta-analysis of suicide research, Franklin, Fox, Bentley, Kleiman, Huang, et al., (2017) discovered that MLIT was superior to find risk factors for suicidal thoughts and behavior. For suicide, Walsh, Ribeiro, and Franklin (2017) developed MLIT algorithms that accurately predicted future suicide attempts $(A U C=0.84$, precision $=0.79$, recall $=0.95$, Brier score $=0.14)$. In neurology, Titano, Badgely, Schefflein, Pain, Andres, Michael et al., 2018 showed that the MLIT algorithm could decide whether a CAT scan of an emergency room patient demonstrated signs of a stroke, by using automated deep-neural-network surveillance of cranial images for acute neurologic events that are 150 times faster than a human judge. In retinal disease, DeFauw, Ledsam, and Ronneberger (2018) found that clinically applicable deep learning was superior, because there is a shortage of experts who can interpret the millions of diagnostic eye exams performed each year. Artificially intelligent assistants help immensely.

So MLIT actuarial assessment is the future for at-risk persons. The purpose of this study is to show that adding MLIT to 
the current ways of assessing persons in courts, hospitals, and human resources if more widely used would eventually save lives and expense. The aim is to confirm or cross-validate in an independent randomly selected sample that this "7point violence profile" exists. We will not cover the entire literature on these tests and the diversions, interventions or treatments, of these at-risk states and tests used in finding these at-risk. The results of a small cross-validation sample of 136 are presented which demonstrate the persistent results of this earlier research reviewed. Finally, there is discussion of how to save lives and expense by applying MLIT in the twelve above mentioned issues listed in Table 4.

\section{MMPI/MMPI-2/A Studies of Homicidal, Overdosing-Substance-Abusing, Sex-Offending, \& Suicide-Completers}

On the MMPI, MMPI-2/A over 95 years (1923 to 2017), there were 141 studies of 128,435 homicidal or violent prone, overdosing-substance-abusing, sex-offending, and suicide-completers, in five countries and two continents. Among these studies, there was a consistent pattern of the elevated deception, depression, psychopathic deviate, paranoia, schizophrenia and addiction scales or "L/F-2-4-6-8-AAS (ACK)" MMPI/MMPI-2/MMPI-A subtests across the abovementioned at-risk groups. See Tables 1a, 1b, 1c, and 1d.

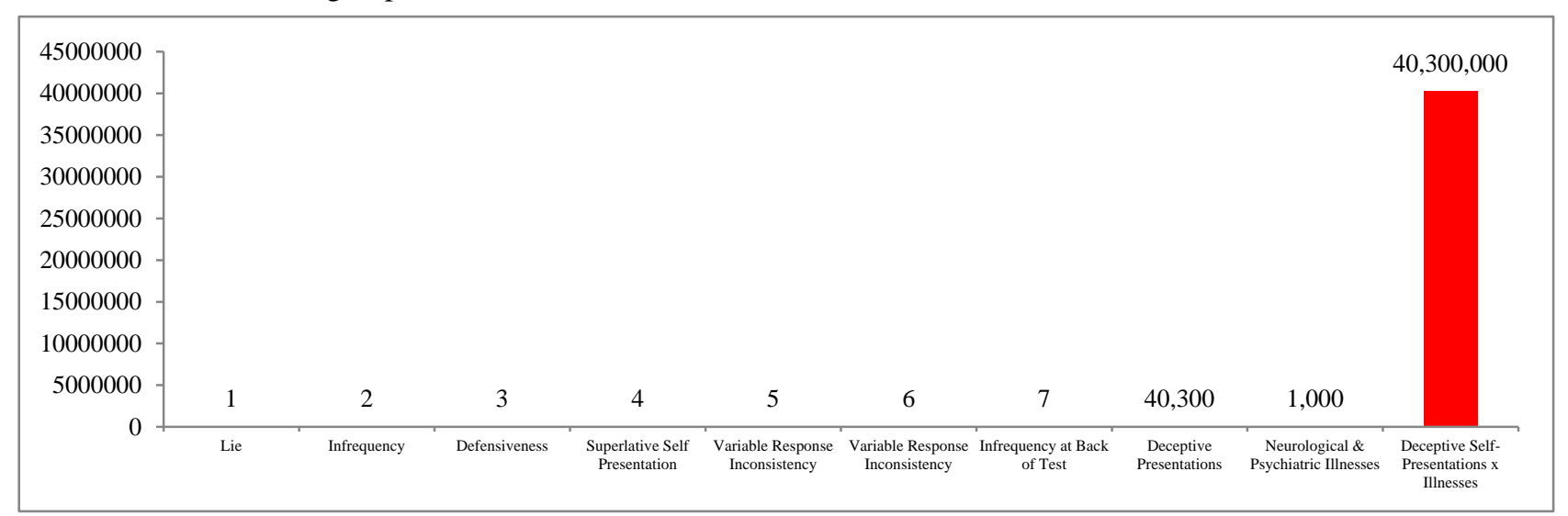

Figure 2. 40,300,000 Deceptive, Neurologic and Psychiatric Self-Presentations

Over 95 years, among 70 studies of 160,130, there were also consistent results of finding "return to court" or violence re-offending or "dangerous" behavior (probation and parole decision making tests). Researchers repeatedly proved that one can predict "return-to-court" or dangerous violent reoffending or "dangerous" behavior, to detect, apprehend, re-convict, and imprison the recidivist prone person. Combining the MMPI-2/A and probation and parole decision making tests like the Standard Predictor of Violence Potential resulted in 212 studies of 320,051 over 95 years, which conclusively are consistent with the "7-point violence profile."

\subsection{Homicidal, MMPI and MMPI-2/A Studies: "7-Point Violence Profile"}

Among 21,130 homicidal, serial killing, and violent offenders in 44 studies over 65 years, there were consistent elevations of deception, depression, psychopathic deviate, paranoia, schizophrenia, and addiction scales or a high "F-2-4-6-8" MMPI-2 profile (See Table 1a). This included: infrequency (F); depression (2); psychopathic deviate (4); paranoia (6); and schizophrenia (8) MMPI scaled scores and familial discord (Pd1); authority problems (Pd2); social (Pd4); and self-alienation (Pd5) subscales ["Pd1, Pd2, Pd4, Pd5"]. There were high " 4 " scores, in 37 studies $(n=20,159)$. There were elevated "4-6-8" scores, in 30 studies $(n=16,554)$. There were elevated " $F$ " scores among 26 researchers $(n=13,909)$. There were increased "F-4-6-8" scores, within 21 papers $(n=13,484)$. There were high "2-4-8" subtest scores, within 24 papers $(n=12,081)$. There were elevated " $2-4-6-8$ " scores, in 23 papers $(n=11,528)$. There were above normal "F-2-4-6-8" scores, in 17 experiments $(n=10,355)$. There were significantly raised "Pd1-2-4-5"scores, in 4 papers ( $n=629)$. There was a reliable pattern of high " $F-2-4-6-8-P d 1-2-4-5$ "scores. However, many believe that the MMPI alone cannot differentiate homicidal, serial killing or violent proclivity. This is why parole and probation decision making test and the Standard Predictor of Violence Potential, were developed to be used with the MMPI. These measures of violence add to the MMPI-2/A or other tests and increase objectivity, reliability, sensitivity specificity, and validity by finding all four risk domains (deception, psychopathology, substance abuse, and violence). In studies by Zagar and Grove (2010) and Zagar, et al., (2013), the Standard Predictor of Violence Potential with the MMPI-2/A and BSS, measures all four risk domains (deception, psychopathology, substance abuse, and violence potential) with $97 \%$ sensitivity-specificity. Given thousands of cases, and dozens of studies in different places and unique times, homicidal, serial killers and violent prone, have a consistent elevated SP, BSS and "F-2-4-6-8" MMPI/MMPI2/A scores. 
Table 1a. Summary of MMPI, MMPI-2/A, and Standard Predictor for Homicidal (1 of 4)

\begin{tabular}{|c|c|c|c|c|}
\hline Risk & & Study & Sample & High Test/Subtest \\
\hline Homicidal & 1 & Fry, 1949 & $\begin{array}{l}98 \text { men, } 109 \text { female prisoners, } 121 \text { men, } 115 \text { women } \\
\text { students, } 443 \text { total }\end{array}$ & $\begin{array}{l}\text { Males, 1-2-4-6-8-9 females, } \\
1-3-9\end{array}$ \\
\hline 44 Studies & 2 & Clark, 1952 & 136 disciplined, Army, prisoner soldiers & $2-4-9$ \\
\hline 21,130 & 3 & Smith, 1955 & 400 violent and 400 nonviolent prisoners, 800 total & 4 \\
\hline MMPI & 4 & Rosen \& Mink, 1961 & 52 Male violent and nonviolent prisoners and controls & $2-3-4-6$ \\
\hline F-2-4-6-8 & 5 & Lawton \& Kleban, 1965 & 32 Violent and nonviolent prisoners & $4-9$ \\
\hline Pd1-2-4-5 & 6 & Jacobson \& Wirt, 1968 & 100 Violent and 100 nonviolent prisoners, total 200 & $2-3-7$ \\
\hline Standard & 7 & Davis \& Sines, 1971 & $\begin{array}{l}500 \text { patients, } 1,136 \text { prisoners, } 625 \text { students, } 30 \text { Violent, total } \\
2,361\end{array}$ & $3-4$ \\
\hline Predictor & 8 & Persons \& Marks, 1971 & 48 violent prisoners & 3-4 (85\% had violence history) \\
\hline of & 9 & Sutker \& Moan, 1973 & 104 Violent and nonviolent prisoners & $\mathrm{F}-4-9$ \\
\hline Violence & 10 & Panton, 1976 & $\begin{array}{l}21 \text { murderers, } 11 \text { rapists, } 2 \text { robbers }=34 \text { of 2,551 death row } \\
\text { prisoners }\end{array}$ & F-2-4-6-8 \\
\hline Potential & 11 & Megargee, 1977 & $\begin{array}{l}1,213+443 \text { violent }+ \text { nonviolent prisoners, } 60 \text { serial killers, } \\
\text { total } 1,716\end{array}$ & F-4-6-8 \\
\hline \multirow[t]{33}{*}{ BSS } & 12 & Rader, 1977 & 46 assaulters & 4-8 (assaulters) \\
\hline & 13 & Sutker, Allain, \& Geyer, 1978 & 150 male and 180 female murderers, 330 total & F-K-4-5 \\
\hline & 14 & Megargee \& Bohn, 1979 & 1,344 violent offenders & $4-6-8$ \\
\hline & 15 & Quinsey, Arnold \& Pruesse, 1980 & 150 murderers and violent prisoners & $2-4-6-8$ \\
\hline & 16 & Jones, Beidleman, \& Fowler, 1981 & 141 violent and nonviolent prisoners & F-6-7-8 (72\% violent) \\
\hline & 17 & Holcomb \& Anderson, 1983 & 110 murderers & $2-4$ \\
\hline & 18 & Holcomb, Adams, Ponder, \& Anderson, 1984 & 96 murderers & F-6-8 \\
\hline & 19 & Holcomb \& Adams, 1985 & 259 murderers & $2-4$ \\
\hline & 20 & Holcomb, Adams, \& Ponder, 1985 & 80 murderers & F-2-4-6-8 \\
\hline & 21 & Guy, Platt, Zwerling, \& Bullock, 1985 & 486 violent and nonviolent prisoners & $2-4-6-8$ \\
\hline & 22 & $\begin{array}{l}\text { Ingram, Marchioni, Hill, Caraveo-Ramos, \& } \\
\text { McNeil, } 1985\end{array}$ & 52 prisoners violent and nonviolent & F-3-4 \\
\hline & 23 & Cornell, Miller, \& Benedick, 1988 & 36 homicidal, 18 larceny, 54 total & F-1-3-8 \\
\hline & 24 & Pavelka, 1986 & $\begin{array}{l}\text { Random sample of } 86 \text { of } 261 \text { violent and nonviolent } \\
\text { prisoners }\end{array}$ & $2-4$ (62\% violent) \\
\hline & 25 & Kalichman, 1988a & $\begin{array}{l}20 \text { matricides, } 16 \text { patricides, } 19 \text { murderers, total } 55 \\
\text { homicidal }\end{array}$ & $\begin{array}{lll}\begin{array}{l}\text { patricides } \\
\text { murderers } 4\end{array} & 4-6-8 \text { matricides } \\
\end{array}$ \\
\hline & 26 & Kalichman ,1988b & 118 murderers & F-2-4-6-8 \\
\hline & 27 & $\begin{array}{l}\text { Wasiliw, Grossman, Haywood, \& Cavanaugh, } \\
1988\end{array}$ & 74 Violent and nonviolent prisoners & F-2-4 \\
\hline & 28 & Carmin, Wallbrown, Ownby, \& Barnett, 1989 & 671 Violent and nonviolent prisoners & Five factors \\
\hline & 29 & Biro, Vuckovic, \& Djuric, 1992 & 112 murderers & $2-4-6-8$ \\
\hline & 30 & Shea \& McKee, 1996 & 135 murderers and 82 other crimes total 217 & F-2-4-6-8 \\
\hline & 31 & Graham, 2000 & Violent and nonviolent prisoners & $4-6-8$ \\
\hline & 32 & McKee, Shea, Mogy, \& Holder, 2001 & 30 filicides, 19 matricide, 24 murderers, 73 total murderers & $\begin{array}{l}\text { Filicides, matricides, murderers } \\
\text { F-2-4-6-8 }\end{array}$ \\
\hline & 33 & Megargee, Carbonell, Bohn, \& Sliger, 2001 & 1,344 violent and nonviolent offenders, 60 serial killers & F-4-6-8 \\
\hline & 34 & Pennuto, 2004 & $\begin{array}{l}1700 \text { court cases, } 435 \text { murder cases, most for mental } \\
\text { competence }\end{array}$ & F-2-4-6-8 \\
\hline & 35 & Megargee 2006; 2008 & 1,344 Violent and nonviolent prisoners, 60 serial killers & F-4-6-8 \\
\hline & 36 & Craig, 2008 & 1,114 murderers (30 studies reviewed) & F-2-4-6-8 \\
\hline & 37 & Romo, 2009 & 8 serial murderers & F-4-6-8-Pd1-Pd2-Pd-4-Pd5 \\
\hline & 38 & $\begin{array}{l}\text { Spaans Barendregt Muller de Beurs Nijman \& } \\
\text { Rinne, } 2009\end{array}$ & 247 violent offenders & F-2-4-6-8 \\
\hline & 39 & Pennuto, 2010 & Review of murderers & F-2-4-6-8 \\
\hline & 40 & Grover, 2011 & $\begin{array}{l}\text { Review violent prisoners, sex offenders, nonviolent } \\
\text { prisoners }\end{array}$ & F-L-2-4-6-8 \\
\hline & 41 & Zagar \& Grove, 2010 & $\begin{array}{l}324 \text { murderers, } 450 \text { assaulters, } 1,220 \text { violent prone, } 2,272 \\
\text { total }\end{array}$ & $\begin{array}{l}\text { SPF2-4-6-8-AAS } \\
\text { Pd1-2-4-5 }\end{array}$ \\
\hline & 42 & $\begin{array}{l}\text { Zagar, Kovach, Basile, Grove, Hughes, et al., } \\
2013\end{array}$ & $\begin{array}{l}236 \text { patients, prisoners, students, workers, } 4 \text { homicidal, } 29 \\
\text { violent prone }\end{array}$ & $\begin{array}{l}\text { SP- } \begin{array}{l}\text { F-2-4-6-8-AAS } \\
\text { (ACK)-Pd1-2-4-5 }\end{array} \\
\end{array}$ \\
\hline & 43 & Culhane, Hildebrand, Walker, \& Gray, 2014 & 61 serial murderers & F-Fb-4-6-8-Pd1-Pd2-Pd4-Pd5 \\
\hline & 44 & Brad, Coupland, \& Oliver, 2014 & 95 murderers & F-2-4-6-8 \\
\hline
\end{tabular}

\subsection{Overdosing-Substance-Abusing, MMPI, and MMPI-2/A Studies: "7-Point Self-Destructive Violence Profile"}

As seen in Table $1 \mathrm{~b}$ within 22 studies of 66,839 overdosing-substance-abusing teens and adults, there were consistently 
high SP, BSS and MMPI-2/A Mac Andrew's alcoholism Scale scores (MAC or MAC-R), addiction acknowledgment (AAS), addiction potential [for adults] (APS), alcohol-drug problem proneness [for teens] (PRO), and alcohol-drug problem acknowledgement (ACK) scores, lie (L), depression (2), psychopathic deviate (4), paranoia (6), schizophrenia (8) or "L-2-4-6-8" scores. There were high "MAC" scores, in 17 studies $(n=64,957)$. There were increased "MAC-R" scores, within 10 papers $(n=57,066)$. There were elevated "MAC-R-AAS-APS" scores among 6 researchers $(n=21,997)$. There were above normal "MAC-R-AAS-APS-2-4-6-8" scores in 2 experiments $(n=1,754)$. There was a high "MAC-R-ACK-PRO" score, in 1 paper ( $n=833)$. With the elevated "MAC-R-AAS-APS" or high "MAC-R-ACK-PRO" or increased "2-4-6-8" MMPI scales, these were consistent with distinguishing overdosing-substance-abusing from controls. So, the computerized MMPI-2/A clinical interpretative report is often used to determine at-risk for overdose, suicide ideation, and suicide intent. Given thousands of cases and over a dozen studies in different locations, overdosing-substance-abusing, repeatedly, had the high SP, BSS, and MMPI-2/A "F-2-4-6-8" and "MAC-R-AAS-APS" scores (for adults) or "MAC-R-ACK-PRO" scores (for teens).

Table 1b. Summary of MMPI MMPI-2/A \& Standard Predictor for Overdosing-Substance-Abusing (2 of 4)

\begin{tabular}{|c|c|c|c|c|}
\hline Risk & & Study & Sample & High Test/Subtest \\
\hline Overdosing & 1 & Wolfson \& Erbaugh, 1984 & $\begin{array}{l}\text { teens and adults, } 135 \text { high schoolers, } 90 \text { psychiatric } \\
\text { inpatients } 81 \text { psych outpatients, } 100 \text { substance } \\
\text { abusers, } 306 \text { total }\end{array}$ & MAC cutoff scores \\
\hline Substance & 2 & Gottesman \& Prescott, 1989 & Review of 74 studies of alcoholics & MAC sensitive specific \\
\hline Abusing & 3 & Craig \& Olson, 1990 & 50 suicide attempting, 50 non-suicidal total 113 & F-2-4-6-8 \\
\hline 66,839 & 4 & Gartner, Graham, \& Archer, 1992 & $\begin{array}{l}\text { Teen, } 443 \text {, controls, psychiatric patients, substance } \\
\text { abusers }\end{array}$ & 4-MAC \\
\hline 22 & 5 & Basham, 1992 & 327 teen inpatients & 4-MAC \\
\hline Studies & 6 & $\begin{array}{l}\text { Weed, Butcher, McKenna, \& Ben-Porath, } \\
1992\end{array}$ & $\begin{array}{l}2,600 \text { controls, } 423 \text { psychiatric patients, } 1,212 \\
\text { abusers, } 4,235 \text { total }\end{array}$ & AAS, APS \\
\hline MMPI-2/A & 7 & Svanum \& Ehrmann, 1992 & 90 alcoholics & F-2-4-6-8-MAC \\
\hline F-2-4-6-8 & 8 & $\begin{array}{l}\text { Greene, Weed, Butcher, Arrendondo, \& } \\
\text { Davis, } 1992\end{array}$ & $\begin{array}{l}189 \text { psychiatric patients, } 126 \text { substance abusers, } \\
315 \text { total }\end{array}$ & AAS, APS, MAC-R \\
\hline MAC/MACR & 9 & Svanum \& Ehrmann, 1993 & $\begin{array}{l}156 \text { abusers, anxious, depressed, college students, } \\
R O C\end{array}$ & 2-3-MAC-R AAS APS \\
\hline AAS & 10 & Svanum, McGrew, \& Ehrmann, 1994 & $\begin{array}{l}308 \text { college students, } 33 \text { substance abusers, AAS } \\
R O C=.81 \text {, APS } R O C=.6 \text {, MACR } R O C=.58\end{array}$ & MAC-R, AAS, APS \\
\hline APS & 11 & Weed, Butcher, \& Williams, 1994 & $\begin{array}{l}\text { (teens) } 1,620 \text { controls, } 252 \text { psychiatric patients, } 462 \\
\text { abusers, } 2,334 \text { total }\end{array}$ & ACK, PRO, MAC-R \\
\hline ACK & 12 & $\begin{array}{l}\text { Stein, Graham, Ben-Porath, \& McNulty, } \\
1999\end{array}$ & 833 substance abusing teens & $\begin{array}{l}\text { MACRAASAPSACK } \\
\text { PRO 2-4-6-8 }\end{array}$ \\
\hline PRO & 13 & Miccuci, 2002 & 79 teen psychiatric patients & ACK, MAC-R-PRO \\
\hline Standard & 14 & Craig, 2005 & 32,000 substance abusers & MAC, MAC-R \\
\hline Predictor & 15 & Stein \& Graham, 2005 & 67 substance abusing delinquents & L- ACK-PRO \\
\hline of & 16 & Miller, Shields, \& Canfield, 2007 & 210 studies (AAS, $r=.7$ ) & MAC, MAC-R, APS \\
\hline Violence & 17 & Clements \& Heinz, 2010 & 338 university students & ROCsAASMACR APS \\
\hline Potential & 18 & Polimeni, Moore, \& Gruenert, 2010 & 921 substance dependent adults & MACRAASAPSF2468 \\
\hline \multirow[t]{4}{*}{ BSS } & 19 & Zagar \& Grove, 2010 & 921 substance abusers, 2,722 total, adults and teens & $\begin{array}{l}\text { SP-F-2-4-6-8 } \\
\text { AAP(ACK) }\end{array}$ \\
\hline & 20 & $\begin{array}{l}\text { Zagar, Kovach, Basile, Grove, Hughes, } \\
\text { Busch, Zablocki, Osnowitz, Neuhengen, } \\
\text { Liu, \& Zagar, } 2013\end{array}$ & $\begin{array}{ll}236 \text { patients, prisoners, students, \& workers, } 2 \\
\text { suicide-completers, } 4 \quad \text { homicidal, } \\
\text { overdosing-substance-abusers }\end{array}$ & $\begin{array}{l}\text { SP, Beck, } \\
\text { F/L-2-4-6-8-AAS(ACK) }\end{array}$ \\
\hline & 21 & $\begin{array}{l}\text { Dragisic, Dickov, Dickov, \& Mijatovic, } \\
2015\end{array}$ & $\begin{array}{l}100 \text { suicide attempting heroin addicts, } 100 \\
\text { non-suicidal addicts, } 200 \text { total }\end{array}$ & MAC-R, AAS, APS \\
\hline & 22 & $\begin{array}{l}\text { Dragisic, Jovanovic, Dickov, Bugarski, } \\
\text { Ivetic, \& Miskovic, } 2017\end{array}$ & $\begin{array}{l}150 \text { overdose heroin addicts, } 49 \text { suicide intent, } 101 \\
\text { non-suicidal addicts, } 300 \text { total }\end{array}$ & MAC-R, AAS, APS \\
\hline
\end{tabular}
3.3 Sex-Offending, MMPI and MMPI-2/A Studies: "7-Point Violence Profile"

As shown in Table 1c, there were 45 studies of 9,832 sex-offending teens and adults over 48 years (from 1971 to 2018) with consistently elevated: depression (2); psychopathic deviate (4); paranoia (6); and schizophrenia (8); or "2-4-6-8" MMPI scores. There were high "4-6-8" scores in 29 studies $(n=8,382)$. There were elevated "2-4-8" subtests within 29 papers $(n=8,176)$. There were increased " $2-4-6-8$ " scores in 25 papers $(n=7,765)$. There were high " $2-4-6-8$ " scores 
Table 1c. Summary of MMPI, MMPI-2/A and Standard Predictor for Sex-Offending (3 of 4)

\begin{tabular}{|c|c|c|c|c|}
\hline Risk & & Study & Sample & High Test/Subtest \\
\hline Sex & 1 & Carroll \& Fuller, 1971 & $\begin{array}{l}50 \text { sex offenders, } 50 \text { violent, } 50 \text { nonviolent, } \\
150 \text { total }\end{array}$ & $2-4-8$ \\
\hline Offending & 2 & McCreary, 1975 & 33 molesters & $4-8$ \\
\hline 45 & 3 & Rader, 1977 & 36 exposers, 37 rapists, 73 total & exposer 4-8 rapist 4-8 \\
\hline Studies & 4 & Armentrout \& Haure, 1978 & $\begin{array}{l}13 \text { rapists, } 21 \text { molesters, } 17 \text { sex offenders, } 51 \\
\text { total }\end{array}$ & F-2-6 \\
\hline$n=9,832$ & 5 & Panton, 1978 & 78 sex offenders & $4-6-8-9$ \\
\hline F-2-4-6-8 & 6 & Anderson, Kunce, \& Riche, 1979 & $\begin{array}{l}92 \text { incest cases, molesters, rapists, sex } \\
\text { offenders }\end{array}$ & F-2-4-8-9 \\
\hline MMPI2/A & 7 & Quinsey, Arnold, \& Pruesse, 1980 & 250 murderers and violent offenders & $2-4-8$ \\
\hline Standard & 8 & Kalichman, 1981 & 90 sex offenders & $2-4-6-8-9$ \\
\hline Predictor & 9 & Lanyon \& Lutz, 1984 & 90 adult sex offenders & F-2-4-6-8 \\
\hline of & 10 & Hall, Maiuro, Vitaliano, \& Proctor, 1986 & 406 sex offenders & F-2-4-5-6-7-8 \\
\hline Violence & 11 & $\begin{array}{l}\text { Erickson, Luxenberg, Walbek, \& Seely, } \\
1987\end{array}$ & $\begin{array}{l}403 \text { sex offenders, rapists compared and } \\
\text { prisoners }\end{array}$ & $2-4-6-8-9$ \\
\hline Potential & 12 & Levin \& Stava, 1987 & review & molesters 2-6-8-10 \\
\hline \multirow[t]{34}{*}{ BSS } & 13 & Walters, 1987 & $\begin{array}{l}28 \text { molesters, } 35 \text { rapists, } 75 \text { offenders, } 138 \\
\text { total }\end{array}$ & $2-4-6-8-9$ \\
\hline & 14 & $\begin{array}{l}\text { Kalichman, Craig, Shealy, } \\
\text { Szymanowski \& McKee, } 1989\end{array}$ & 123 rapists & $2-4-8$ \\
\hline & 15 & $\begin{array}{l}\text { Kalichman, Szmanowski, McKee, Taylor, } \\
\text { \& Craig, } 1989\end{array}$ & 120 rapists & F-2-4-6-8-9 \\
\hline & 16 & Hall, 1989 & 101 molesters & $2-4-8$ \\
\hline & 16 & O’Connor, 1990 & 127 sex offenders & $2-4-8$ \\
\hline & 17 & Duthie \& McIvor, 1990 & 90 molesters & $2-4-6-8$ \\
\hline & 18 & Langevin, Wright, \& Handy, 1990 & 479 sex offenders and controls & F-2-4-5-6-8 \\
\hline & 19 & Miner, Marques, Day, \& Nelson, 1990 & 48 volunteer 50 sex offenders, 98 total & F-L-4 \\
\hline & 20 & Kalichman, 1990 & 111 sex offenders & F-2-4-6-7-8-9 \\
\hline & 21 & Kalichman, Shealy, \& Craig , 1990 & 120 rapists & $2-4-6-8$ \\
\hline & 22 & Kalichman, 1991 & 144 molesters & $2-4-6-8$ \\
\hline & 23 & Kalichman \& Henderson, 1991 & 113 molesters & $2-4-6-7-8$ \\
\hline & 24 & $\begin{array}{l}\text { Shealy, Kalichman, Henderson, } \\
\text { Szymanowski, \& McGee, } 1991\end{array}$ & 90 molesters & F-2-4-6-7-8 \\
\hline & 25 & Hall, Graham, \& Shepherd, 1991 & 261 sex offenders & $2-4-6-7-8-9$ \\
\hline & 26 & $\begin{array}{l}\text { Kalichman, Dwyer, Henderson, \& } \\
\text { Hoffman, } 1992\end{array}$ & 110 molesters & $2-4-6-7-8$ \\
\hline & 27 & Lanyon, 1993 & $\begin{array}{l}\text { (males) } 130 \text { sex offenders, } 239 \text { controls, } 369 \\
\text { total }\end{array}$ & K-4 \\
\hline & 28 & Wilson, 1994 & $\begin{array}{l}25 \text { molesters, } 25 \text { rapists, } 25 \text { other crimes, } 25 \\
\text { controls, } 100 \text { total }\end{array}$ & F-4-6-7-8-9 \\
\hline & 29 & Heersink \& Strassburg, 1995 & 122 molesters & $2-4-6-8$ \\
\hline & 30 & Losada-Paisley, 1998 & $\begin{array}{l}21 \text { sex offenders, } 30 \text { non-offenders, } 60 \text { total } \\
\text { teens }\end{array}$ & $4-8$ \\
\hline & 31 & Watkins, 2000 & 25 molesters, 25 sex offenders, 50 total & Molesters 2-4 sex offenders 4 \\
\hline & 32 & Briley, 2001 & 99 exposers, molesters, rapists & \\
\hline & 33 & Geer, Becker, Gray, \& Krauss, 2001 & 179 sex offenders & F-L-4 \\
\hline & 34 & Pietrulewicz, 2006 & $\begin{array}{l}30 \text { heterosexual pedophiles, } 30 \text { controls, } 60 \\
\text { total }\end{array}$ & $2-4-6-8$ \\
\hline & 35 & Looney, 2007 & 24 pedophiles & F-2-4-6-8- Pd2-Pd5 \\
\hline & 36 & Nademin, 2009 & 121 internet and sex offending sex offending & L-F-4-8 \\
\hline & 37 & $\begin{array}{l}\text { Tomak,Weschler,Ghahramanlou-Holloway, } \\
\text { Virden, Elicia, \& Nademin, } 2009\end{array}$ & 48 internet and 104 sex offenders, 152 total & $4-8$ \\
\hline & 38 & Coxe \& Holmes, 2009 & 285 sex offenders & $4-6-8$ \\
\hline & 39 & $\begin{array}{l}\text { Tomak, } \\
\text { Ghahramanlou-Holloway, } \\
\text { Nademin, 2009 }\end{array}$ & 121 sex offenders & L-F-4-8 \\
\hline & 40 & $\begin{array}{l}\text { Busch, Zagar, Grove, Hughes, Arbit, } \\
\text { Bussell, \& Bartikowski, 2009 }\end{array}$ & $\begin{array}{l}223 \text { molesters, } 223 \text { nonviolent controls, } 223 \\
\text { rapists, } 669 \text { total teens }\end{array}$ & $\begin{array}{llr}\begin{array}{l}\text { L-2-4-6-8, } \\
\text { Predictor }\end{array} & \text { High } & \text { Standard } \\
\end{array}$ \\
\hline & 41 & Davis \& Archer, 2010 & Review & 4 moderate to large effect size \\
\hline & 42 & Zagar \& Grove, 2010 & $\begin{array}{l}234 \text { murderers, } 223 \text { molesters } 223 \text { rapists, } \\
450 \text { assaulters, } 1220 \text { violent prone, } 2722 \\
\text { total }\end{array}$ & SP- L-2-4-6-8-AAS (ACK) \\
\hline & 43 & Grover, 2011 & Review & L-F-4-8 MMPI-2/A AP \\
\hline & 44 & $\begin{array}{l}\text { Zagar, Kovach, Basile, Grove, Hughes, et } \\
\text { al., } 2013\end{array}$ & $\begin{array}{l}236 \text { patients, prisoners, students, and } \\
\text { workers, } 13 \text { sex offending, } 29 \text { violent }\end{array}$ & SP-L-F--4-6-8-AAS-ACK-Pd1245 \\
\hline & 45 & Oliver, Coupland, \& Kurtenbach, 2018 & 349 sex offenders & F-4-6-8-9 \\
\hline
\end{tabular}


within 24 papers $(n=7,595)$. There were above normal "F-4-6-8" scores in 12 experiments $(n=2,555)$. There were significantly raised "4-6-9" scores in 8 papers $(n=1,530)$. There were significantly increased "2-4-6-8-9" scores in 5 papers $(n=1,003)$. There were increased "L-2-4-6-8" scores within 2 papers $(n=3,391)$. There were above normal "L-2-4-6-8-Pd-2-Pd-5" scores in 1 paper $(n=236)$ with higher authority problems, and self-alienation "Pd-2-Pd-5" MMPI scores. Given thousands of cases in dozens of studies of sex-offending in different locales at various times, sex offenders repeatedly had increased SP, BSS and MMPI-2/A "L-2-4-6-8"scores.

\subsection{Adult Suicide, MMPI, and MMPI-2/A Studies: "7-Point Self-Destructive Violence Profile"}

As seen in Table 1d in 31 studies with 30,634 suicide-completers, attempters, and ideational, over 57 years (from 1958-2014), there was a constant MMPI/2/A profile of the elevated: depression (2); psychopathic deviate (4); paranoia (6); schizophrenia (8); or increased "2-4-6-8" scores with high SP and BSS scores. There were high "4-6-8" scores in 15 studies $(n=28,047)$. There were increased " $2-4-6$ " subtest scores within 13 papers $(n=27,680)$. There were elevated "2-4-6-8" scores among 13 researchers $(n=27,680)$. There were above normal "2-6-8" scores in 13 papers $(n=27,680)$. There were increased "2-7-8" scores within 4 papers $(n=799)$. There were significantly increased "1-2-6" scores within 1 paper $(n=283)$. There were above normal "1-2-7" scores in 1 experiment $(n=283)$. There was a significantly raised "1-2-8" score in 1 study $(n=283)$. There were above normal "1-2-7-8" scores in 1 research event $(n=283)$. Given tens of thousands of cases in dozens of studies from many places over decades at various times, suicide-completers, attempters and ideational had increased "2-4-6-8" MMPI/MMPI2/A, SP, and BSS scores.

\section{Reviews of Dangerous and Violent Behavior: Probation and Parole Decision Making Tests: Teens and Adults}

Next, there were 70 studies of 191,611 offenders over 95 years measuring with "return to court", probation parole, decision-making tests over a 1-10 year follow-up using 1-71 questions. Test sensitivity-specificity was from .59-.99 [receiver operating characteristic $(R O C)$ or area under the curve $(A U C)$ ]. See Tables $2 \mathrm{a}, 2 \mathrm{~b}, 2 \mathrm{c}$, and $2 \mathrm{~d}$. These tests are divided into teen and adult populations. In Table 2a, over 71 years, there were 13 studies of 31,581 delinquents with a unit item, regression, correlation, phi coefficient, receiver operating characteristic $(R O C)$, or area under the curve $(A U C)$ sensitivity or specificity in analyzing data. For the adult criminals, the 57 studies of 160,130 subjects over 95 years are presented in Tables $2 b$ and $2 c$, with 1 to 71 item tests and followed for 1-10 years with unit item statistics, coefficient alpha, Pearson product moment correlation, multiple regression, base expectancy, point bi-serial correlation, discriminant analysis, ROC, AUC, sensitivity, and specificity. So, looking across the homicidal, overdosingsubstance-abusing, sex-offending, and suicide-completers in 142 studies of 128,135 subjects over 70 years, and 70 studies of 191,611 delinquents and criminals for a combined 212 studies of 320,051 individuals, there was a consistent, replicated "7-point violence profile." See Table 2e for a summary.

The null hypotheses of the cross-validation of the "7-point violence profile" are: (1) there are no differences between adult homicidal and controls; (2) there are no differences between adult overdosing-substance-abusing and controls; (3) there are no differences between adult sex-offending and controls; (4) there are no differences between adult suicide-completers and controls; (5) there are no differences between teen homicidal and controls; (6) there are no differences between teen overdosing-substance-abusing and controls; (7) there are no differences between teen sex-offending and controls; and (8) there are no differences between teen suicide-completers and controls. The alternate hypotheses of the cross-validation of the "7-point violence profile" are: (1) adult and teen homicidal, overdosing-substance-abusing, sex-offending, and suicide-completers will be similar; and (2) homicidal, overdosing-substance-abusing, sex-offending and suicide-completers will have a similar "7-point violence profile."

\section{Homicidal, Overdosing-Substance-Abusing, Sex-Offending, Suicide-Completers \& Controls Method}

\subsection{Participants and Population: Random Selection}

The random sample of referrals and five adult and five teen study groups came from a Midwestern city with approximately 2,000,000 workers and students, during 26 years (1992 to 2018). See Figure 3. In any given day of the year, from 1992 to 2019, within Cook County, Chicago, Illinois, there were 50,000 Juvenile, and 90,000 Adult Court prisoners. This study's sample was independent of those reported, in prior research (Zagar, Arbit, Hughes, Bussell, and Busch, 1989; Busch, Zagar, Arbit, Hughes, and Bussell, 1990; Zagar, Arbit, Busch, Hughes, and Sylvies, 1991; Zagar, Zagar, Busch, Grove, Hughes, et al., 2009; Zagar and Grove, 2010; Zagar, et al., 2013). 
Table 1d. Summary of MMPI, MMPI-2/A \& Standard Predictor for Suicidal-Completers (4 of 4)

\begin{tabular}{|c|c|c|c|c|}
\hline Risk & & Study & Sample & High Test/Subtest \\
\hline Suicide & 1 & Simon \& Gilberstadt, 1958 & $\begin{array}{l}26 \text { veteran suicide completers, } \\
\text { psychiatric patients }\end{array}$ & 2 \\
\hline 31 & 2 & Faberow \& DeVries, 1967 & 20 suicidal, Army soldiers & 2 \\
\hline Studies & 3 & Ravensborg \& Foss, 1969 & $\begin{array}{l}27 \text { suicidal, } 173 \text { suicide completers, } \\
109 \text { psychiatric patients, } 299 \text { total }\end{array}$ & 2 \\
\hline 30,634 & 4 & Lester, 1970 & $\begin{array}{l}52 \text { adult / teen male suicide } \\
\text { completers }\end{array}$ & 6 \\
\hline $2-4-6-8$ & 5 & Poeldinger, Gehring, \& Blaser, 1973 & $\begin{array}{l}9 \text { suicide attempters, } 28 \text { psychiatric } \\
\text { patients, } 37 \text { total }\end{array}$ & $2-3$ \\
\hline 100 & 6 & Leonard, 1974 & 70 suicide attempters & $2-0$ \\
\hline completers & 7 & Clopton \& Jones, 1975 & $\begin{array}{lll}22 & \text { suicide } & \text { completers, } \\
\text { non-suicidal } & & \\
\end{array}$ & $2-4-7-8$ \\
\hline 571 & 8 & Tarter, Templer, \& Perley, 1975 & $\begin{array}{l}50 \text { suicide attempters, } 50 \text { psychiatric } \\
\text { controls, } 100 \text { total }\end{array}$ & 2 \\
\hline attempters & 9 & Pallis \& Birtchnell, 1977 & $\begin{array}{l}136 \text { suicide attempters, } 147 \text { ideational } \\
233 \text { nonsuicidal, } 516 \text { total }\end{array}$ & $2-4$ \\
\hline 566 & 10 & Leonard, 1977 & $\begin{array}{l}36 \text { suicide completers, } 36 \text { ideational, } \\
36 \text { psychiatric patients, total } 108\end{array}$ & F-2-4-6-8 \\
\hline Ideational & 11 & Clopton \& Baucom, 1979 & $\begin{array}{l}20 \text { veteran suicide completers, } 20 \\
\text { non-suicidal, } 40 \text { total }\end{array}$ & MMPI profile \\
\hline Standard & 12 & Clopton, Pallis, \& Birtchnell, 1979 & $\begin{array}{l}75 \text { suicidal men, } 7 \text { suicidal women, } \\
201 \text { non-suicidal, } 283 \text { total }\end{array}$ & F-1-2-4-6-7-8 \\
\hline Predictor & 13 & Johnson, Lall, Bongar, \& Norland, 1979 & Review & $2-4-6-8$ \\
\hline of & 14 & Sendbuehler, Kincel, Nemeth, \& Oertel, 1979 & 184 suicide survivors & $2-4-5-6-8$ \\
\hline Violence & 15 & Jones, Heidleman, \& Fowler, 1981 & 141 prisoners, violent and nonviolent & F-4-6-7-8-9 \\
\hline Potential & 16 & $\begin{array}{l}\text { Waters, Sandbuchler, Kineel, Boodoosingh, \& } \\
\text { Marchenko, } 1982\end{array}$ & $\begin{array}{l}575 \text { total psychiatric patients and } \\
\text { suicidal }\end{array}$ & $2-4-5$ \\
\hline \multirow[t]{16}{*}{ BSS } & 17 & Clopton, Post, \& Larde, 1983 & $\begin{array}{l}161 \text { suicide attempters, } 161 \\
\text { non-suicidal, } 332 \text { total }\end{array}$ & $2-4-7-8$ \\
\hline & 18 & Watson, Klett, Walters, \& Laughlin, 1983 & $\begin{array}{l}25 \text { suicide completers, } 71 \text { ideational, } \\
96 \text { total }\end{array}$ & $2-4-6-8$ \\
\hline & 19 & Watson, Klett, Walters, \& Vassar, 1984 & $\begin{array}{l}84 \text { suicidal veterans, } 38 \text { psychiatric } \\
\text { patients, } 122 \text { total }\end{array}$ & $2-4-6-8$ \\
\hline & 20 & Spirito, Faust, Myers, \& Bechtel, 1988 & $\begin{array}{l}20 \text { teen suicide attempter, } 20 \text { teen } \\
\text { psychiatric patients, } 40 \text { total }\end{array}$ & F-2-4-8 \\
\hline & 21 & Sepaher, Bongar, \& Greene, 1999 & 23,646 psychiatric patients & $2-4-6-8$ \\
\hline & 22 & Archer \& Slesinger, 1999 & 348 teen suicidal and non-suicidal & $4-6-8-9$ \\
\hline & 23 & Johnson, Bongar, Lall, \& Borland, 1999 & Review & $2-4-6-8$ \\
\hline & 24 & Glassmire, Stolberg, Greene, \& Bongar, 2001 & 116 suicidal and psychiatric patients & 2 \\
\hline & 25 & Daigle, 2004 & $\begin{array}{l}47 \text { suicide completers, } 43 \text { suicide } \\
\text { attempters, } 123 \text { controls, } 213 \text { total }\end{array}$ & $2-4-6-8$ \\
\hline & 26 & Friedman, Archer, \& Handel, 2005 & Review & 2 \\
\hline & 27 & Zagar \& Grove, 2010 & $\begin{array}{l}289 \text { suicidal, } 2,722 \text { total adults and } \\
\text { teens }\end{array}$ & SP 2-4-6-8-AAS (ACK) \\
\hline & 28 & Romeo, Balducci, Quintarelli, Perbellini, et al., 2013 & 48 suicide ideation bullied at work & $1-2-3-6$ \\
\hline & 29 & $\begin{array}{l}\text { Pompili, Rihmer, Akiskal, Innamorati, Iliceto, } \\
\text { Akiskal, Lester, Narciso, Ferracuti, Tatarelli, De } \\
\text { Pisa, \& Girardi, } 2008\end{array}$ & 150 psychiatric patients & $2-3-7-8-10$ \\
\hline & 30 & Zagar, Kovach, Basile, Grove, Hughes, et al., 2013 & $\begin{array}{l}236 \text { patients, prisoners, students, } \\
\text { workers, } 2 \text { suicide completers, } 58 \\
\text { substance abusing }\end{array}$ & $\begin{array}{l}\text { SP Beck 2-4-6-8-AAS } \\
\text { (ACK) overdose \& } \\
\text { suicide }\end{array}$ \\
\hline & 31 & $\begin{array}{l}\text { Pompili, Innamorati, Di Vittorio, Baratta, Massotti, } \\
\text { Badaracco, Wond, Lester, Yip, Girardi, \& Amore, } \\
2014\end{array}$ & $\begin{array}{l}245 \text { suicide completers, } 41 \\
\text { psychiatric outpatients no ideation, } \\
286 \text { total }\end{array}$ & 6 , unemployment \\
\hline & 142 & & 128,435 & \\
\hline
\end{tabular}


Table 2a. 70 Teen and Adult Probation-Parole Decision-Making Tests including the SP: Teens (1 of 5)

\begin{tabular}{lclcccccl}
\hline Author & Time & Place & Tracked & $n$ & Controls & Gender & Items & Analyses \\
\hline Monachesi & 1932 & Minneapolis & 3 & 896 & no & M,F & 43 & unit* \\
Jenkins, et al. & 1942 & New York & 2 & 226 & no & M & 45 & unit* $^{*}$ \\
Jenkins, et al. & 1942 & New York & 2 & 300 & no & M & 95 & unit* $^{*}$ \\
Weeks & 1943 & Washington & 2 & 840 & no & M & 14 & unit* \\
Glueck \& Glueck & 1950 & Boston & 10 & 500 & yes & M & 5 & regression \\
Simon & 1956 & London & 5 & 1,121 & no & M & 4 & unit* phi=.16-.17 r=.17 \\
U.S. Navy & 1959 & San Diego & 2 & 20,000 & no & M & 20 & unit* \\
McClintock & 1961 & London & 2 & 1,449 & no & M & 6 & unit* \\
Mannheim et al & 1955 & London & 6 & 385 & no & M & 5 & regression phi=.46-.5 \\
Wenk, et al. & 1972 & Sacramento & 2 & 4,146 & no & M & 6 & unit* \\
Kandel, et al. & 1989 & Denmark & 10 & 265 & no & M,F & 1 & unit* ROC=.67 \\
Zagar \& Grove & 2010 & Chicago & 10 & 1,122 & Yes & M,F & 14 & AUC=.91 \\
Zagar, et al. & 2013 & Chicago & 10 & 236 & Yes & M,F & 14 & Sensitivity specificity.97 \\
Summary: & & 2 Continents & $2-10$ & 31,581 & yes & M,F & $4-116$ & \\
\hline
\end{tabular}

Note. - Only Zagar and Grove 2010 and Zagar et al., 2013 used random sampling. All participants were adolescents. *Unit = refers to the actuarial approach to parole decision making that involves a univariate comparison to reoffending outcome statistic developed by Burgess (1928) and improved by Nuffield (1982) and Quinsey, et al. (1998). $\mathrm{M}=$ male, $\mathrm{F}=$ female. ROC= receiver operating characteristic (which is roughly equivalent to the $A U C$ or area under the curve), $a=$ alpha; $p t b=$ point bi-serial; base exp. =base expectancy; regress. =regression; discrim. = discriminant analysis; $b=$ beta coefficient; sensitivity = identifying the re-offender precisely; specificity is not over identifying someone as an offender.

Table 2b. 70 Teen and Adult Probation-Parole Decision-Making Tests including the SP: Adults (2 of 5)

\begin{tabular}{|c|c|c|c|c|c|c|c|}
\hline Author & Time & Place & Tracked (yr.) & $n$ & Gender & Items & Analysis \\
\hline Warner & 1923 & Boston & 2 & 680 & M & 15 & unit* \\
\hline Borden & 1928 & Trenton & 1 & 263 & M & 28 & unit* \\
\hline Burgess & 1928 & Chicago & 3 & 3,000 & M & 21 & unit* \\
\hline Burgess & 1929a,b & Chicago & 2 & 263 & M & 26 & unit* \\
\hline Vold & 1930 & Minneapolis & 6 & 290 & M & 14 & unit* $\boldsymbol{r}$ offense \\
\hline Vold & 1931 & Chicago & 6 & 1,192 & M & 14 & unit* $.1-.3$ \\
\hline Tibbits & 1931 & Minneapolis & 7 & 3,000 & $\mathrm{M}, \mathrm{F}$ & 24 & unit* \\
\hline Monachesi & 1932 & Minneapolis & 3 & 619 & M & 34 & unit* \\
\hline Van Vechten & 1933 & Chicago & 2 & 564 & M & 21 & unit* \\
\hline Vold & 1935 & Boston & 6 & 1,158 & M & 10 & unit* \\
\hline Redden & 1939 & Chicago & 2 & 10,210 & M & 21 & unit* \\
\hline U.S. Attorney General & 1939 & Washington, DC & 2 & 53,033 & M & 10 & unit* \\
\hline Gillin & 1943 & Wisconsin & 2 & 1,000 & M & 15 & unit* \\
\hline Hakeem & 1948 & Chicago & 10 & 1,861 & M & 23 & regression $r=.31$ \\
\hline Hakeem & 1948 & Chicago & 3 & 9,729 & M & 23 & regression \\
\hline Ohlin \& Duncan & 1949 & Chicago & 5 & 5,624 & M & 27 & unit* \\
\hline Ohlin & 1951 & Chicago & 5 & 4,941 & M & 12 & unit* \\
\hline Glaser & 1962 & Chicago & 3 & 2,637 & M & 7 & unit* \\
\hline Metzner \& Weil & 1963 & Boston & 2.5 & 311 & M & 12 & base expect. \\
\hline Metzner \& Weil & 1963 & Boston & 2.5 & 311 & M & 16 & unit* \\
\hline Babst \& Mannering & 1965 & Wisconsin & 5 & 7,614 & M & 3 & base expect. \\
\hline Vikert \& Zahnd & 1965 & Ontario & 2 & 200 & M & 3 & base expect. \\
\hline Carney & 1967 & Boston & 4 & 363 & $\mathrm{M}$ & 2 & unit* \\
\hline Ward & 1968 & Sydney & 7 & 2,065 & M & 14 & $\begin{array}{l}\text { unit* } r=.44 \text { regression } \\
\text { discr. base except. }\end{array}$ \\
\hline Walker \& McCabe & 1973 & London & 6 & 100 & $\mathrm{~F}$ & 3 & unit* regression $b=.1$ \\
\hline
\end{tabular}

Note. - Only Zagar and Grove 2010 and Zagar et al., 2013 used random sampling. All participants were adolescents. *Unit $=$ refers to the actuarial approach to parole decision making that involves a univariate comparison to reoffending outcome statistic developed by Burgess (1928) and improved by Nuffield (1982) and Quinsey, et al. (1998). $\mathrm{M}=$ male, $\mathrm{F}=$ female. $R O C=$ receiver operating characteristic (which is roughly equivalent to the $A U C$ or area under the curve), $a=$ alpha; $p t b=$ point bi-serial; base exp. =base expectancy; regress. =regression; discrim. = discriminant analysis; $b=$ beta coefficient; sensitivity = identifying the re-offender precisely; specificity is not over identifying someone as an offender. 
Table 2c. 70 Teen and Adult Probation-Parole Decision-Making Tests including the SP: Adults (3 of 5)

\begin{tabular}{|c|c|c|c|c|c|c|c|}
\hline Author & Time & Place & Tracked & $n$ & Gender & Items & Analyses \\
\hline Walker \& McCabe & 1973 & London & 6 & 351 & M & 3 & unit* \\
\hline Walker \& McCabe & 1973 & Ontario & 6 & 423 & M & 3 & unit* \\
\hline Carlson & 1973 & Ontario & 5 & 1,070 & M & 7 & unit* \\
\hline Challinger & 1974 & Melbourne & 2 & 593 & M & 25 & unit* \\
\hline Hoffman \& Beck & 1974 & Washington, DC & 2 & 2,483 & M & 9 & $p t b=.32, R O C=.69$ \\
\hline Ferguson, et al. & 1975 & Wellington & 2 & 1,000 & M & 25 & regression $p h i=1$ \\
\hline Quinsey, et al. & 1975 & Toronto & 4 & 60 & M & 5 & unit* \\
\hline Hoffman \& Beck & 1976 & Washington, DC & 2 & 1,011 & M & 9 & $p t b=.32, R O C=.69$ \\
\hline Nuttall & 1977 & London & 3 & 1,138 & M & 16 & unit* \\
\hline Gottfredson, et al. & 1978 & Washington, DC & 2 & 2,483 & M & 9 & unit $* p t b=.28$ \\
\hline Hoffman \& Beck & 1980 & Washington, DC & 3 & 1,000 & M & 8 & unit* \\
\hline Soothill, et al. & 1980 & London & 5 & 166 & M & 3 & unit* \\
\hline Greenwood & 1982 & $\begin{array}{l}\text { California } \\
\text { Michigan } \\
\text { Texas }\end{array}$ & 2 & 781 & M & 7 & unit* \\
\hline Holland, et al. & 1982 & California & 2.5 & 198 & M & 1 & unit* \\
\hline Nuffield & 1982 & Ottawa & 3 & 2,500 & M & 13 & $\begin{array}{l}\text { unit* } R O C=.69 \\
\text { (violent) regression discr. }\end{array}$ \\
\hline Nuffield & 1982 & Ottawa & 3 & 2,500 & M & 15 & $\begin{array}{l}\text { unit* } R O C=.69 \\
\text { regression }\end{array}$ \\
\hline Hoffman & 1983 & Washington, DC & 3 & 5,237 & M & 6 & unit* $R O C=.69$ \\
\hline \multirow[t]{2}{*}{ Steadman } & 1983 & Massachusetts & 5 & 393 & M & 37 & unit* \\
\hline & & Pennsylvania & & & & & \\
\hline
\end{tabular}

Note. - Only Zagar and Grove 2010 and Zagar et al., 2013 used random sampling. All participants were adolescents. *Unit = refers to the actuarial approach to parole decision making that involves a univariate comparison to reoffending outcome statistic developed by Burgess (1928) and improved by Nuffield (1982) and Quinsey, et al. (1998). M = male, $\mathrm{F}=$ female. ROC= receiver operating characteristic (which is roughly equivalent to the $A U C$ or area under the curve), $a=$ alpha; $p t b=$ point bi-serial; base exp. =base expectancy; regress. =regression; discrim. = discriminant analysis; $b=$ beta coefficient; sensitivity = identifying the re-offender precisely; specificity is not over identifying someone as an offender.

Table 2d. 70 Teen and Adult Probation-Parole Decision-Making Tests including the SP: Adult (4 of 5)

\begin{tabular}{|c|c|c|c|c|c|c|c|}
\hline Author & Time & Place & Tracked (yr.) & $n$ & Gender & Items & Analyses \\
\hline Bonta \& Motiuk & 1985 & Ottawa & 2 & 164 & M & 58 & Unit* $\mathbf{a}=.72, r=.87-.99$ \\
\hline Goldkamp \& Gottfredson & 1985 & Sacramento & 8 & 937 & M & 7 & Unit* \\
\hline Andrews, et al. & 1986 & Ottawa & 3 & 192 & M & 58 & Unit* \\
\hline Goldkamp, et al. & 1988 & $\begin{array}{l}\text { Arizona } \\
\text { Massachusetts } \\
\text { Florida }\end{array}$ & & 9,090 & M & 9 & Regression \\
\hline Gottfredson \& Gottfredson & 1988 & Sacramento & 8 & 1,810 & M & 7 & Base exp. $p t b=.3$ \\
\hline Klassen \& O'Connor & 1988 & Kansas City & 1 & 304 & M & 64 & Umt* \\
\hline $\begin{array}{l}\text { Jones } \\
\text { Jones \& Goldkamp }\end{array}$ & $\begin{array}{l}1991 \\
1991\end{array}$ & $\begin{array}{l}\text { Kansas } \\
\text { Miami }\end{array}$ & $\begin{array}{l}3 \\
5\end{array}$ & $\begin{array}{l}1,140 \\
5,470\end{array}$ & $\begin{array}{l}M \\
M\end{array}$ & $\begin{array}{r}18 \\
7\end{array}$ & $\begin{array}{l}\text { Unit"' } \\
\text { Unit* }\end{array}$ \\
\hline Harris, et al. & 1993 & San Antonio & 1.5 & 396 & M & 71 & Unit* \\
\hline Bonta, et al. & 1996 & Ottawa & 3 & 3,267 & M & 8 & Unit* \\
\hline Quinsey, et al. & 1998 & Ottawa & 10 & 600 & M & 13 & Unit* $R O C=.76$ discr. \\
\hline Quinsey, et al. & 1998 & Ottawa & 10 & 200 & M & 15 & Unit* $R O C=.10$ discr. \\
\hline $\begin{array}{l}\text { Kassenbaum, et al. } \\
\text { Summary: }\end{array}$ & $\begin{array}{l}2001 \\
78 \mathrm{yr} .\end{array}$ & Honolulu & $\begin{array}{c}2 \\
1-10\end{array}$ & $\begin{array}{r}314 \\
154,956\end{array}$ & $\begin{array}{l}\text { M } \\
\text { M.F }\end{array}$ & $\begin{array}{c}12 \\
1-71\end{array}$ & $\begin{array}{l}\text { Unit* } \\
\text { Unit* } a, r, p t b, \text { discr. } \\
\text { Base exp., } R O C\end{array}$ \\
\hline
\end{tabular}

Note. - Only Zagar and Grove 2010 and Zagar et al., 2013 used random sampling. All participants were adolescents. *Unit = refers to the actuarial approach to parole decision making that involves a univariate comparison to reoffending outcome statistic developed by Burgess (1928) and improved by Nuffield (1982) and Quinsey, et al. (1998). $\mathrm{M}=$ male, $\mathrm{F}=$ female. $R O C=$ receiver operating characteristic (which is roughly equivalent to the $A U C$ or area under the curve), $a=$ alpha; $p t b=$ point bi-serial; base exp. =base expectancy; regress. =regression; discrim. = discriminant analysis; $b=$ beta coefficient; sensitivity = identifying the re-offender precisely; specificity is not over identifying someone as an offender. 


\section{7-Point Violence Profile in Homicidal, Overdosing-Substance-Abusing, Sex-Offending \&Suicide-Completers}

Table 2d. Summary of 320,051 Homicidal, Overdosing, Sex-Offending, Suicidal, \& Offenders in 212 Studies Confirming a "7-Point Violence Profile" (5 of 5)

\begin{tabular}{|c|c|c|c|c|c|c|}
\hline At-Risk & Tests Used & \# of Studies & \# of Persons & Years & & "7-Point Violence Profile" \\
\hline Homicidal-Violent-Prone & $\begin{array}{l}\text { MMPI, } \quad \text { MMPI-2, } \\
\text { MMPI-A }\end{array}$ & 44 & 21,130 & $1949-2014$ & 65 & "F/L-2(D)-4(Pd)-6(Pa)-8(Sc)" \\
\hline Overdosing-Substance-Abusing & $\begin{array}{l}\text { MMPI, } \\
\text { MMPI-A }\end{array}$ & 21 & 66,839 & $1984-2017$ & 43 & $\begin{array}{l}\text { "F/L-2(D)-4(Pd)-6 } \\
(\mathrm{Pa})-8(\mathrm{Sc})-\mathrm{AAS}(\mathrm{PRO}) "\end{array}$ \\
\hline Sex-Offending & $\begin{array}{l}\text { MMPI, } \quad \text { MMPI-2, } \\
\text { MMPI-A }\end{array}$ & 45 & 9,832 & $1971-2018$ & 47 & "F/L-2(D)-4(Pd)-6(Pa)-8(Sc)" \\
\hline Suicide-Completers & $\begin{array}{l}\text { MMPI, } \quad \text { MMPI-2, } \\
\text { MMPI-A }\end{array}$ & 31 & 30,634 & $1958-2014$ & 64 & "F/L-2(D)-4(Pd)-6(Pa)-8(Sc)" \\
\hline Delinquents (Teens) & $\begin{array}{l}\text { Standard Predictor } \\
(\mathrm{SP}) \text { of Violence } \\
\text { Potential \& other tests }\end{array}$ & 13 & 31,486 & $1932-2013$ & 81 & $\begin{array}{l}\text { High Standard Predictor of } \\
\text { Violence Potential or other } \\
\text { test scores }\end{array}$ \\
\hline Criminals (Adults) & $\begin{array}{l}\text { Standard Predictor of } \\
(\mathrm{SP}) \quad \text { Violence } \\
\text { Potential \& other tests }\end{array}$ & 57 & 160,130 & $1923-2013$ & 90 & $\begin{array}{l}\text { High Standard Predictor of } \\
\text { Violence Potential or other } \\
\text { test scores }\end{array}$ \\
\hline Total & $\begin{array}{l}\text { MMPI, } \quad \text { MMPI-2, } \\
\text { MMPIA, SP, others }\end{array}$ & 212 & 320,051 & $1923-2018$ & 95 & $\begin{array}{l}\text { "F/L-2(D)-4(Pd)-6(Pa)- } \\
\text { 8(Sc)-AAS (PRO) \& SP" }\end{array}$ \\
\hline
\end{tabular}

A random subsample of 4,987 was obtained by using a random number table from these convenience samples of 50,000 people referred for assessment by courts, industry, hospitals, schools, and universities, and 5,000 delinquent and criminal court persons, This random subsample consisted of all cases with full test data since they were referred by the court, hospitals, industry or university for testing, and had complete examinations. Adults and youth without examinations or without full test data were excluded from the random subsample and comprised the larger population.

Then, these 4,987 adults and teens were randomly sampled with a random number table. Thus, the adult and teen study groups were a selection of 136 persons, which made up the five groups of homicidal, overdosing-substance-abusing, sex-offending, suicide-completer, and control adults and teens, making up ten study groups. This random selection had a goal of at least a minimum of ten and maximum of 25 , within each of the ten study groups. Summarizing, there were two sets of study groups, five adult and five teen (homicidal, overdosing-substance-abusing, sex-offending, suicide-completers, and controls) that made up the ten study groups in this random subsample.

\subsubsection{Demographics of Random Subsample of Combined Adult and Teen Study Groups}

The combined adult and teen study group demographics were $N=136$ persons with 98 males (72\%) and 38 females $(28 \%)$. The $M$ age $=28.68$ with the $S D=8.33$ yr. The $M$ education $=12.71$ with the $S D=2.15 \mathrm{yr}$., or some college. There were 36 Euro-Americans (26\%), 71 African-Americans (52\%), 19 Hispanic-Americans (14\%), and 10 others (Asian, Filipino, or Native American Indian) [8\%]. The combined adult and teen family composition was 8 orphans (6\%), 71 one parent families (52\%), 14 step-parents (10\%), and 43 mother + father families (32\%). Of the 136 participants, approximately 20 or $15 \%$ traveled in for the examinations from adjoining states of Indiana, Michigan, Minnesota, Wisconsin, and New Jersey, and were referred by airlines, courts, energy production industries, insurance firms, trucking companies, and lawyers.

\subsubsection{Demographics of a Random Subsample of Adult Study Groups}

The adult study groups demographics include $n=79$ individuals, with 56 men (71\%) and 23 women (29\%). The $M$ age $=38.29$ with the $S D=12.40$ yr. The $M$ education $=15.08$ with the $S D=2.68$ yr., or some college. There were 21 Euro-Americans (27\%), 42 African-Americans (53\%), 11 Hispanic-Americans (14\%) and 5 others (Asian, Filipino or Native American Indian) [6\%]. The family composition was 3 orphans (4\%), 40 single parents (51\%), 8 step-parents $(10 \%)$ and 28 mother + father families $(38 \%)$. 
This adult subsample study groups included some people most at-risk for violence, including those with issues related to alcoholism, assault, autism, behavior and emotional school disturbance, career delinquency or criminality, cognitive delay, credibility issues, such as facetiousness and malingering, divorce or separation, domestic violence, hyperactivity, lack of work skills, learning disability, physical, sex-offending or homicidal tendencies, marital challenges, mental illness, pedophilia, post-chemotherapy, sexual or verbal abuse, school dropout, somatoform disorders, substance addiction, suicide attempt or ideation, underachievement, and vocational guidance. The referrals were for competence to stand trial, developmental disability, hearing, motor, speech, or visual challenges, employment hiring, promotion or termination, high school, college, graduate school or seminary entrance, local, national or international adoption, parole or probation hearings, physical or personal injury, pre-sentencing, pre-trial, travel with pet on airlines, and workers compensation issues.

Selection of referrals for the adult study groups is similar to the selection of the standardization samples for the MMPI-2/A and other personality and ability tests, which are basically convenience samples from clinical and school professionals recruited by the testing corporations, who along with volunteer test subjects are chosen to meet certain age, gender, race, socio-economic status (SES) and specialized population characteristics, and are given a small stipend to take the test. This is the same as court, hospital, industry or insurance referrals, who pay for the examination and report. SES was measured by family annual income, in 2010 dollars, with a national median of $\$ 71,900$ (U.S. Census Bureau, 2018). Low SES consisted of incomes from $\$ 0$ to $\$ 30,000$, and middle SES from $\$ 30,001$ to $\$ 100,000$.

\subsection{Adult Study Groups}

There were five study groups of adults: (1) homicidal; (2) overdosing-substance-abusing; (3) sex-offending; (4) suicide-completers; and (5) controls ( $n=79)$. See Table 3a.

\subsection{Adult Homicidal Study Group}

Among the twelve homicidal adults there were nine men and three women. The $M$ age $=39.23$ and the $S D=9.36 \mathrm{yr}$, or middle age. They had $M$ education $=15.38$, and the $S D=2.06$ yr., or some college. There were three Euro-Americans (25\%), six African-Americans (50\%), two Hispanic-Americans (17\%) and one other (Asian, Filipino, or Native American Indian) [8\%]. Occupations included professional coach, electric station controller, firefighter, handyman, mechanic, physician, police officer, port shipping supervisor, programmer, rabbi, sales person, and teacher with Army, Marines and Navy veterans. "Homicide" is defined as adjudication and conviction before a judge in court for killing of another individual(s), and by Illinois state law.

\subsection{Adult Overdosing-Substance-Abusing Study Group}

Among the thirteen overdosing-substance-abusing adults, there were nine men and four women. The $M$ age $=38.29, S D$ $=12.40$ yr., or middle age. The $M$ education $=15.08$ and the $\mathrm{SD}=2.68 \mathrm{yr}$., or some college. There were three EuroAmericans (23\%), seven African-Americans (54\%), two Hispanic-Americans (15\%) and one other (Asian, Filipino, or Native American Indian) [8\%]. Occupations included college coach, finance manager, football professional, lawyer, physician, pilot, policeman, professor, rabbi, refinery supervisor, scout leader, train engineer, and truck driver with Army, Coast Guard and Navy veterans.

Overdosing-substance-abusing is weekly alcohol abuse, substance-abuse, and alcohol and substance-abuse such as amphetamines, aromatics (paint or glue) barbiturates, cocaine, fetal polysubstance-abuse history, hallucinogens, heroin, glue sniffing, marijuana, nicotine, opiates, PCP and other substances. Many were hospitalized, either as an inpatient or outpatient, following an episode of loss of consciousness. Some died. Suicide conformed with the definition in the Diagnostic Statistical Manual-Fifth Edition [DSM-V] (American Psychiatric Association, 2013) and the International Classification of Diseases [ICD-10] (World Health Organization, 2013): and the state of Illinois statutes. Suicide completers died. Suicide attempters had a documented police report of a suicide attempt, along with hospital medical records. Suicide ideation was recorded court, medical, school or work record to suicide intentions and ideation discussed and reported.

\subsection{Adult Sex-Offending Study Group}

Among the fifteen persons, there were ten men and five women. They had $M$ age $=36.07$ and the $S D=11.03$ yr., or middle age. The $M$ education $=15.53$ and the $S D=3.17$ yr., or some college. There were four Euro-Americans $(27 \%)$, eight African-Americans (53\%), two Hispanic-Americans (14\%) and one other (Asian, Filipino, or Native American Indian) [6\%]. Occupations included Olympic coach, construction worker, firefighter, mechanic, minister, nurse, physician, policeman, priest, professor, professional baseball player, restaurant waiting, sales, speech therapist, and teacher, including Air Force, Army and Navy veterans.

Sex-offending was molestation, pedophilia or rape, and by operational definition was identified and convicted individuals, who had raped a female or male, with evidence presented in court, and met the criterion for rape or 
aggravated criminal sexual assault as defined in Illinois laws. By definition, a "sexual molester" was an identified, detected, and convicted individual who molested a minor, supported by evidence presented in court. "Molestation" "pedophilia" and "rape" were consistent with the definition of pedophilia in the Diagnostic Statistical Manual-Fifth Edition (DSM-V; American Psychiatric Association, 2013) and the International Classification of Diseases Tenth Edition (World Health Organization, 2013).

\subsection{Adult Suicide-Completer Study Group}

Among fifteen individuals, there were ten men and five women. The $M a \mathrm{ge}=34.20$ and the $S D=11.09 \mathrm{yr}$. or middle age; The $M$ education $=14.20$ and the $S D=2.65$ yr., or some college. There were four Euro-Americans (27\%), eight African-Americans (53\%), two Hispanic-Americans (14\%) and one other (Asian, Filipino, or Native American Indian) [6\%]. Occupations included bookkeeper, Buddhist monk, bus driver, delivery person, doctor, emergency medical technician, judge, lawyer, minister, nuclear plant controller, nurse, pilot, policeman, priest, and stewardess with Army, Marine and Navy veterans, and one special-forces military. Suicide completion was death by one's own hand, consistent Diagnostic Statistical Manual-Fifth Edition (DSM-V); American Psychiatric Association, 2013, and the International Classification of Diseases Tenth Edition (World Health Organization, 2013), and Illinois laws.

\subsection{Adult Control Study Group}

Among 24 persons, there were 18 men and six women. The $M$ age $=41.75, S D=14.67 \mathrm{yr}$. The $M$ education $=16.00$ and the $S D=1.89$ yr., or a college degree. There were seven Euro-Americans (29\%), thirteen African-Americans (54\%), three Hispanic-Americans (12\%) and one other (Asian, Filipino, or Native American Indian) [5\%]. Occupations included bookkeeper, bus driver, college track coach, emergency medical technician, engineer, firefighter, finance manager, golf professional, minister, nurse, Olympic athlete, occupational therapist, payroll personnel, physical therapist, pilot, police woman, priest, programmer, psychiatrist, rabbi, scout leader, stewardess, train engineer, and university volleyball champion with Air Force, Army, Coast Guard, Marine, and Navy veterans. The control group comprised inpatient and out-patients referred to hospital, industry, and university clinics from 1992 to 2018, by health care workers. Part or full time and summer work included babysitting, car washing, cashier, coding, cooking, delivery, dishwashing, farming, housekeeping, janitor, landscaping, nanny, painting, restaurant work, sales, snow removal and volunteering at nonprofit and religious organizations.

\subsection{Teen and Teen Homicidal Study Groups}

There were five teen study groups: (1) homicidal; (2) overdosing-substance-abusing; (3) sex-offending; (4) suicide-completers; and (5) controls $(n=57)$. The teen study group demographics were: $\mathrm{N}=57$ youth with 42 boys ( $74 \%)$ and 15 girls $(26 \%) ; \mathrm{M}$ age $=15.37, \mathrm{SD}=1.41 \mathrm{yr}$.; $\mathrm{M}$ education $=9.44$, S.D. $=1.41 \mathrm{yr}$., or some high school. There were 15 Euro-Americans (26\%), 29 African-Americans (51\%), eight Hispanic-Americans (14\%), and five other (Asian, Filipino, or Native American Indian) [9\%]. The family composition was five orphans (9\%), 31 single parents (54\%), six step-parents $(11 \%)$ and 15 mother + father families (26\%). Part or full time, and summer work included babysitting, car washing, cashier, coding, cooking, delivery, dishwashing, farming, housekeeping, janitor, landscaping, nanny, painting, restaurant work, sales, snow removal and volunteering at nonprofit and religious organizations. See Table $3 b$.

Among the eleven homicidal teens, there were ten boys and one girl. The $M$ age $=16.19$ with the $S D=0.87 \mathrm{yr}$. The $M$ education $=9.27$ with the $\mathrm{SD}=1.35 \mathrm{yr}$., or some high school. There were three Euro-Americans $(27 \%)$, five African-Americans (45\%), two Hispanic-Americans (18\%) and one other (Asian, Filipino, or Native American Indian) [10\%]. "Homicide" is defined as adjudication and conviction before a judge in court, and by Illinois state law.

\subsection{Teen Overdosing-Substance-Abusing Study Group}

Among seven overdosing teens, there were five boys and two girls. The $M$ age $=13.71$ with the $S D=1.60 \mathrm{yr}$. The $M$ education $=8.28$ with the $S D=1.60$ yrs., or beginning high school. There were two Euro-Americans $(29 \%)$, three African-Americans (43\%), one Hispanic-American (14\%) and one other (Asian, Filipino, or Native American Indian) [14\%]. Overdosing-substance-abusing is weekly alcohol abuse, substance-abuse, and alcohol and substance-abuse with the definition in the Diagnostic Statistical Manual-Fifth Edition [DSM-V] (American Psychiatric Association, 2013) and the International Classification of Diseases [ICD-10] (World Health Organization, 2013), and Illinois state law.

\subsection{Teen Sex-Offending Study Group}

Among ten sex-offending teens, there were nine boys and one girl. The $M$ age $=15.40$ with the SD $=0.84$ yr. The $M$ education $=9.20$ with the $\mathrm{SD}=0.63 \mathrm{yr}$, or some high school. There were three Euro-Americans (30\%), five African-Americans (50\%), two Hispanic-Americans (20\%) and one other (Asian, Filipino, or Native American Indian) [10\%]. The same operational definition of sex-offending adults applies for sex-offending teens except the place of adjudication and conviction may be in juvenile or family court. 
Sex-offending was molestation, pedophilia or rape and by operational definition were identified and convicted individuals who had raped a female or male, with evidence presented in court, and met the criterion for rape or aggravated criminal sexual assault as defined in Illinois laws. By definition, a "sexual molester" was an identified, detected, and convicted individual who molested a minor, supported by evidence presented in court. "Molestation" "pedophilia" and "rape" were consistent with the definition of pedophilia in the Diagnostic Statistical Manual-Fifth Edition (DSM-V), the American Psychiatric Association, 2013 and the International Classification of Diseases Tenth Edition (World Health Organization, 2013).

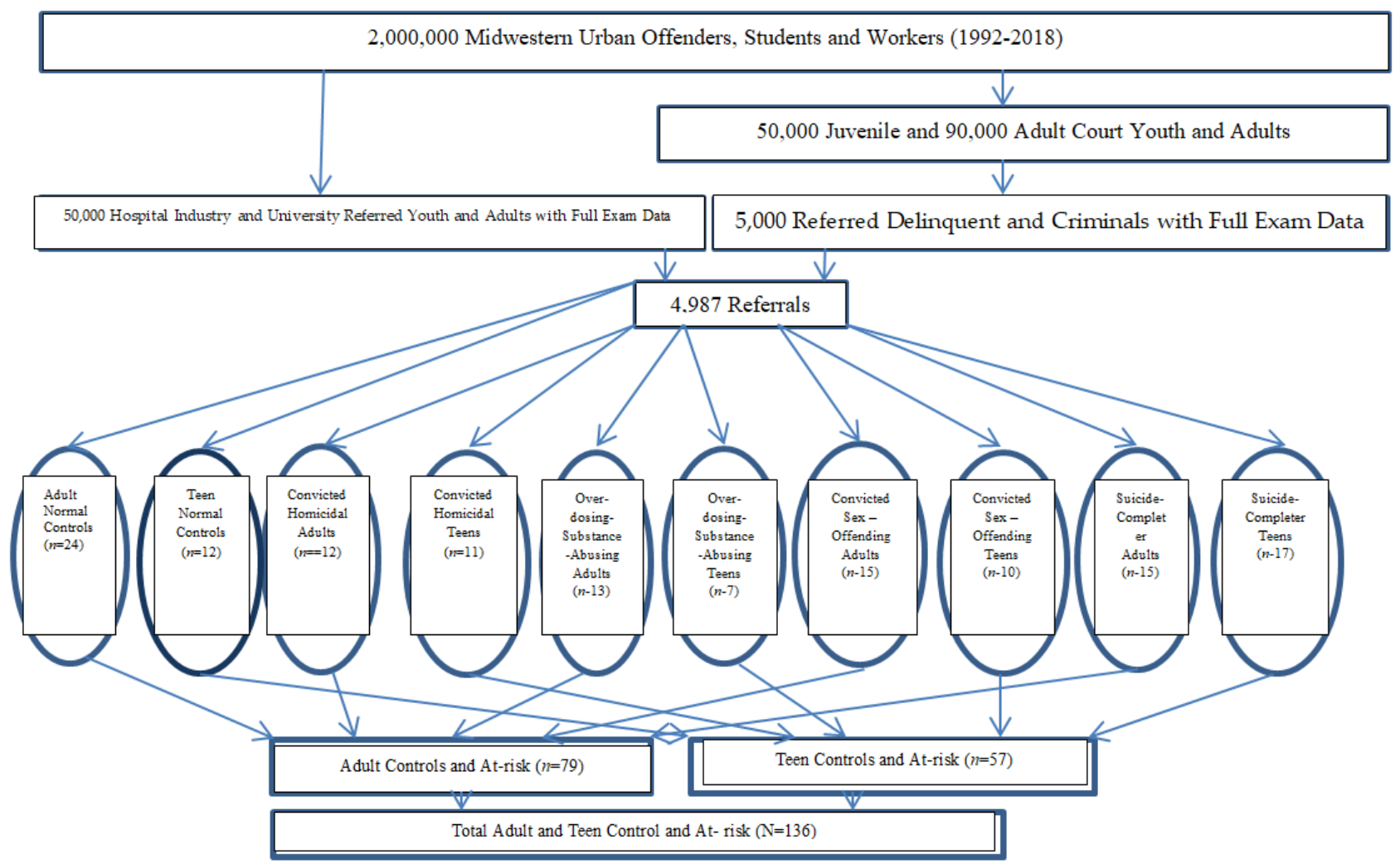

Figure 3. Population \& Sample Selection: Homicidal, Overdosing, Sex-Offending, Suicidal, Adults \& Teens $(N=136)$

\subsection{Teen Suicide-Completer Study Group}

Among 17 suicide-completing teens, there were ten boys and seven girls. The $M$ age $=15.12$ with the $S D=1.59 \mathrm{yr}$. The $M$ education $=9.27$ with the $S D=1.35$ yr., or some high school. There were four Euro-Americans $(24 \%)$, ten African-Americans (59\%), two Hispanic-Americans (12\%), and one other (Asian, Filipino, or Native American Indian) [5\%]. Suicide completion is death by one's own hand consistent Diagnostic Statistical Manual-Fifth Edition (DSM-V; American Psychiatric Association, 2013), the International Classification of Diseases Tenth Edition (World Health Organization, 2013), and Illinois law.

\subsection{Teen Control Study Group}

Among 12 control teens, there were six boys and six girls. The $\mathrm{M}$ age $=15.91, \mathrm{SD}=1.56 \mathrm{yr}$., The $\mathrm{M}$ education $=10.08$, $\mathrm{SD}=1.68$ yrs., or some high school. There were three Euro-Americans (25\%), six African-Americans (50\%), two Hispanic-Americans (17\%) and one other (Asian, Filipino, or Native American Indian) [8\%]. Controls were randomly selected from 50,000 clinic-referred youth and adults. Referrals were for developmental, hearing, learning, motor, speech, visual, or other issues to assess level of function for interventions, schooling, or treatment.

\subsection{Combined, Adult and Teen Study Groups' Characteristics Compared with U.S. and E.U. Populations}

Given (1977) showed that murder rates among groups as diverse as $13^{\text {th }}$-century Englishmen; $19^{\text {th }}$-century Euro-American gold miners in Colorado, California, and Alaska, Hispanics in urban Mexico City, Caracas, and Bogota; Asians in urban Hong Kong and Tokyo, and $21^{\text {st }}$ U.S. and E.U. populations, were the same. These groups can be tentatively assumed to be representative of the U.S. and E.U. population demographics. 
Table 3a. Demographics Adult and Teen, Adult, Teen: At-Risk Groups with U.S. E.U. Population and $X^{2}$

\begin{tabular}{|c|c|c|c|c|c|}
\hline Demographic & $\begin{array}{l}\text { U.S. } \\
\text { Population }\end{array}$ & Group & $X^{2}$ & $\begin{array}{l}\text { E.U. } \\
\text { Population }\end{array}$ & $X^{2}$ \\
\hline \multicolumn{6}{|l|}{$\begin{array}{l}\text { Combined Adults + } \\
\text { Teens }(N=136)\end{array}$} \\
\hline Boy-Girl Ratio & $48-52^{\mathrm{a}}$ & $72-28$ & N.S. & $45-55^{\mathrm{c}}$ & $29.45^{*}$ \\
\hline $\begin{array}{l}\text { Race-Ethnicity } \\
\text { Ratio: } \\
\text { African-American }\end{array}$ & $31^{\mathrm{b}}$ & 52 & $24.77 *$ & & \\
\hline Euro-American & $54^{\mathrm{b}}$ & 26 & & & \\
\hline Hispanic American & $12^{\mathrm{b}}$ & 14 & & & \\
\hline $\begin{array}{l}\text { Other (Asian, } \\
\text { Filipino, Native } \\
\text { American Indian) }\end{array}$ & $3^{\mathrm{b}}$ & 8 & & & \\
\hline $\begin{array}{l}\text { Family Ratio } \\
\text { Orphan }\end{array}$ & $4^{\mathrm{b}}$ & 8 & & $3^{\mathrm{d}}$ & \\
\hline Single Parent & $27^{\mathrm{b}}$ & 52 & & $12 \mathrm{~d}$ & \\
\hline Step Parent & $10^{\mathrm{b}}$ & 14 & & $6^{\mathrm{d}}$ & \\
\hline Mother + Father & $59^{\mathrm{b}}$ & 32 & & $77^{\mathrm{d}}$ & \\
\hline \multicolumn{6}{|l|}{ Adults $(n=79)$} \\
\hline Boy-Girl Ratio & $48-52^{\mathrm{a}}$ & $71-29$ & N.S. & $45-55^{\mathrm{c}}$ & $27.31 *$ \\
\hline $\begin{array}{l}\text { Race-Ethnicity Ratio } \\
\text { African-American }\end{array}$ & $31^{\mathrm{b}}$ & 53 & $21.38 *$ & & \\
\hline Euro-American & $54^{\mathrm{b}}$ & 27 & & & \\
\hline Hispanic American & $12^{\mathrm{b}}$ & 14 & & & \\
\hline $\begin{array}{l}\text { Other (Asian, } \\
\text { Filipino, Native } \\
\text { American Indian) }\end{array}$ & $3^{\mathrm{b}}$ & 6 & & & \\
\hline $\begin{array}{l}\text { Family Ratio } \\
\text { Orphan }\end{array}$ & $4^{b}$ & 4 & & $3^{\mathrm{d}}$ & 135.98* \\
\hline Single Parent & $27^{\mathrm{b}}$ & 51 & & $12^{\mathrm{d}}$ & \\
\hline Step Parent & $10^{\mathrm{b}}$ & 10 & & $6^{\mathrm{d}}$ & \\
\hline Mother + Father & $59^{\mathrm{b}}$ & 35 & & $77^{\mathrm{d}}$ & \\
\hline \multicolumn{6}{|l|}{ Teens $(n=57)$} \\
\hline Boy-Girl Ratio & $48-52^{\mathrm{a}}$ & $74-26$ & N.S. & $45-55^{\mathrm{c}}$ & $35.97 *$ \\
\hline $\begin{array}{l}\text { Race-Ethnicity Ratio } \\
\text { African-American }\end{array}$ & $31^{\mathrm{b}}$ & 57 & $36.02 *$ & & \\
\hline Euro-American & $54^{\mathrm{b}}$ & 26 & & & \\
\hline Hispanic American & $12^{\mathrm{b}}$ & 14 & & & \\
\hline $\begin{array}{l}\text { Other (Asian, } \\
\text { Filipino, Native } \\
\text { American Indian) }\end{array}$ & $3^{\mathrm{b}}$ & 9 & & & \\
\hline $\begin{array}{l}\text { Family Ratio } \\
\text { Orphan } \\
\end{array}$ & $4^{b}$ & 9 & N.S. & $3^{\mathrm{d}}$ & 263,21 \\
\hline Single Parent & $27^{\mathrm{b}}$ & 54 & & $12 d$ & \\
\hline Step Parent & $10^{\mathrm{b}}$ & 11 & & $6^{\mathrm{d}}$ & \\
\hline Mother + Father & $59^{\mathrm{b}}$ & 26 & & $77^{\mathrm{d}}$ & \\
\hline
\end{tabular}

In the U.S. Census Bureau, the United Nations Economic Commission, Statistical Yearbook of the Economic Commission of Europe, Trends in Europe and North America, the U.S. Department of Justice, Juvenile Offenders and 
Victims 2006 National Report, the National Longitudinal Survey of Youth, and the Demographic Research on the Diversity of Family Structure in Europe (Speder, 2005) records, the U.S. and E.U. gender, race/ethnicity, and family compositions were obtained. The purpose was to compare with the random samples of the combined adult and teen, the adult, and the teen homicidal, overdosing-substance-abusing, sex-offending, and suicide-completer, and controls with the U.S. and E.U. populations.

$X^{2}$ were computed to show that the U.S. and E.U. population and the study groups' demographics were similar. See Table 3a. The purpose of the comparisons was to give one an idea of the generalizability of the results. $X^{2}$ were calculated between the combined adults, and teens on gender ratios, race/ethnicity ratios and family composition ratios and the demographics of the overall populations of the U.S. and E.U. In summary, the study groups (combined, adults and teens) had more African Americans and fewer Euro-Americans, than the U.S. population.

Summing up, the study groups (combined, adults and teens) had more boys, more single parents, and fewer mother + father families, than the E.U. population. In the comparison, of the overall U.S. population and the combined adults and teens gathered in Cook County, Illinois for this study, the African-American ratio and the Euro-American ratio was significantly $(p<.01)$ different, i.e., in the general U.S. population, there were fewer African Americans, more Euro-Americans.

For the overall E.U. population compared to study group of combined adults and teens, the combined group were significantly $(p<.01)$ different, i.e., in the general E.U. population, there were fewer boys and more girls, and fewer single parents and more mother + father families. The majority of the significant comparisons were on demographics, which have been shown to be predictive of criminal behavior (homicide and sex-offending): gender ratio (most violent criminals are male), race/ethnicity (more risk factors, and thus, greater representation of minorities in violent criminal groups due to poverty), and broken families (since these family structures are risk factors for violence). Thus, there were no unexpected differences between the study groups of combined adults and teens, adults and teens and the general U.S. population.

\subsection{Measures: A Set of MLIT to Find Most At-Risk}

Several tests were chosen, after an exhaustive review of the research, on the sensitivity and the specificity of actuarial evaluations. Tests with high reliability and validity were chosen. A longer list of questions was thought to be required to achieve both sensitivity and specificity. There is considerable empirical literature attesting to the test-retest reliability of these tests in a variety of populations over time. A brief description of the selected tests follows, along with the data collection, decision making algorithm, statistics and experimental design. ${ }^{1}$

\footnotetext{
1 (F15a) Ammons Quick Test (QT) is a brief, norm-referenced assessment of receptive vocabulary, in a four-choice, picture format with three alternate forms, which takes five to 15 minutes to administer (Ammons and Ammons, 1962; Zagar et al., 2013). The QT was developed before the Peabody Picture Vocabulary Test (Dunn and Dunn, 1959; Vance and Singer, 1979; Dunn and Dunn, 1997), and is commonly used to screen in prisons for intellectual or learning disabilities. The QT can be employed with children through adults and has been used with patients, students, and employees (Mednick, 1969; Advokat, Eustis, and Pickering, 2005; Zagar, Kovach, Busch, Zablocki, Osnowitz, et al., 2013). (F15b) Beck Suicide Scale (BSS) is a 21-item test with three-choice format, which requires five minutes to complete. The BSS is intended to assess potential for suicide. The BSS uses self-descriptive statements on depression and suicide thoughts, like crying, failure, fatigue, guilt, insomnia, and irritability. This assessment also deals with pessimism, punishment, sadness, weight loss, and withdrawal and has a reliability and validity from .70 to .90 (Beck, 1978 , 1991). The BSS was given to 50 outpatients, and the correlation between their self-report of suicidal thoughts and independent clinicians rating suicidal ideation was .95 (Beck and Steer, 1981). Within a group of 25 outpatients, the Cronbach's alpha or coefficient of internal consistency was .97 (Beck, 1978; 1981). The 50 inpatients and 25 outpatients self-reports of suicidal thoughts were more severe, than the independent clinicians ratings of suicidal ideation (Beck, Steer, and Renairi, 1988). Among 50 inpatients, the correlation between self-reports of suicidal thoughts and independent clinician ratings of suicidal ideation was .96 (Beck, Kovacs, and Weisman, 1975). Among 90 suicidal (41 men, 59 women), the coefficient of internal consistency on the suicidal scale was .89 , while the correlation of self-reported suicidal thoughts and independent clinician ratings of suicidal ideation, was .83 (Beck, Kovacs and Weisman, 1979). The test-retest reliability was .41 (Beck and Lester, 1976). The best measure of the criterion of suicidal ideation is the one, which has the behaviors, which encompass the attributes of suicide (Beck, Resnik, and Lettieri, 1974; Beck, Morris, and Beck, 1974; Beck, Weisman, Lester, and Trexler, 1976; Bedrosian and Beck, 1979). (F15c) MMPI Second Edition (MMPI-2) and / or the Adolescent Edition (MMPI-A) is an evaluation of mental health, personality and deceptive self-presentation. Across the three editions, with item duplication, the computerized test takes less than 60 minutes to complete. The MMPI-2 for adults has 567 true-false format questions, while the MMPI-A for adolescents has 478 true-false items. Administration via machine-learning on the internet, allows for instantaneous scoring and report generation, with a precision that exceeds $90 \%$, in detecting mental illness. The MMPI alone is not sufficient in assessing violent-prone persons, because within the more than 100 scales, there is no reliable, sensitive-specific, valid measure of violence. This is why, many court, hospital and human resource professionals add a probation parole decision making risk test, like the Standard Predictor to the MMPI. Over 19,000 empirical studies and 250 appellate court cases attest to the usefulness of this assessment, which originated in the 1930s. The QT, MMPI, SP and the other tests in this study,
} 
assess employees in airlines, military, nonprofits/religious organizations, power generation industries, police and fire public safety, trucking and ports, veterans, worker compensation and personal injury insurance clients, and also prisoners (Butcher and Pancheri, 1976; Butcher, Dahlstrom, Graham, Tellegen, and Kaemmer, 1989; Butcher, 1996; Pope, Butcher, and Seelen, 2004; Butcher, Gucher, and Hellervik, 2009). The MMPI-RF was not included. (F15d) Raven Advanced Progressive Matrices ('Raven test': Raven, 1965, 1990) is a norm-referenced measure of visual, nonverbal problem solving, which has been standardized in more than 54 countries (Flynn, 1984, 1987). The 48 challenging problems are presented in a multiple-choice format of 6 or 8 . The computer administration and scoring takes 25 to 45 minutes, depending upon the problem or puzzle capability of the test subject (Shultz, Kaye, and Hoyers, 1980; Dillon, Pohlman, and Lohmen, 1981; Pietariu, 1986). (F15e) Standard Predictor of Violence Potential (SP) is an assessment of adults, with 96 true-false or multiple-choice format items and an Area under the Curve $(A U C)=.99$. The SP for Adolescents has 116 items with $A U C=.91$. The test-retest reliability was $.75-.76$ and Cronbach's alpha of $.75-.78$ with sensitivity of $97 \%$ and specificity of $97 \%$. The SP includes specific, historical self- descriptions and requires 15 minutes to complete. The SP has no items from any of the other tests and is a free standing instrument with 96 or 116 independent items, distinct from the other tests. This measure was successful in discriminating randomly selected violent offenders (1,595 adults and 1,127 adolescents) from matched controls with $A U C=.96$ in a combined adult and adolescent version, based on a sample of 2,722 (Zagar and Grove, 2010). This AUC is noteworthy because most tests in the literature attempting to predict criminal recidivism or "return to court" have AUCs from .7 to .8 (Moosman, 2013). (F16) Data Collection Testing of these individuals was done to assess current functioning and address the hypotheses, as well as the more immediate issues of offering interventions, assessing fitness for duty, schooling, screening, and/ or medical or psychological treatment. Then, records for these individuals were obtained from court, industry, hospital, school, and/or universities. The records were checked and accepted as accurate, with regard to convictions and illnesses. Records were examined for previous court contacts for neglect, substance-dependency, physical and sexual abuse, delinquent and criminal oneness such as truancy, disorderly conduct, solicitation, phone harassment, forgery, mob action, violating a court order, drug possession or sales, property damage, auto theft, theft, burglary, robbery, unlawful weapon possession [firearm(s)], arson, assault or battery, aggravated criminal sexual assault, and homicide (same procedure as used in Zagar, Busch, Grove, and Hughes, 2009, and Zagar, Kovach, Basile, Hughes, Grove, et al., 2013). Of the 146 participants, approximately 20 traveled in for the examinations from adjoining states of Indiana, Michigan, Minnesota, Wisconsin, and New Jersey, referred from airlines, courts, energy production industries, insurance firms, trucking companies, and lawyers. This sample included some people most at-risk for violence, including those with issues related to alcoholism, assault, autism, behavior and emotional school disturbance, career delinquency or criminality, cognitive delay, credibility issues such as malingering and facetiousness, divorce or separation, domestic violence, hyperactivity, lack of work skills, learning disability, physical, sex-offending or homicidal tendencies, marital challenges, mental illness, pedophilia, post-chemotherapy, sexual or verbal abuse, school dropout, somatoform disorders, substance addiction, suicidal attempt or ideation, underachievement, and vocational guidance. The referrals were for competence to stand trial, developmental disability, hearing, motor, speech, or visual challenges, employment hiring, promotion or termination, high school, college, graduate school or seminary entrance, local, national or international adoption, parole or probation hearings, physical or personal injury, pre-sentencing, pre-trail, seminary, travel with pet on airlines, and workers compensation issues. Of course records are not infallible and some individuals with mental illness may go undetected, or not have hospital or legal records. (F17) Psychological Examinations According to the published test manual instructions, two different psychologists administered the QT, the BSS, the MMPI-2/A, Raven and the SP Adult or Adolescent Version The order of test administration was randomized. For the hand scoring of the raw test data, the two independent psychologists had inter-observer agreement (Pearson $r$ s = .93-.94). All of the MMPI data were scored using the Pearson Assessment and University of Minnesota Press computerized Clinical Interpretative Report. The instruments had high test-retest reliability, large standardizations samples, good internal consistency, and high concurrent and construct validity. When possible the tests were administered on the internet. (F18) Records After physical and psychological examinations, current medical and other records were coded using the International Classification of Diseases (ICD-9; World Health Organization, 1977) and the Diagnostic Statistical Manual V (American Psychiatric Association. 2013) and juvenile and adult court and school and industry records were reviewed by two independent psychologists, with coefficients of inter observer agreement of $r=.92-.94$. (F19) The Decision-making Algorithm For adults or adolescents, using the record and test data, two independent psychologists' classified individuals with the following algorithm, to assess mental health including substance-abuse using test results: (a) s QT score below 70 is consistent with cognitively delayed functioning, as was (b) Raven's with a score below 70. (c) A (BSS score of 10-20 or more, in the moderate to severe range of major depression, with suicide ideation. (d) The MMPI-2 (MMPI-2) or the MMPI-A with significantly ( $p<.01)$ elevated validity and/or basic clinical scales consistent with a $t$ score of 65 or above. Finally, (e) the SP Adult version cut-off was $70.6 \%$, the lowest score of convicted violent offenders; the SP Adolescent version cut-off was $82.9 \%$, the lowest score of convicted adolescent violent offenders (Zagar and Grove, 2010). With this decision-making algorithm, for the two independent psychologists, Pearson product moment coefficients of inter-observer agreement were $.92-.96$ ( $p$ $<.01)$. The results of this algorithm were compared with records of the individuals' actual histories. (F20) Statistics and Experimental Design For adults, adolescents, and the combined group (adults plus adolescents), the means and standard deviations were computed for age, sex, race, SES, years of education completed, occupation, and offenses. For adults, adolescents, and the combined group, the test scale means and standard deviations were normally distributed according to the Komolgorov-Smirnov Test and met the assumptions of homogeneity of variance on Bartlett's test. In simple terms, the data was normally distributed and homogenous, conditions for both $t$-tests and analysis of variance (ANOVAs). For the domains and tests employed, the sample size was sufficient (Kirk, 1982). The criterion for mental health including substance-abuse, abuse, and delinquency or crime was the individuals' actual records. These included court or health records of mental illness, substance-abuse, violence, and / or abuse. For example, if the records showed a finding of mental illness, it was assumed that the individual had mental illness, and so forth for the various criteria, substance-abuse, violence, and/or abuse. This carefully selected set of tests was administered either by paper- and-pencil or over the internet with a 


\subsection{Results}

\subsection{Analysis of Variance (ANOVA)}

Since theoretical considerations drove the comparisons, over modeling (Type 1 error) was avoided. The distribution of means and standard deviation t-scores of tests or risks for each subgroup, are shown in Table 3a and 3b. The five study groups' subgroups, whether adult or teen, had unequal sizes, so for clarity, means and standard deviations $t$-scores were presented to allow comparison across tests and subtests, which had also different numbers of items. The adult and teen study groups had significant $(p<.05)$ differences when at-risk were compared with controls. Also, adult and teen subgroups of homicidal, overdosing-substance-abusing, sex-offending, suicide-completers, and controls had similar $t$-score means and standard deviations in the same consistent, replicated pattern of risks, the "7-point violence profile" was expected. See Table 3a, 3b, 3c, and Figures 4 and 5.

\subsection{Adult Homicidal vs. Control Study Groups}

The distributions of means and standard deviations $t$-scores for adult homicidal and control study groups are shown in Table 3a and Figure 4. Significantly $(p<.05)$, adult homicidal compared with controls had higher SP scores, increased MMPI-2 false inconsistency (VRIN), infrequency (F), infrequency at the back end of the test $\left(\mathrm{F}_{\mathrm{B}}\right)$, infrequency of psychopathology $\left(\mathrm{F}_{\mathrm{P}}\right)$, lie $(\mathrm{L})$, defensiveness $(\mathrm{K})$, superlative self-presentation $(\mathrm{S})$, hypochondriasis $(\mathrm{Hs})$, depression (D) (2), psychopathic deviate (Pd) (4), masculinity-femininity (Mf), paranoia (Pa) (6), psychasthenia or obsessive compulsiveness (Pt) (7), schizophrenia (Sc) (8), hypomania or bipolar (Ma) (9), schizophrenia Si (10), alcoholism (MAC-R), and addiction admission (AAS) scores, increased BSS scores, and lower QT receptive vocabulary IQs.

\subsection{Adult Overdosing-Substance-Abusing vs. Control Study Groups}

Significantly $(p<.05)$, adult overdosing-substance-abusing compared with control study groups had higher false inconsistency (VRIN), infrequency $(\mathrm{F})$, infrequency at the back end of the test $\left(\mathrm{F}_{\mathrm{B})}\right.$, infrequency of psychopathology $\left(\mathrm{F}_{\mathrm{P})}\right.$, lie $(\mathrm{L})$, defensiveness $(\mathrm{K})$, superlative self-presentation (S), hypochondriasis (Hs), depression (D) (2), psychopathic deviate (Pd) (4), masculinity-femininity (Mf), paranoia (Pa) (6), psychasthenia or obsessive compulsiveness (Pt) (7), schizophrenia (Sc) (8), hypomania or bipolar (Ma) (9), Si (10), alcoholism (MAC-R), addiction potential (APS), and addiction admission (AAS) MMPI-2 scores, elevated SP scores, increased BSS scores, and lower QT receptive vocabulary IQs as seen in Table 3a and Figure 4.

\subsection{Adult Sex-Offending vs. Control Study Groups}

The distributions of means and standard deviations $t$-scores for adult sex-offending and control study groups are shown in Table 3a and Figure 4. Significantly $(p<.05)$, adult sex-offending compared with controls had higher SP scores, increased false inconsistency (VRIN), infrequency (F), infrequency at the back end of the test $\left(\mathrm{F}_{\mathrm{B}}\right.$, infrequency of psychopathology $\left(\mathrm{F}_{\mathrm{P}}\right.$, lie $(\mathrm{L})$, defensiveness $(\mathrm{K})$, superlative self-presentation $(\mathrm{S})$, hypochondriasis $(\mathrm{Hs})$, depression (D) (2), psychopathic deviate (Pd) (4), masculinity-femininity (Mf), paranoia (Pa) (6), psychasthenia or obsessive compulsiveness (Pt) (7), schizophrenia (Sc) (8), hypomania or bipolar (Ma) (9), and social introversion (Si) (10), alcoholism (MAC-R), and addiction admission (AAS) MMPI-2 scores, increased BSS scores, but lower QT receptive vocabulary IQs.

\subsection{Adult Suicide-Completers vs. Control Study Groups}

The distributions of means and standard deviation $t$-scores of adult suicide-completers and control study groups are shown in Table 3a and Figure 4. Significantly $(p<.05)$, adult suicide-completers compared with controls had higher SP, increased false inconsistency (VRIN), infrequency $(\mathrm{F})$, infrequency at the back end of the test $\left(\mathrm{F}_{\mathrm{B})}\right.$, infrequency of psychopathology $\left(\mathrm{F}_{\mathrm{P})}\right.$, lie $(\mathrm{L})$, defensiveness $(\mathrm{K})$, superlative self-presentation $(\mathrm{S})$, hypochondriasis $(\mathrm{Hs})$, depression $(\mathrm{D})$ (2), psychopathic deviate (Pd) (4), masculinity-femininity (Mf), paranoia (Pa) (6), psychasthenia or obsessive compulsiveness (Pt) (7), schizophrenia ( $\mathrm{Sc}$ ) (8), hypomania or bipolar (Ma) (9), and social introversion (Si) (10), alcoholism (MAC-R), and addiction admission (AAS) MMPI-2, increased BSS, but lower QT vocabulary IQs.

total test time of $110-440 \mathrm{~min}$. for 823 items. In the internet format, tests with automated reports cost 70 to $80 \%$ less than current paper-and-pencil version reports. Also, percentiles, raw and $t$ scores, and cut-offs were available instantaneously, except for MMPI clinical interpretative report, which does not provide percentiles but t-scores. When the paper-and-pencil versions were used, two independent psychologists verified the entry independently, matching the computerized reports with $r=.98$ consistency, because most jails and prisons and some other situations, do not allow computers. First, the adult 5 group data were subjected one way ANOVA. Then the teen data were subject to ANOVA. All of the psychometric measures or dependent measures met the assumptions of normality (Kolmogorov Smirnov Tests) and homogeneity of variance (Bartlett's Tests). 
Table 3a. Adult $(N=79)$ Homicidal, Overdosing, Sex-Offending, Suicide-Completers, and Controls Average and Standard Deviation $t$-scores and ANOVA Fs with "7-Point Violence Profile"

\begin{tabular}{|c|c|c|c|c|c|c|}
\hline $\begin{array}{l}\text { Test(subtest) } \\
t \text { - scores } \\
(M=50, S D=10)\end{array}$ & $\begin{array}{l}\text { Homicidal } \\
(n=12)\end{array}$ & $\begin{array}{l}\text { Overdosing- } \\
\text { Substance-Abusing } \\
(n=13)\end{array}$ & $\begin{array}{l}\text { Sex- } \\
\text { Offending } \\
(n=15)\end{array}$ & $\begin{array}{l}\text { Suicide- } \\
\text { Completers } \\
(n=15)\end{array}$ & $\begin{array}{l}\text { Controls } \\
(n=24)\end{array}$ & $F_{4}$ \\
\hline BSS & $\begin{array}{l}56.75 \\
(14.60)\end{array}$ & $\begin{array}{l}65.38 \\
(17.45)\end{array}$ & $\begin{array}{l}57.80 \\
(14.66)\end{array}$ & $\begin{array}{l}72.87 \\
(9.09)\end{array}$ & $\begin{array}{l}45.58 \\
(3.43)\end{array}$ & $13.73+$ \\
\hline Standard Predictor & $\begin{array}{l}63.25 \\
(12.22)\end{array}$ & $\begin{array}{c}51.08 \\
(0.28) \\
\end{array}$ & $\begin{array}{l}64.2 \\
(10.95)\end{array}$ & $\begin{array}{l}69.47 \\
(14.39) \\
\end{array}$ & $\begin{array}{l}52.37 \\
(3.35)\end{array}$ & $11.79+$ \\
\hline QT Vocabulary IQ & $\begin{array}{l}54.63 \\
(14.13)\end{array}$ & $\begin{array}{l}50.62 \\
(8.87)\end{array}$ & $\begin{array}{l}56.8 \\
(7.91)\end{array}$ & $\begin{array}{l}50.74 \\
(9.24)\end{array}$ & $\begin{array}{l}61.67 \\
(9.21)\end{array}$ & $4.11+$ \\
\hline MMPI-2 VRIN & $\begin{array}{l}58.25 \\
(9.74)\end{array}$ & $\begin{array}{l}61.62 \\
(10.37) \\
\end{array}$ & $\begin{array}{l}62.27 \\
(8.65)\end{array}$ & $\begin{array}{l}61.73 \\
(13.33) \\
\end{array}$ & $\begin{array}{l}44.83 \\
(8.15)\end{array}$ & $11.36+$ \\
\hline MMPI-2 F & $\begin{array}{l}76.83 \\
(10.93) \\
\end{array}$ & $\begin{array}{c}69.54 \\
(11.5) \\
\end{array}$ & $\begin{array}{l}76.73 \\
((9.79)\end{array}$ & $\begin{array}{l}72.6 \\
(11.54)\end{array}$ & $\begin{array}{c}4.88 \\
(6.12)\end{array}$ & $38.74+$ \\
\hline MMPI-2-Fb & $\begin{array}{l}72.83 \\
(16.04) \\
\end{array}$ & $\begin{array}{l}79.31 \\
(18.88) \\
\end{array}$ & $\begin{array}{l}75.3 \\
(15.36) \\
\end{array}$ & $\begin{array}{l}66.4 \\
(16.99) \\
\end{array}$ & $\begin{array}{r}46.96 \\
(4.94) \\
\end{array}$ & $15.96+$ \\
\hline MMPI-2 Fp & $\begin{array}{l}68.25 \\
(13.08)\end{array}$ & $\begin{array}{l}74.77 \\
(15.31)\end{array}$ & $\begin{array}{l}68.80 \\
(12.65)\end{array}$ & $\begin{array}{l}66.20 \\
(10.65)\end{array}$ & $\begin{array}{r}44.17 \\
(5.37)\end{array}$ & $22.51+$ \\
\hline MMPI-2 L & $\begin{array}{l}59.67 \\
(9.43)\end{array}$ & $\begin{array}{l}53.85 \\
(11.24)\end{array}$ & $\begin{array}{l}57.80 \\
(11.54)\end{array}$ & $\begin{array}{l}63.47 \\
(12.19)\end{array}$ & $\begin{array}{l}52.46 \\
(11.98)\end{array}$ & $2.56^{*}$ \\
\hline MMPI-2 K & $\begin{array}{l}44.75 \\
(8.45)\end{array}$ & $\begin{array}{l}49.77 \\
(12.5)\end{array}$ & $\begin{array}{l}50.33 \\
(12.37)\end{array}$ & $\begin{array}{l}54.13 \\
(9.32)\end{array}$ & $\begin{array}{l}57.75 \\
(11.94)\end{array}$ & $3.16^{*}$ \\
\hline MMPI-2 S & $\begin{array}{l}43.58 \\
(8.96) \\
\end{array}$ & $\begin{array}{l}45.46 \\
(10.71) \\
\end{array}$ & $\begin{array}{l}48.0 \\
(8.79)\end{array}$ & $\begin{array}{l}51.13 \\
(12.41)\end{array}$ & $\begin{array}{l}57.04 \\
(10.94)\end{array}$ & $4.54+$ \\
\hline MMPI-2-1 Hs & $\begin{array}{l}59.33 \\
(14.62) \\
\end{array}$ & $\begin{array}{l}68.77 \\
(9.66) \\
\end{array}$ & $\begin{array}{l}64.93 \\
(11,29) \\
\end{array}$ & $\begin{array}{l}63.47 \\
(10.88) \\
\end{array}$ & $\begin{array}{l}48.04 \\
(9.97) \\
\end{array}$ & $9.94+$ \\
\hline MMPI-2- 2 D & $\begin{array}{l}74.50 \\
(17.50)\end{array}$ & $\begin{array}{l}73.54 \\
(10.81)\end{array}$ & $\begin{array}{c}74.13 \\
(7.08)\end{array}$ & $\begin{array}{c}68.93 \\
(10.9)\end{array}$ & $\begin{array}{l}49.00 \\
(8.69)\end{array}$ & $20.11+$ \\
\hline MMPI-2 4 Pd & $\begin{array}{l}67.42 \\
(7.82) \\
\end{array}$ & $\begin{array}{l}79.00 \\
(9.28) \\
\end{array}$ & $\begin{array}{l}73.0 \\
(12.69) \\
\end{array}$ & $\begin{array}{l}74.33 \\
(10.24) \\
\end{array}$ & $\begin{array}{l}53.83 \\
(11.35) \\
\end{array}$ & $16.22+$ \\
\hline MMPI-2 -5 Mf & $\begin{array}{l}53.58 \\
(7.24) \\
\end{array}$ & $\begin{array}{l}56.0 \\
(13.02) \\
\end{array}$ & $\begin{array}{l}54.27 \\
(6.44) \\
\end{array}$ & $\begin{array}{l}57.27 \\
(6.54) \\
\end{array}$ & $\begin{array}{l}48.17 \\
(10.59) \\
\end{array}$ & $2.84^{*}$ \\
\hline MMPI-2-6 Pa & $\begin{array}{l}73.67 \\
(7.55) \\
\end{array}$ & $\begin{array}{l}81.77 \\
(9.33) \\
\end{array}$ & $\begin{array}{l}81.47 \\
(10.41) \\
\end{array}$ & $\begin{array}{l}78.93 \\
(7.77) \\
\end{array}$ & $\begin{array}{l}51.29 \\
(10.31) \\
\end{array}$ & $38.53+$ \\
\hline MMPI-2 -7 Pt & $\begin{array}{l}63.75 \\
(13.25)\end{array}$ & $\begin{array}{l}71.69 \\
(11.67)\end{array}$ & $\begin{array}{l}69.73 \\
(13.08)\end{array}$ & $\begin{array}{l}66.0 \\
(11.83)\end{array}$ & $\begin{array}{c}49.58 \\
(7.46)\end{array}$ & $12.24+$ \\
\hline MMPI-2-8 Sc & $\begin{array}{l}75.75 \\
(15.55)\end{array}$ & $\begin{array}{l}81.08 \\
(10.33)\end{array}$ & $\begin{array}{l}80.33 \\
(13.2)\end{array}$ & $\begin{array}{l}77.33 \\
(15.14)\end{array}$ & $\begin{array}{l}51.96 \\
(8.45)\end{array}$ & $20.07+$ \\
\hline MMPI-2-9-Ma & $\begin{array}{l}52.42 \\
(11.6) \\
\end{array}$ & $\begin{array}{l}67.31 \\
(8.12) \\
\end{array}$ & $\begin{array}{l}58.67 \\
(11.82)\end{array}$ & $\begin{array}{l}60.33 \\
(13.81)\end{array}$ & $\begin{array}{l}48.71 \\
(9.69)\end{array}$ & $7.08+$ \\
\hline MMPI-2- $10 \mathrm{Si}$ & $\begin{array}{l}60.17 \\
(9.13) \\
\end{array}$ & $\begin{array}{l}58.0 \\
(8.09) \\
\end{array}$ & $\begin{array}{l}59.2 \\
(8.22) \\
\end{array}$ & $\begin{array}{l}52.73 \\
(7.94) \\
\end{array}$ & $\begin{array}{l}46.38 \\
(8.67) \\
\end{array}$ & $8.75+$ \\
\hline MMPI-2 MAC-R & $\begin{array}{l}53.00 \\
(11.05) \\
\end{array}$ & $\begin{array}{l}59.69 \\
(12.88)\end{array}$ & $\begin{array}{l}57.47 \\
(4.45)\end{array}$ & $\begin{array}{c}55.73 \\
(7.96) \\
\end{array}$ & $\begin{array}{l}48.46 \\
(8.64)\end{array}$ & $4.15+$ \\
\hline MMPI-2 AAS & $\begin{array}{l}50.50 \\
(7.73)\end{array}$ & $\begin{array}{l}66.00 \\
(11.22)\end{array}$ & $\begin{array}{l}61.53 \\
(15.95)\end{array}$ & $\begin{array}{l}52.40 \\
(9.96)\end{array}$ & $\begin{array}{l}46.83 \\
(8.47)\end{array}$ & $8.71+$ \\
\hline
\end{tabular}

Note.-The MMPI-2 and MMPI-A have different items, sets, and length, i.e. 567 vs. 468 items with the same 13 basic clinical and 3 validity scales; scores cannot be added; $+p<.01 * p<.05$. 


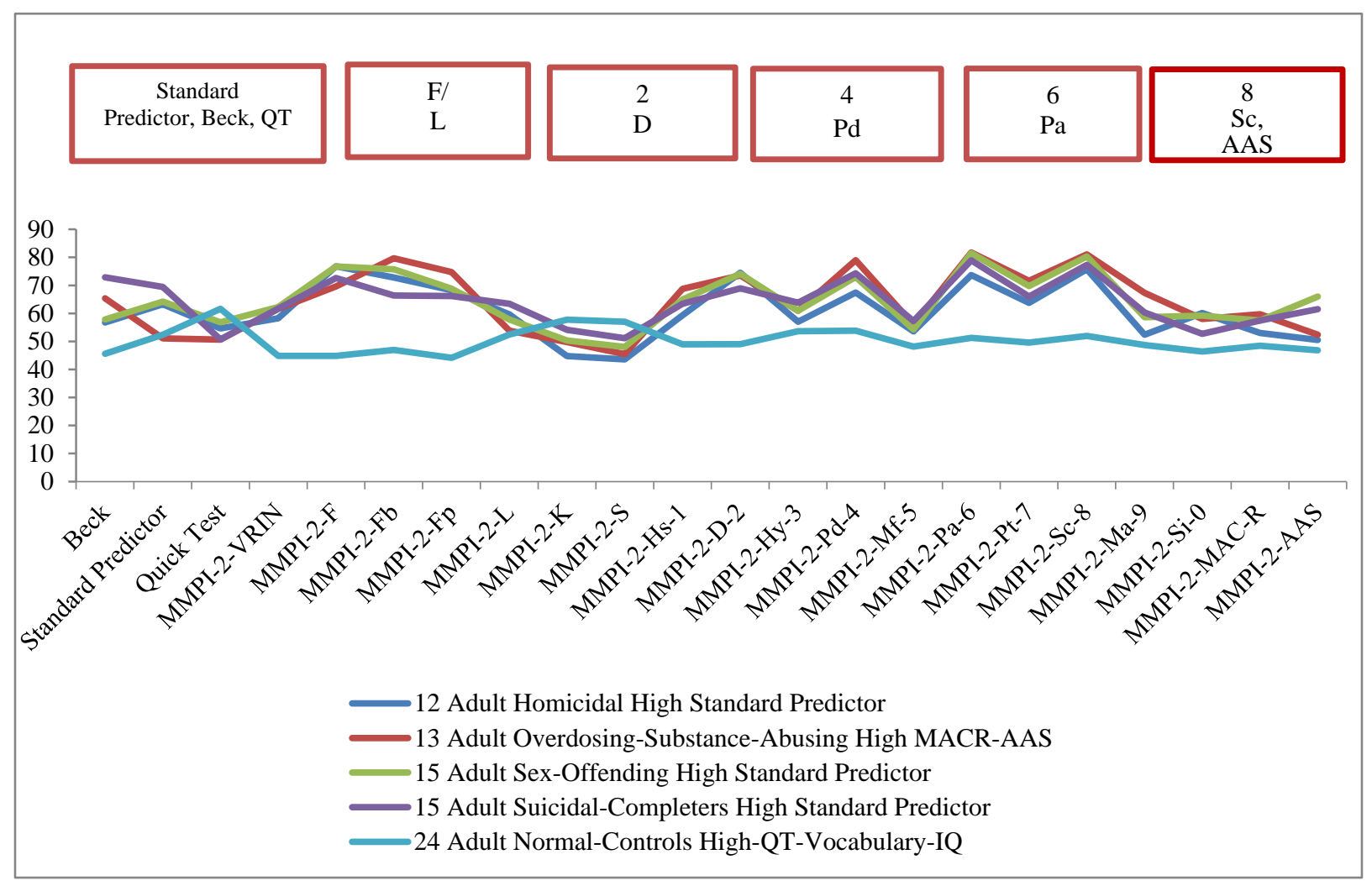

Figure 4. "Adult (N=79) 7-Point Violence Profile:" Mean $t$-Scores of BSS, SP, QT, and MMPI-2 Faking/Lying (F/L) Depression (D) Psychopathic Deviate (Pd) Paranoia (Pa) Schizophrenia (Sc) and Addiction Admission (AAS) Subtests

In viewing Figure 4 , the adult average and standard deviation $t$-scores of the BSS, MMPI-2, QT, and SP, were significantly $(p<.05$.) higher for the four at-risk study groups (homicidal, overdosing-substance-abusing, sex-offending, suicide-completers) compared with control study group. This is consistent with what was found among the teens and confirms similar profiles from 320,051 subjects in 212 studies over 95 years. The suicidal-overdosing followed by the sex-offending, and the homicidal study groups had t-scores at least one standard deviation above normal $\left(t_{\text {mean }}=50\right.$; $t_{\text {standard deviation }}=10$ ). The small sample sizes may account for homicidal study group having lower violence potential scores than the other at-risk study groups.

\subsection{Teen Homicidal vs. Control Study Groups}

The distributions of means and standard deviation $t$-scores of teen homicidal and control study groups are shown in Table $3 \mathrm{~b}$ and Figure 5. Significantly $(p<.05)$, teen homicidal compared with control study groups had higher SP scores, increased exaggeration (F1), lie (L), defensiveness (K), depression (D) (2), psychopathic deviate (Pd) (4), paranoia (Pa) (6), schizophrenia (Sc) (8), and addiction admission (ACK) MMPI-A scores, and elevated BSS scores, but lower Raven problem solving IQs.

\subsection{Teen Overdosing-Substance-Abusing vs. Control Study Groups}

The distributions of means and standard deviation $t$-scores of teen overdosing-substance-abusing and control study groups are shown in Table $3 \mathrm{~b}$ and Figure 5. Significantly $(p<.05)$, teen overdosing-substance-abusing compared with controls, had increased SP scores, higher exaggeration (F1), lie (L), defensiveness (K), depression (D) (2), psychopathic deviate (Pd) (4), paranoia (Pa) (6), schizophrenia (Sc) (8), and addiction acknowledgement (ACK) MMPI-A scores, and elevated BSS scores, but lower Raven problem solving IQs.

\subsection{Teen Sex-Offending vs. Control Study Groups}

The distributions of means and standard deviations of $t$-scores of teen suicide-completer and control study groups are shown in Table $3 \mathrm{~b}$ and Figure 5. Significantly ( $p<.05)$, teen suicide-completers compared with controls had higher SP scores, increased exaggeration (F1), lie (L), defensiveness (K), depression (D) (2), psychopathic deviate (Pd) (4), paranoia (Pa) (6), schizophrenia (Sc) (8), and addiction acknowledgement (ACK) MMPI-A scores, and increased BSS scores, but lower Raven problem solving IQs. 


\subsection{Teen Suicide-Completers vs. Control Study Groups}

In Table $3 \mathrm{~b}$ and Figure 5, the distributions of means and standard deviations $t$-scores of teen suicide-completer and control study groups are shown. Significantly $(p<.05)$, the teen suicide-completers compared with control study group had higher SP scores, increased exaggeration (F1), lie (L), defensiveness (K), depression (D) (2), psychopathic deviate (Pd) (4), paranoia (Pa) (6), schizophrenia ( $\mathrm{Sc}$ ) 8), addiction acknowledgement (ACK) MMPI-A scores, and elevated BSS scores, but lower Raven problem solving IQs.

Table 3b. Teen $(N=57)$ Homicidal, Overdosing, Sex-Offending, Suicide-Completers \& Controls Average and Standard Deviation $t$-scores and ANOVA Fs with "7-Point Violence Profile"

\begin{tabular}{|c|c|c|c|c|c|c|}
\hline $\begin{array}{l}\text { Test (subtest) } t \text {-scores } \\
(M=50, S D=10)\end{array}$ & $\begin{array}{l}\text { Homicidal } \\
\text { Teens } \\
(n=11)\end{array}$ & $\begin{array}{l}\text { Overdosing } \\
\text { Teens } \\
(n=7)\end{array}$ & $\begin{array}{l}\text { Sex-Offending } \\
\text { Teens } \\
(n=10)\end{array}$ & $\begin{array}{l}\text { Suicide-Completer } \\
\text { Teens } \\
(n=17)\end{array}$ & $\begin{array}{l}\text { Control } \\
\text { Teens } \\
(n=12)\end{array}$ & $F_{4}$ \\
\hline BSS & $\begin{array}{l}46.36 \\
(3.32) \\
\end{array}$ & $\begin{array}{l}62.71 \\
(21.96) \\
\end{array}$ & $\begin{array}{l}58.50 \\
(21.24) \\
\end{array}$ & $\begin{array}{l}83.12 \\
(12.78) \\
\end{array}$ & $\begin{array}{l}44.08 \\
(2.23) \\
\end{array}$ & $18.93+$ \\
\hline Standard Predictor & $\begin{array}{l}81.36 \\
(7.62)\end{array}$ & $\begin{array}{l}55.86 \\
(12.43) \\
\end{array}$ & $\begin{array}{l}74.8 \\
(18.41)\end{array}$ & $\begin{array}{l}52.33 \\
(9.99)\end{array}$ & $\begin{array}{l}51.25 \\
(3.45)\end{array}$ & $23.72+$ \\
\hline Raven & $\begin{array}{l}43.55 \\
(7.30)\end{array}$ & $\begin{array}{l}50.43 \\
(2.15)\end{array}$ & $\begin{array}{l}46.0 \\
(9.43)\end{array}$ & $\begin{array}{l}46.71 \\
(11.46)\end{array}$ & $\begin{array}{l}54.67 \\
(8.76)\end{array}$ & $2.59 *$ \\
\hline MMPI-A-F1 & $\begin{array}{l}53.64 \\
(5.89)\end{array}$ & $\begin{array}{l}57.00 \\
(10.77)\end{array}$ & $\begin{array}{l}62.3 \\
(6.45) \\
\end{array}$ & $\begin{array}{l}62.06 \\
(7.17)\end{array}$ & $\begin{array}{l}53.08 \\
(8.07)\end{array}$ & $3.41+$ \\
\hline MMPI-A -L & $\begin{array}{r}54.55 \\
(8.71) \\
\end{array}$ & $\begin{array}{l}57.43 \\
(13.39) \\
\end{array}$ & $\begin{array}{l}67.6 \\
(11.64)\end{array}$ & $\begin{array}{l}56.29 \\
(13.56) \\
\end{array}$ & $\begin{array}{l}49.17 \\
(9.31) \\
\end{array}$ & $3.60+$ \\
\hline MMPI-A-K & $\begin{array}{l}50.00 \\
(6.63)\end{array}$ & $\begin{array}{l}59.00 \\
(6.62)\end{array}$ & $\begin{array}{l}46.3 \\
(7.21)\end{array}$ & $\begin{array}{l}54.82 \\
(12.12)\end{array}$ & $\begin{array}{l}44.50 \\
(7.26)\end{array}$ & $4.35+$ \\
\hline MMPI-A-2 & $\begin{array}{l}70.36 \\
(11.72)\end{array}$ & $\begin{array}{l}63.43 \\
(11.24)\end{array}$ & $\begin{array}{l}76.6 \\
(10.69)\end{array}$ & $\begin{array}{l}71.23 \\
(11.22)\end{array}$ & $\begin{array}{l}55.17 \\
(9.21)\end{array}$ & $6.59+$ \\
\hline MMPI-A -4-Pd & $\begin{array}{l}74.18 \\
(12.55) \\
\end{array}$ & $\begin{array}{l}66.57 \\
(9.32) \\
\end{array}$ & $\begin{array}{l}78.2 \\
(14.37) \\
\end{array}$ & $\begin{array}{l}67.82 \\
(8.88) \\
\end{array}$ & $\begin{array}{l}51.58 \\
(4.70) \\
\end{array}$ & $11.15+$ \\
\hline MMPI-A -6 Pa & $\begin{array}{l}81.91 \\
(18.45) \\
\end{array}$ & $\begin{array}{l}70.0 \\
(8.83) \\
\end{array}$ & $\begin{array}{l}74.4 \\
(13.99) \\
\end{array}$ & $\begin{array}{l}63.35 \\
(16.18) \\
\end{array}$ & $\begin{array}{l}54.42 \\
(6.04) \\
\end{array}$ & $6.54+$ \\
\hline MMPI-A -8-Sc & $\begin{array}{l}71.82 \\
(14.63) \\
\end{array}$ & $\begin{array}{l}66.14 \\
(6.26) \\
\end{array}$ & $\begin{array}{l}67.7 \\
(7.78) \\
\end{array}$ & $\begin{array}{l}64.53 \\
(13.78) \\
\end{array}$ & $\begin{array}{l}55.33 \\
(6.61) \\
\end{array}$ & $3.46+$ \\
\hline MMPI-A -ACK & $\begin{array}{l}59.82 \\
(7.48)\end{array}$ & $\begin{array}{l}64.57 \\
(15.18)\end{array}$ & $\begin{array}{l}59.60 \\
(9.52)\end{array}$ & $\begin{array}{l}55.53 \\
(5.94)\end{array}$ & $\begin{array}{l}52.67 \\
(8.13)\end{array}$ & $2.57^{*}$ \\
\hline
\end{tabular}

Note.-The MMPI-2 and MMPI-A have different items, sets, and length, i.e. 567 vs. 468 items with the same 13 basic clinical and 3 validity scales; scores cannot be added; $+p<.01 * p<.05$.

In viewing Figure 5 , it is clearly seen that the teen average and standard deviation $t$-scores of the BSS, MMPI-A, QT, and SP, were significantly ( $p<.05$.) higher for the four at-risk study groups (homicidal, overdosing-substance-abusing, sex-offending, suicide-completers) compared with controls. This is consistent with what was found among the adult study groups and is consonant similar profiles from 320,051 subjects in 212 studies over 95 years. In this comparison of teen study groups, the homicidal study group, followed by the sex-offending study group, had the highest violence potential scores.

\subsection{Comparing Adult and Teen Study Groups Average t-Scores}

When the adult $(N=79)$ and teen $(N=57)$ homicidal, overdosing, sex-offending, suicide-completer, and control study groups average and standard deviation $t$-scores of the SP, BSS, and MMPI-2/A were compared, they were similar. The ANOVA Fs were insignificant $(p<.05)$. This means that the adult and teen study groups of homicidal, overdosing, sex-offending, suicide-completers, and controls were homogenous. This also can be interpreted as the BSS MMPI-2/A, QT, Raven, and SP were consistent in measuring the constructs across homogenous at-risk groups, whether adult or 
teen.

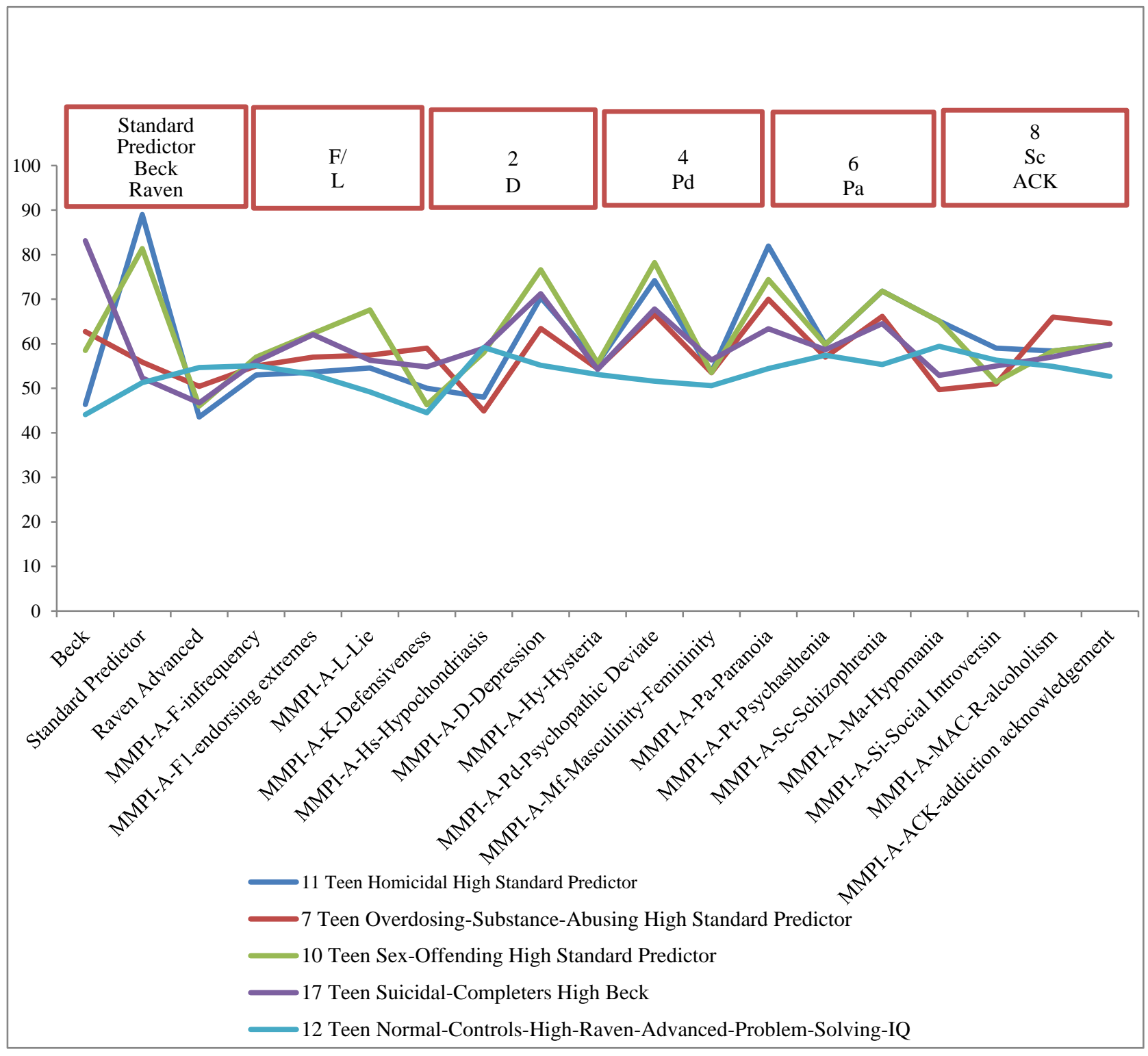

Figure 5. Teen (N=57)"7-Point Violence Profile": BSS, SP, Raven, and MMPI-A Faking/Lying (F/L) Depression (D) Psychopathic Deviate (Pd) Paranoia (Pa) Schizophrenia (Sc) Addiction Acknowledgement (ACK)

See Table 3c. In Table 3d there is a summary of the "7-point violence profile" across adult and teen homicidal, overdosing, sex-offending and suicidal-completers, namely the BSS, SP, Raven, and MMPI-2/A faking, depression, psychopathic deviate, paranoia and schizophrenia scales or "F-2-4-6-8."

\subsection{Internal, External, Construct, and Statistical Conclusion Validity Threats}

Variations in means, standard deviations and ANOVA Fs are due to error in tests or testing, differences in the history of individuals within subgroups, generalizability, measured traits, measurement, reliability, sampling variations, selection error, setting of the test administration, time of original data collection, scaling, statistical analyses, validity and probably many unknown factors. Despite this variability and the overlap of ranges, when at-risk male and female, adult and teen, homicidal, overdosing-substance-abusing, sex-offending, suicide-completer study groups were compared with control study groups, the data were robust enough to identify significant differences. Researchers in the past century have found overlap and variability in assessing at-risk. Such variability is the reason why, careful attention to detail and longitudinal data collection from multiple examinations in many settings is necessary in this kind of study. For over a century, the Circuit Court of Cook County has collected multiple examinations and records 
from many sources. The risks found among high-density urban, adult and teen, homicidal, overdosing, sex-offending, and suicide-completers were similar to the findings in abovementioned research findings around the world.

Table 3c. Similar Adult \& Teen "7-Point Violence Profile" for Homicidal, Overdosing, Sex-Offending, Suicidal, \& Controls Average and Standard Deviation Scores and ANOVA Fs

\begin{tabular}{|c|c|c|c|c|c|c|c|c|c|c|c|c|c|c|c|}
\hline $\begin{array}{l}\text { Test } \\
t \text {-scores } \\
(M=50, \\
S D=10)\end{array}$ & $\begin{array}{l}12 \\
\text { Homi- } \\
\text { cidal } \\
\text { Adults }\end{array}$ & $\begin{array}{l}11 \\
\text { Homi- } \\
\text { cidal } \\
\text { Teens }\end{array}$ & $\mathrm{F}_{22}$ & $\begin{array}{l}13 \\
\text { Over- } \\
\text { dosing } \\
\text { Adults }\end{array}$ & $\begin{array}{l}7 \\
\text { Over- } \\
\text { dosing } \\
\text { Teens }\end{array}$ & $\mathrm{F}_{19}$ & $\begin{array}{l}15 \\
\text { Sex-Of- } \\
\text { fending } \\
\text { A- dults }\end{array}$ & $\begin{array}{l}10 \\
\text { Sex-Of- } \\
\text { fending } \\
\text { Teens }\end{array}$ & $\mathrm{F}_{24}$ & $\begin{array}{l}15 \\
\text { Suicide- } \\
\text { Completer } \\
\text { Adults }\end{array}$ & $\begin{array}{l}17 \\
\text { Suicide- } \\
\text { Completer } \\
\text { Teens }\end{array}$ & $\mathrm{F}_{31}$ & $\begin{array}{l}24 \\
\text { Control } \\
\text { Adults }\end{array}$ & $\begin{array}{l}12 \\
\text { Control } \\
\text { Teens }\end{array}$ & $\mathrm{F}_{35}$ \\
\hline BSS & $\begin{array}{l}56.75 \\
14.60 \\
\end{array}$ & $\begin{array}{l}46.36 \\
3.32 \\
\end{array}$ & $4.67 *$ & $\begin{array}{l}65.38 \\
17.45 \\
\end{array}$ & $\begin{array}{l}62.71 \\
21.96 \\
\end{array}$ & 0.09 & $\begin{array}{l}57.80 \\
14.66 \\
\end{array}$ & $\begin{array}{l}58.50 \\
21.24 \\
\end{array}$ & 0.01 & $\begin{array}{l}72.87 \\
9.09\end{array}$ & $\begin{array}{l}83.12 \\
12.78 \\
\end{array}$ & $6.66^{*}$ & $\begin{array}{l}45.58 \\
3.43 \\
\end{array}$ & $\begin{array}{l}44.08 \\
2.23 \\
\end{array}$ & 1.88 \\
\hline SP & $\begin{array}{l}63.25 \\
12.22 \\
\end{array}$ & $\begin{array}{l}81.36 \\
7.62 \\
\end{array}$ & $11.33+$ & $\begin{array}{l}51.08 \\
0.28 \\
\end{array}$ & $\begin{array}{l}55.86 \\
12.43 \\
\end{array}$ & 2.02 & $\begin{array}{l}64.2 \\
10.95 \\
\end{array}$ & $\begin{array}{l}74.8 \\
18.41 \\
\end{array}$ & 3.28 & $\begin{array}{l}69.47 \\
14.39 \\
\end{array}$ & 52.339 .99 & 2.45 & $\begin{array}{l}52.37 \\
3.35 \\
\end{array}$ & $\begin{array}{l}51.25 \\
3.45 \\
\end{array}$ & 1.48 \\
\hline $\begin{array}{l}\text { MMPI-2/A } \\
\text { L }\end{array}$ & $\begin{array}{l}59.67 \\
9.43 \\
\end{array}$ & $\begin{array}{l}54.55 \\
8.71 \\
\end{array}$ & 0.84 & $\begin{array}{l}53.85 \\
11.24 \\
\end{array}$ & $\begin{array}{l}50.43 \\
2.15 \\
\end{array}$ & 0.41 & $\begin{array}{l}57.80 \\
11.54 \\
\end{array}$ & $\begin{array}{l}67.6 \\
11.64 \\
\end{array}$ & $4.30^{*}$ & $\begin{array}{l}63.47 \\
12.19 \\
\end{array}$ & $\begin{array}{l}56.29 \\
13.56 \\
\end{array}$ & 0.03 & $\begin{array}{l}52.46 \\
11.98 \\
\end{array}$ & $\begin{array}{l}49.17 \\
9.31 \\
\end{array}$ & 0.69 \\
\hline $\begin{array}{l}\text { MMPI-2/A } \\
\mathrm{K}\end{array}$ & $\begin{array}{l}44.75 \\
8.45 \\
\end{array}$ & $\begin{array}{l}50.00 \\
6.63 \\
\end{array}$ & 3.95 & $\begin{array}{l}49.77 \\
12.5 \\
\end{array}$ & $\begin{array}{l}57.00 \\
10.77 \\
\end{array}$ & 3.01 & $\begin{array}{l}50.33 \\
12.37 \\
\end{array}$ & $\begin{array}{r}46.3 \\
7.21 \\
\end{array}$ & 0.86 & $\begin{array}{l}54.13 \\
9.32 \\
\end{array}$ & $\begin{array}{l}54.82 \\
12.12 \\
\end{array}$ & 0.34 & $\begin{array}{l}57.75 \\
11.94 \\
\end{array}$ & $\begin{array}{l}44.50 \\
7.26 \\
\end{array}$ & $12.39+$ \\
\hline $\begin{array}{l}\text { MMPI 2/A } \\
\text { D } 2\end{array}$ & $\begin{array}{l}74.50 \\
17.50\end{array}$ & $\begin{array}{l}70.36 \\
11.72\end{array}$ & 0.34 & $\begin{array}{l}73.54 \\
10.81\end{array}$ & $\begin{array}{l}57.43 \\
13.39\end{array}$ & 3.88 & $\begin{array}{l}74.13 \\
7.08\end{array}$ & $\begin{array}{l}76.6 \\
10.69\end{array}$ & 0.48 & $\begin{array}{r}68.93 \\
10.9\end{array}$ & $\begin{array}{l}71.23 \\
11.22\end{array}$ & 0.56 & $\begin{array}{l}49.0 \\
8.69\end{array}$ & $\begin{array}{l}55.17 \\
9.21\end{array}$ & 3.87 \\
\hline $\begin{array}{l}\text { MMPI-2/A } \\
\text { Pd } 4\end{array}$ & $\begin{array}{l}67.42 \\
7.82\end{array}$ & $\begin{array}{l}74.18 \\
12.55\end{array}$ & 0.93 & $\begin{array}{l}79.00 \\
9,28\end{array}$ & $\begin{array}{l}59.00 \\
6.62\end{array}$ & $8.13^{*}$ & $\begin{array}{l}73.0 \\
12.69\end{array}$ & $\begin{array}{l}78.2 \\
14.37\end{array}$ & 0.91 & $\begin{array}{l}74.33 \\
10.24\end{array}$ & 67.828 .88 & 3.71 & $\begin{array}{l}53.83 \\
11.35\end{array}$ & $\begin{array}{l}51.58 \\
4.70\end{array}$ & 0.43 \\
\hline $\begin{array}{l}\text { MMPI-2/A } \\
\mathrm{Pa} 6\end{array}$ & $\begin{array}{l}73.67 \\
7.55 \\
\end{array}$ & $\begin{array}{l}81.91 \\
18.45 \\
\end{array}$ & 0,08 & $\begin{array}{l}81.77 \\
(10.33) \\
\end{array}$ & $\begin{array}{l}63.43 \\
(11.24) \\
\end{array}$ & $7.50+$ & $\begin{array}{l}81.47 \\
10.41 \\
\end{array}$ & $\begin{array}{l}74.4 \\
13.99 \\
\end{array}$ & 2.10 & $\begin{array}{l}78.93 \\
7.77 \\
\end{array}$ & $\begin{array}{l}63.35 \\
(16.18) \\
\end{array}$ & $11.53+$ & $\begin{array}{l}51.29 \\
10.31 \\
\end{array}$ & $\begin{array}{l}54.42 \\
6.04 \\
\end{array}$ & 0.93 \\
\hline $\begin{array}{l}\text { MMPI-2/A } \\
\text { Sc } 8\end{array}$ & $\begin{array}{l}75.75 \\
15.55\end{array}$ & $\begin{array}{l}71.82 \\
14.63\end{array}$ & 0.72 & $\begin{array}{l}81.08 \\
10.33\end{array}$ & $\begin{array}{l}66.57 \\
9.32\end{array}$ & $12.05+$ & $\begin{array}{l}80.33 \\
13.2\end{array}$ & $\begin{array}{l}67.7 \\
7.78\end{array}$ & $7.38^{*}$ & $\begin{array}{l}77.33 \\
15.14\end{array}$ & $\begin{array}{l}64.53 \\
13.78\end{array}$ & $6.27 *$ & $\begin{array}{l}51.96 \\
8.45\end{array}$ & $\begin{array}{l}55.33 \\
6.61\end{array}$ & 1.46 \\
\hline
\end{tabular}

Note.-The MMPI- 2 and MMPI-Ahave different items, sets, and length, i.e. 567 vs. 468 items with the same 13 basic clinical and 3 validity scales; scores cannot be added; $+p<.01 * p<.05$.

Table 3d. "7-Point Violence Profile" of SP, BSS and MMPI-2/A Infrequency Depression Psychopathic Deviate Paranoia Schizophrenia or "F-2-4-6-8" Scales.

\begin{tabular}{l|l}
\hline Homicidal Adults \& Teens & SP, BSS, MMPI-2/A"F-L-2-4-6-8-AAS (ACK)" \\
\hline Overdosing-Substance-Abusing Adults and Teens & SP, BSS, MMPI-2/A “F-2-4-6-8-AAS(ACK)" \\
\hline Sex-Offending Adults and Teens & SP, BSS, MMPI-2/A “F-L-2-4-6-8-AAS(ACK)" \\
\hline Suicide-Completer Adults and Teens & SP, BSS, MMPI-2/A “F-L-2-4-6-8-AAS(ACK)" \\
\hline "7-Point Violence Profile" (SP, BSS \& MMPI-2/A) & $\begin{array}{l}\text { SP BSS infrequency/lie (deception), depression, } \\
\text { psychopathic-deviance, paranoia, schizophrenic thinking, } \\
\text { addiction }\end{array}$ \\
\hline
\end{tabular}

\section{Discussion of How Using MLIT Widely Might Save Lives \& Trillions}

Whether among adults or teens, there were significant $(p<.05)$ fluctuations in the deceptive self-presentation, psycho-pathology, suicide ideation, violence potential, receptive vocabulary and problem solving IQ t-scores, when homicidal, overdosing-substance-abusing, sex-offending and suicide-completer study groups were compared with control study groups. These results paralleled 212 studies of 320,051 homicidal, overdosing-substance-abusing, sex offending, and suicide-completer persons over 95 years consistently replicating these prior results. Most of the at-risk study groups had elevated SP, BSS, and MMPI/MMPI-2/MMPI-A scores [lie/infrequency, depression, psychopathic deviate, paranoia, schizophrenia and addiction (admission or acknowledgement)].

Informed professionals know this often repeated profile. Also, this confirms the often proven notion that actuarial MLIT with $97 \%$ sensitivity and specificity, were an improvement over current ways, which have a combined accuracy and precision of less than chance (39\%). Given that each homicidal, overdosing-substance-abusing, sex-offending and suicide-completer study group case costs about $\$ 1,000,000$ in lost lifetime earnings and considerable grief, actuarial MLIT offer leaders a solution. Based on U.S. 2016 data, 119,965 homicides, mass murder victims, overdosing-substance-abusing, and suicide-completers (FBI, 2012, Zagar, et al., 2016, CDC, 2017, 2018) losses amount to $\$ 119,965,000,000$ (119,965 at $\$ 1,000,000$ each) of lifetime earnings, should not leaders promote wider use of MLIT to save money and lives? The limitations of this study are the small sample size and narrow age, family composition, gender, 
occupation, and racial makeup of the study groups. Despite these impediments, the data are consistent with a "7-point violence profile" for adult and teen, homicidal, overdosing, sex-offending, and suicide-completer study groups. The largest expenses that are incurred by not using MLIT more widely are in psychiatric hospitalization, air transportation suicide victims, criminal athlete and sports club losses, the U.S. Roman Catholic Church pedophilia payouts including lost collections, daily U.S. veteran suicides, and excessive, historically and internationally, the highest imprisonment rate of nonviolent U.S. citizen-taxpaying-voters, who could be moved to electronic monitoring bracelets which cry out to be answered by current leaders. See Table 4.

Table 4. 28 Year (1992-2019 Loss of Lives or Victims and Money in 2019 U.S.

\begin{tabular}{l|l|l|l}
\hline & Sector Over 28 Years & Victims & 28 yrs. loss (2019 US \$) \\
\hline 1 & Over or needless psychiatric inpatient hospitalization & 31,500 & $\$ 4,410,000,000,000$ \\
\hline 2 & Civilian homicides, overdoses, and suicides & $2,458,650$ & $2,485,650,000,000$ \\
\hline 3 & Air, bus, train, and truck transport violence & 8,111 & $245,110,000,000$ \\
\hline 4 & Cumulative daily veteran suicides & 236,870 & $236,870,000,000$ \\
& & & \\
\hline 5 & Professional athlete, coach, owner, and trainer lost revenue from violence & 3,000 & $55,952,733,308$ \\
\hline 6 & Nonprofit Catholic Church pedophile payouts and lost collections & 36,000 & $55,535,349,691$ \\
\hline 7 & Diverting jailed nonviolent offenders to electronic monitoring & $1,072,628$ & $30,191,026,484$ \\
\hline 8 & Health care worker, professor, teacher, and caretaker violence & 60,000 & $30,000,000,000$ \\
\hline 9 & Police suicides, deaths in- line- of- duty and malfeasance payouts & 9,000 & $10,000,000,000$ \\
\hline 10 & Mass murder or active shooting incidents & 9,000 & $9,000,000,000$ \\
\hline 11 & Energy, coal, electricity, gas, nuclear, oil, petroleum, and solar violence & 47,483 & $4,748,300,000$ \\
\hline 12 & Military homicides and suicides & 12,450 & $124,500,000$ \\
\hline & Total & $3,989,552$ & $\$ 7,575,181,909,483$ \\
\hline
\end{tabular}

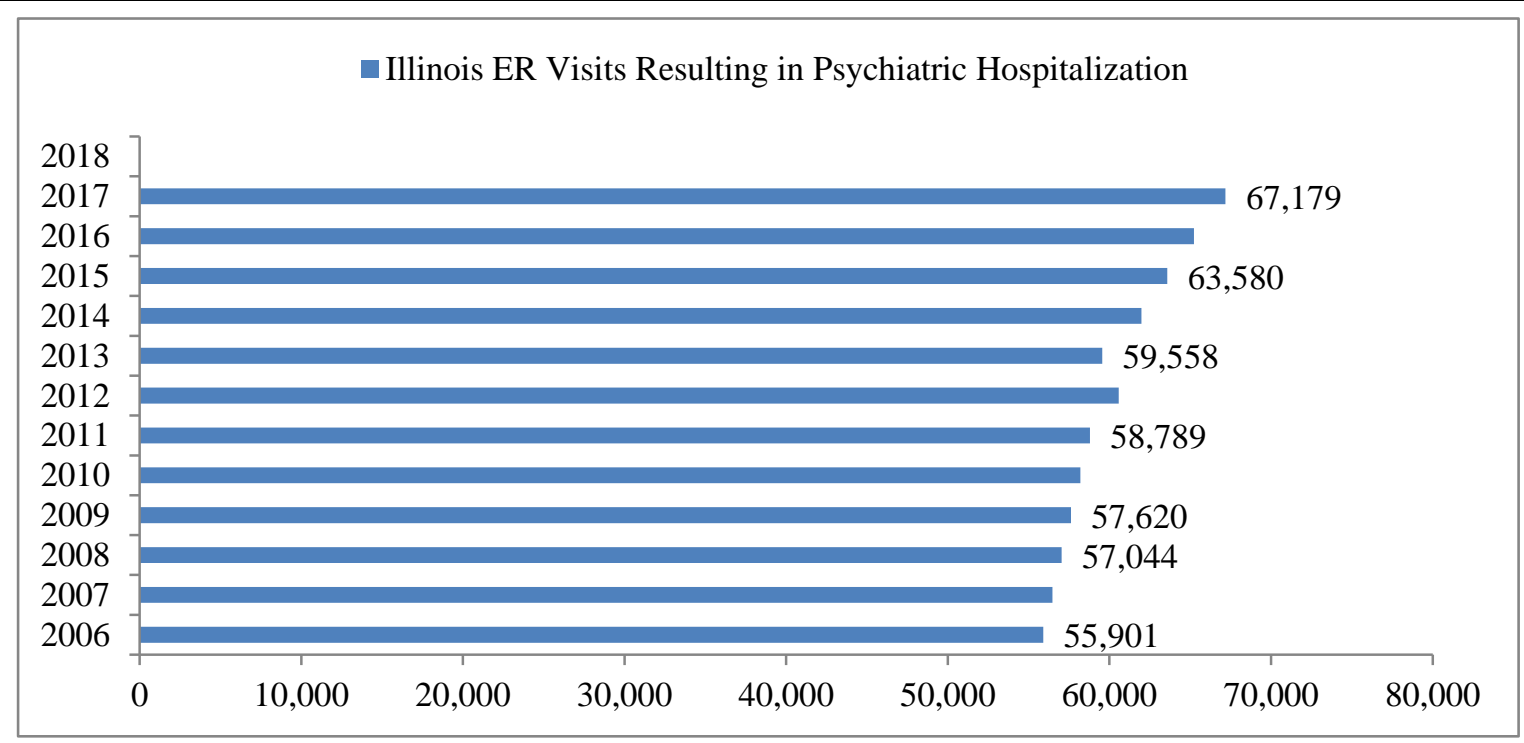

Figure 6. Illinois Psychiatric ER Visits Resulting in Hospitalization Costing $\$ 391,307,000$ (2006) and $\$ 428,253,000$ (2017) [(Dresden, et al., 2016].

There were: 1) the psychiatric hospitalization avoided due to insensitive nonspecific diagnosis by using MLIT; (2) the civilian homicides, overdoses and suicides; (3) the air, bus, train, truck transport; cumulative daily and yearly veteran suicides; (4) the cumulative daily veteran suicides; (5) the professional athlete, coach, trainer lost earnings and sports owners lost revenue; (6) the nonprofit religious pedophilia payouts and lost collections; (7) the jailing and imprisoning nonviolent offenders rather than electronic monitoring; (8) the health care worker physician professor teacher caretaker losses from violence; (9) the public safety suicides, deaths in line of duty and malfeasance payouts; (10) the mass murder or active shooting incidents; (11) the energy (coal, electricity, nuclear, oil, petroleum, solar) losses from violence; and (12) the military homicides and suicides. 


\subsection{Psychiatric Inpatient Hospitalizations Avoided}

At-risk people come to hospital Emergency Rooms (ERs). In 2014, there were 136,300,000 ER visits. Over 10\% $(16,200,000)$ resulted in hospitalization. Just over $10 \%$ of those hospitalized made up the $2,100,000$ psychiatric hospitalizations. The average psychiatric hospitalization cost increased 21\% from $\$ 5,800$ in 2003, to $\$ 7,000$ in 2019. Compared with maternal neonatal, medical, surgical, and injury hospital stays, the psychiatric hospitalization was the longest (Weiss, Barrett, and Steiner, 2014). A short psychiatric ER visit for a medical exam or interview costs $\$ 56$, which is more than all other ER visits. In 2003, the normal length for a psychiatric stay was 6.9 days, which went up to 7.4 days in 2011.

See Figure 6 for the increase in Illinois ER visits from 2006 to 2017. By using MLIT, actuarial assessment and psychiatric patients can be diverted from the hospital ER or soon after admission, lowering the psychiatric inpatient hospitalizations, saving $\$ 214,126,500$ per year, just in Illinois.

Because of the failure to use MLIT in assessing at-risk over the past 28 years, there are 5,880,000 unnecessary psychiatric hospitalizations that cost $\$ 41,160,000,000$. See Table 4. One percent of all health expenditures were for mental health and substance-abuse. In 2009, the spending on substance-abuse prescription medications was $\$ 887,000,000$. Providers for mental health and substance-abuse received $\$ 171,720,000,000$. This can be broken down into $\$ 147,381,000,000$ for mental health. The remaining was spent on substance- abuse. A total of $\$ 10,461,000,000$ was spent for inpatient, outpatient and residential services (U.S. Department of Health and Human Services, 2009; 2014).

\subsection{Civilian Homicides, Overdoses and Suicides}

In 2017, the U.S. annual 21,130 homicides, 66,839 overdoses, 9,832 sex-offenses, and 30,634 suicides sum up to 129,435 yearly violence victims. Since many of these are the result of a long history of mental illness, psychopathology and lack of work, using MLIT to intercept, and divert them to jobs would save lost lifetime earnings, medical, court and jail expenses, that over 28 years, equal 3,799,448 victims at a $\$ 1,000,000$ loss per person or $\$ 3,799,448,000,000$ (Criminal Justice Information Services, 2018).

Table 5. Number of Chicago Youth in Summer Jobs Programs to Divert from Violent Crime Over 10 Years

\begin{tabular}{l|l|l|l|l|l|l}
\hline Year & Program & Number & High Schools & Lives Saved & Mayor & Sponsor \\
\hline 2009 & Culture of Calm & 250 & 6 & 29 & Daley & OJJDP \\
\hline 2010 & Culture of Calm & 1,700 & 38 & 28 & Daley & OJJDP \\
\hline 2011 & Culture of Calm & 1,700 & 38 & 28 & Daley & OJJDP \\
\hline 2012 & Culture of Calm & 1,200 & 32 & 12 & Daley & OJJDP \\
\hline 2012 & 1 Summer Chicago & 1,634 & 13 & 27 & Emanuel & Private Insurance Foundations \\
\hline 2013 & 1 Summer Chicago & 5,216 & 42 & 86 & Emanuel & Private Insurance Foundations \\
\hline 2014 & 1 Summer Chicago & 22,500 & 179 & 86 & Emanuel & Private Insurance Foundations \\
\hline 2015 & 1 Summer Chicago & 24,679 & 186 & 86 & Emanuel & Private Insurance Foundations \\
\hline 2016 & 1 Summer Chicago & 25,000 & 199 & 86 & Emanuel & Private Insurance Foundations \\
\hline 2017 & 1 Summer Chicago & 31,151 & 248 & 86 & Emanuel & Private Insurance Foundations \\
\hline 2018 & 1 Summer Chicago & 32,223 & 256 & 86 & Emanuel & Private Insurance Foundations \\
\hline Total & & 147,253 & 256 & 640 & & \\
\hline
\end{tabular}

Using the research on MLIT actuarial assessment of at-risk, over a decade a teen diversion program in the city of Chicago, first named "Culture of Calm", funded by the U.S. Department of Justice $(\$ 78 \mathrm{M})$ and later called "One Summer Chicago" funded by the insurance companies (Allstate, Liberty Mutual, and State Farm), the Chicago Public Safety Fund and settlements to the city of Chicago has saved 640 lives to date and millions in associated costs [\$1,000,000 lost lifetime earnings or $\$ 640,000,000]($ One Summer Chicago, 2018; Zagar, et al., 2013; 2016). See Table 5 .

Using the same research on MLIT actuarial assessment of at-risk over a decade, the President of Cook County reduced the population of Cook County jails by $56 \%$, diverting mostly nonviolent offenders. U.S. President Obama copied this approach in releasing 6,800 federal prisoners (by commutation or pardon).

This same research on at-risk that showed delinquents do not have executive function or decision making. Using this research, the U.S. Supreme Court in Miller v. Florida and Graham v. Alabama ordered 2,500 life sentences without 
parole juveniles to be re-examined and re-sentenced, often to time served. The Illinois governor along with other governors used this research to begin justice reform in various states. Based on this research, shared with the U.S. President Trump on 29 June, 2015, the Executive Branch and Congress passed the First Step Criminal Justice Reform Bill, which is projected to release $10,000+$ jailed offenders.

7.3 Air, Bus, Train, and Truck Transportation Costs

From 1992 to 2015, there were 911 international and U.S., pilot-assisted, aircraft suicides (CAMI, 2006, 2014).With $\$ 1,000,000$ lifetime earnings loss and a $\$ 1,000,000$ military and airline training expense that is a loss of $\$ 1,822,000,000$. See Figure 7. Bus and truck driver deaths make up $1 \%$ of the 40,000 yearly U.S. roadway fatalities (Toy, 2018). That is 400 lives lost at $\$ 1,000,000$ lost lifetime earnings, which sum up to $\$ 400,000,000$ in annual expenses. Over 30 years the loss is $\$ 1,200,000,000$.

Annually, there are roughly 100 train deaths (Abbott, et al., 2003; Rauti and Dogram, 2004; Weiss and Farrell, 2006). Yearly, these train accidents with a lost lifetime earnings cost of $\$ 1,000,000$ are an expense of $\$ 100,000,000$ that over 30 years cost $\$ 3,000,000,000$. Every year there are 200 large truck accidents which cost $\$ 40,000,000$ each and total to $\$ 8,000,000,000$. Over 30 years that is an expense of $\$ 240,000,000,000$ (Miller, 1997; Zaloshnja, Miller, and Spicer, 2000; National Center for Statistics and Analysis Advanced Research and Analysis, 2003; U.S. Department of Transportation, National Highway Traffic Safety Administration, 2014; Schneider and Palcski, 2018).

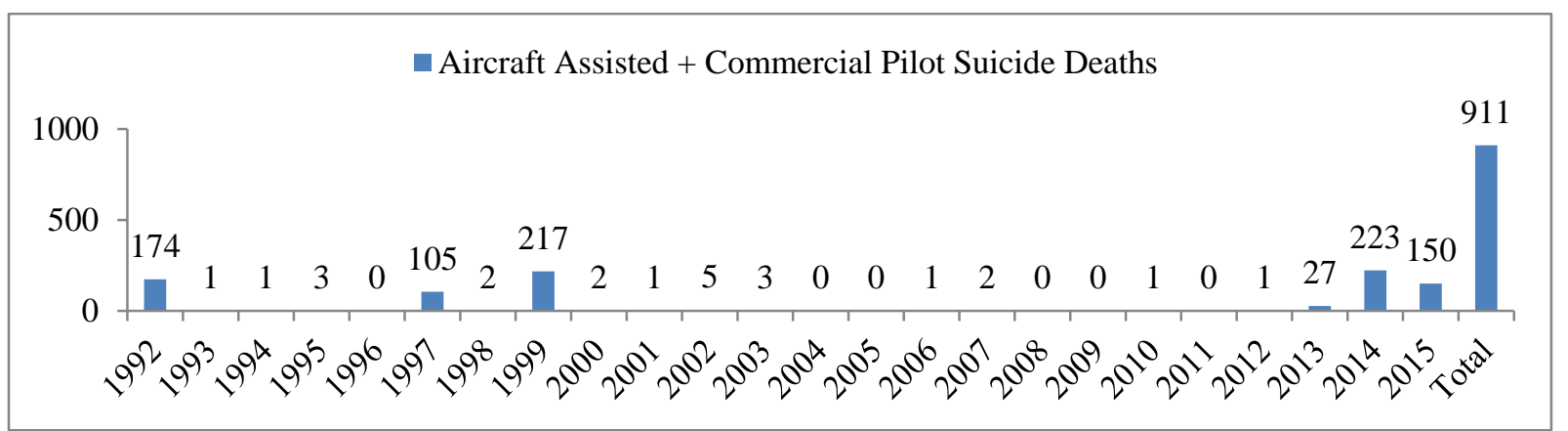

Figure 7. 911 Total 1992-2015 Aircraft Assisted + Commercial Pilot Suicides Costing \$1.822B (CAMI, 2006: 2014)

\subsection{Veteran Suicide Costs}

Each year, 250,000 newly discharged, military join the already 22,000,000 veterans (Kessler, et al., 2014; Army STARRS, 2004-2009; Schoenbaum, et al., 2014; Nock, et al., 2014). Veterans commit violence and have mental illness and substance-abuse challenges.

Among 20,000 veterans, 1-5\% had chronic-fatigue-syndrome, $2 \%$ attempted suicide, 5\% had a suicide plan, 4 to $12 \%$ had post-traumatic stress disorder (PTSD), $11 \%$ were substance-abusers, $14 \%$ were depressed with suicide thoughts, and 25\% had mental illness or behavioral adjustment issues (Kang, et al., 2003). In another study $60 \%$ of veterans were substance-abusing (U.S. Department of Veteran Affairs, Office of the Actuary, 2014).

Among 529,000 veterans, 2\% had PTSD, 10\% were disabled and 19\% mentally ill (Coughlin, et al. 2013; U.S. Department of Veteran Affairs, Office of the Actuary, 2014). See Figure 8 for the 236,870 cumulative veteran suicides from 1990 through 2018 at $\$ 1 \mathrm{M}$ lost lifetime wages and $\$ 1 \mathrm{M}$ lost military training costs equals a $\$ 473.77 \mathrm{~T}$ loss (Zagar, et al., 2016).

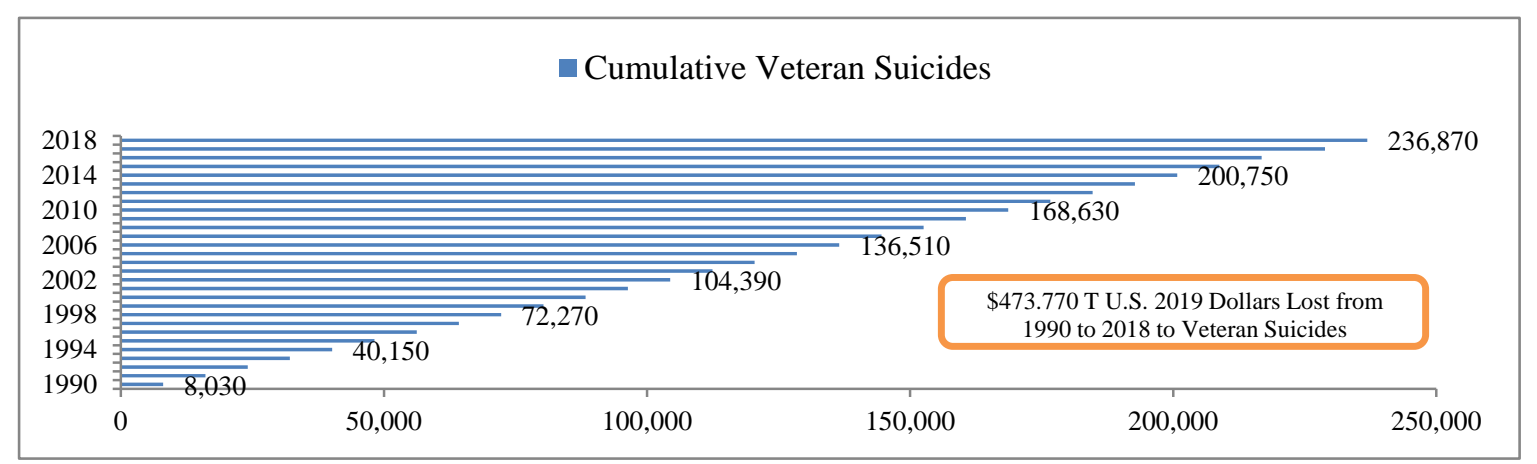

Figure 8. 236,870 Cumulative Veteran Suicides (1990-2018) at \$1M Lost Lifetime Wages \& \$1M Lost Military Training Costs $=\$ 473.740$ T Loss (Zagar, et al., 2016) 
At 22 suicides daily, with 365 days, that is 8,030 veteran deaths yearly. From 1990, when the Desert Storm War in Iraq began, through 2018 as the U.S. continues to fight in Afghanistan, Iraq, Syria and Yemen, the annual 8,030 lost over 30 years, combines to 238,870 veteran suicide deaths. Despite many efforts of this research group to the DOD and VA Suicide Prevention Units, the Secretaries of the Air Force, Army, and Navy, and various generals, this loss continues. Many veterans work in the infrastructure and in public safety, for which this is a significant loss. The military invests at least $\$ 1,000,000$ in training and salary on each, and there are on average, U.S. worker lifetime earnings of $\$ 1,000,000$ to consider. This $\$ 477,740,000,000$ is a loss that is predictable and preventable. To the families and communities, these tragedies are serious matters.

\subsection{Sports Organizations: High School, College and Professional and Athletes}

The loss in revenue, honor, reputation, sales, endorsements, and the effect of violence in sports on the family, the community, and the social fabric cannot be completely given a cost (Zagar, Zagar, Bartikowski, and Busch, 2009), but in Table 4, it is estimated that there are 3,000 victims with a cost of 55,952,733,308. A case study might be the recent professional, football player, homicide case, Hernandez. During Hernandez's college career in Florida, Tebow tried to intervene in a bar fight. During the pre-employment screening of Hernandez, the New England Patriots administered personality tests (Zagar, Zagar, Busch, Garbarino, Ferrari, et al., 2016).

These were consistent with an aggressive, angry and assaulting person, "living on the edge of acceptable behavior." According to Clegg (2013), the football club was cautioned about Hernandez "becoming a problem for the team." Jones (2013) noted that the East Coast professional football club lost $\$ 15,037,000$ in the signing bonus, and took a major hit to their salary cap with his guaranteed salary. Rishe (2013) believed the loss was closer to $\$ 12,700,000$.

An inspection of the expense of violence to sports organizations is crucial. Loss of fans, advertising, sales of memorabilia, and endorsements, are challenging issues to quantify, but others are not. In the Hernandez case, a homicide in 2016 dollars costs $\$ 4,660,986$, while the lost wages of $\$ 15,037,000, \$ 20,000$ in the average felony trial expense, and 57 years in jail, his life expectancy on a life sentence, at the average prison cost of $\$ 27,500$ is $\$ 1,567,500$.

The East Coast team paid $\$ 250,000$ to buy back Hernandez sports shirts, shredding them. So this adds up to a $\$ 19,717,986$ loss. The ultimate tragedy is that Hernandez eventually committed suicide in jail. This is a predictable and preventable loss that could have been avoided with MLIT actuarial assessment, followed up with anger management training, cognitive behavior therapy, and medication and mentoring, as already demonstrated in the decade long Chicago teen diversion "Culture of Calm" and "One Summer Chicago" programs.

A series of sports organization examples follows. Michael Vick lost even more dog fighting. First he lost a $\$ 130,000,000$ contract that was voided. Add the $\$ 20,000$ average felony trial expense and two years at $\$ 27,500$ per year average prison cost, this equals $\$ 55,000$. This totals up to a $\$ 130,075,000$ loss. Generally, costs to victims comprise out-of-pocket expenses for medical bills, property loss, reduced productivity at work, home, and school, and non-monetary losses (fear, pain, suffering, and lost quality of life).

Of course, the intangible loss of quality of life is often much greater, than the tangible or out-of-pocket expenses. Intangible losses are assigned by jury award, and are not predictable. Economists place monetary values on intangible losses in the following categories: productivity; medical care and ambulance; police and fire services; mental health care; social victim service; and property loss and damage (Miller, Cohen, and Wiersema, 1996). For example, the average pedophilia crime costs $\$ 120,681$ in 2012 U.S. dollars. On average, a robbery costs $\$ 9,752$. A fatal crime with assault costs $\$ 3,239,964$.

These expenses do not include punitive damages, but only the portion of awards meant to compensate the victim's pain, suffering, and lost quality of life. These examples demonstrate how experts quantify costs of violence. Recently, Penn State University paid out $\$ 59,700,000$ to 26 victims for pedophilia, at an average award of $\$ 1.6 \mathrm{M}$ to each victim. Jerry Sandusky was a college football coach. The 2016 cost of pedophilia of ten boys is $\$ 124,632$. This all amounts to a $\$ 1,246,320$ loss.

He was 67 at the time of his arrest, and earned an average college football coach salary of $\$ 53,670$ per year for 30 years. The average felony trial expense is $\$ 20,000$ plus $\$ 100,000$ bail. He received a sentence of 60 years at $\$ 27,500$ which equals $\$ 16,500,000$. There was a payout of $\$ 59,700,000$ from Penn State University, so this is a total loss of $\$ 77,446,320$. If one adds the cost of the trials for the former Penn State president and athletic director and their incarceration and the loss in athletic event revenue and reduced alumni donations, this expense increases.

Ohio State may lose $\$ 100$ million for over 50 victims. Baylor University will lose $\$ 223$ million over a sex scandal. Michigan State put aside \$500,000,000 for 324 sexually abused, college athletes, and many Olympic level competitors. A similar situation exists at University of Southern California, where pedophile victims and expense exist. 
Michael Phelps had two driving under the influence arrests (DUIs) at $\$ 88,517$. This equals $\$ 167,034$. He lost $\$ 50,000,000$ in endorsements. The minimum average trial cost of $\$ 20,000$ adds up to a total of $\$ 50,187,034$.

O.J. Simpson is another repeat offending, professional football player, with a double murder, assault, robbery and kidnapping. This cost $\$ 4,660,986, \$ 4,660, \$ 986, \$ 30,850, \$ 23,687$, two felony trials at $\$ 20,000$ or $\$ 40,000,33$ years in jail at $\$ 27,500$ or $\$ 907,500$, and a civil judgment of $\$ 33,500,000$ from the family of homicide victims. This totals up to $\$ 43,824,009$ in 2016 dollars and salaries.

Tom Payne, a professional basketball player, had multiple rape charges at $\$ 124,632$. The mean salary for a National Basketball Association player is $\$ 24,700,000$. A trial costs on average $\$ 20,000$. The 57 years in jail cost, annually at $\$ 27,500$, equal to $\$ 1,567,500$. This adds up to $\$ 26,412,132$ total cost.

Ubeth Urbina, a professional baseball player, was convicted of attempted murder at $\$ 30,850$. The trial cost $\$ 20,000$ and 5 years in prison at $\$ 27,500$, plus the lost average American Baseball League salary of $\$ 17,900,000$, which adds up to a $\$ 18,057,500$ loss.

Rae Carruth, a, married football player, killed his pregnant girlfriend. This is a $\$ 4,660,986$ expense plus the trial cost of $\$ 20,000$. He lost a National Football League mean career wage of $\$ 6,700,000$. He spent 24 years in prison at $\$ 27,500$, which equals to $\$ 660,000$. The total loss is $\$ 12,040,986$.

Oscar Pistorius, the blade runner, killed his wife at $\$ 4,660,986$. The trial cost $\$ 20,000$. There was a bail of $\$ 112,000$ and a 15 year sentence at $\$ 27,500$, which equals $\$ 412,500$. He lost a $\$ 3,000,000$ ad contract. This sums up to $\$ 7,093,486$.

Mark Rogowski, professional skateboarder, murdered, assaulted and raped at a cost of $\$ 4,660,986$. The trial cost was $\$ 20,000$. He lost an average career wage of $\$ 1,200,000$. He spent 31 years in jail at $\$ 27,500$ per year equal to $\$ 852,500$. The total loss is $\$ 6,733,486$.

Sally McNeil, a wrestler, killed her husband at a cost of $\$ 4,660,986$. The trial cost of $\$ 20,000$. She lost an average career wage of $\$ 1,200,000$. She spent 18 years in prison at $\$ 27,500$ yearly equal to $\$ 495,000$. This totals to a $\$ 6,375,986$ loss.

Mike Tyson, a boxer, was convicted of rape at a cost of $\$ 124,632$. He spent three years in jail at $\$ 27,500$ which equals $\$ 82,500$. He lost $\$ 1,000,000$ each year in wages, or $\$ 3,000,000$ total. This adds up to a $\$ 3,144,632$ loss.

Lee Murray, a boxer, robbed $\$ 88,000,000$ with a cost of $\$ 23,687$. He served 25 years in jail. The 25 years in jail at $\$ 27,500$ equals to $\$ 687,500$. He lost a $\$ 75,600$ mean boxing salary, or $\$ 1,894,000$. This is a total loss of $\$ 2,625,187$.

Jonathan Koeppenhauer, a boxer, assaulted three times, and attempted to murder at a cost of $\$ 30,850$ or $\$ 94,400$. There were four trials at $\$ 20,000$ cost each which equal to $\$ 80,000$. He spent two years in jail at $\$ 27,500$, amounting to $\$ 55,000$. The total loss in this case is $\$ 2,041,400$.

Tonya Harding, the ice skater, conspired to assault Nancy Kerrigan at $\$ 30,850$. She lost the mean lifetime salary of $\$ 834,460$. There was a $\$ 20,000$ trial cost. She had a $\$ 100,000$ fine. The total loss is $\$ 985,310$.

The total cost to these 16 athletes is $\$ 417,423,617$. Assuming that sports attendance is the same as church attendance, the lost revenue due to similar criminal activities on ticket sales, and arena revenue for beverages, food and souvenirs over 30 years adding $\$ 417,423,617$ to the pedophilia scandal costs $\$ 55,535,349,691$ equal to $\$ 55,952,773,308$. Imagine the headaches of the sports club owners and athletes' families and the financial heartaches. The total number of college and professional athletes is 465,486 (NCAA, 2018). The professional sports costs may be equal to or greater than those in college athletics.

\subsection{U.S. Roman Catholic Nonprofit Religious Expenses}

The U.S. Roman Catholic Church has 3,000 active seminarians, 16,000 active permanent deacons, 65,000 nuns and monks, 40,000 active priests, and 7,000 Catholic schools with teachers and youth group volunteers with 100,000 school and parish staff. This is a total of 200,000 employees. Worldwide, some $0.5 \%$ to $1.0 \%$ of Catholic, and other nonprofit religious clergy, and teachers regardless of age, education, ethnicity, race, or socioeconomic class, were accused of sexual offenses (Zagar, et al., 2013). Consequently, of the 200,000 employees, there are 2,000 sex offenders. Some estimates are as high as $6 \%$.

In 2007, the total pedophilia liability payout by the U.S. Roman Catholic Church was $\$ 4,520,363,843$ and in 2008, $\$ 436,000,000$. Gallagher Insurance paid out \$1,500,000,000 (Wilhelm, 2012; United States Conference of Catholic Bishops, 2014). Given the current rate of 21 bankruptcies since 1994, among 198 dioceses, the projection is that by 2136, all 198 U.S. Roman Catholic dioceses will be bankrupt. See Figure 9. This is why Pope Francis, after seeing a draft of Zagar, et al., 2016, announced all pedophile moving bishops and cardinals will be removed by canonical court 
and that from February 21-24, 2019, there will be a historic meeting on "the Protection of Minors in the Church."

There is an estimated 9-14\% decline in U.S. Roman Catholic affiliation, due to the pedophilia scandals. The percentage of Catholics in the U.S. population will drop to 0\%, in 500 years.

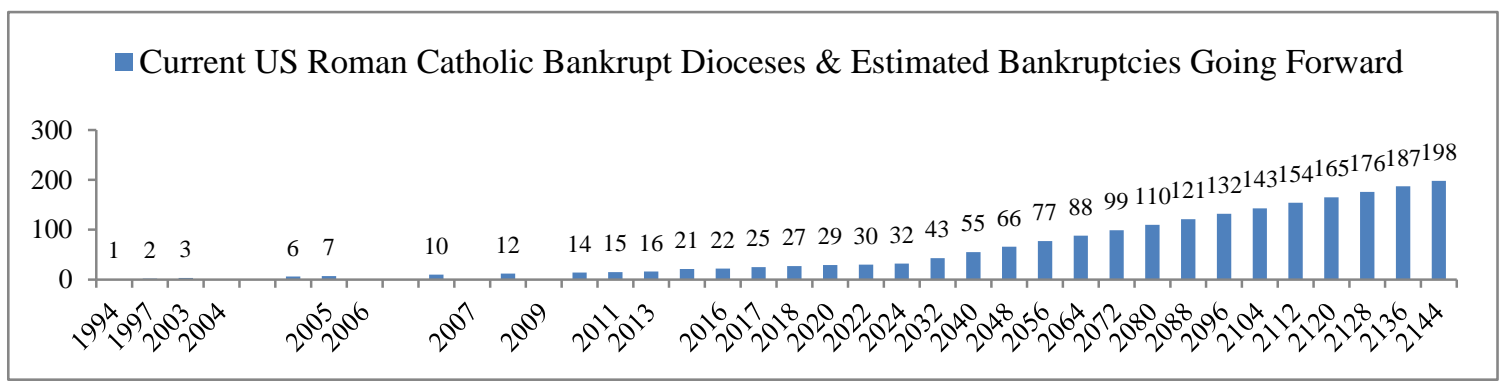

Figure 9. 1994-2016 Projected 198 Bankrupt U.S. Catholic Dioceses From Pedophilia Payouts and Lost Collections (Zagar, et al., 2016)

Given each pedophilia-affected zip code per year, estimated U.S. Roman Catholic loss was $1.3 \%$ in total charitable contributions. Harvard trained economist, Microsoft postdoctoral fellow, University of California San Diego business professor Perez-Truglia [Rotondaro, 2016] computed this annual lost collections and donation revenue. With 1.3\% times 3,000 scandals, the loss is equal to $\$ 1,770,000$ per year.

Non-itemized contributions are $25 \%$ of all giving. Perez-Truglia assumed similar effects on non-itemized givers. A pedophilia scandal costs $\$ 590,000,000$ per year equal to $\$ 1,770,000,000$ plus $\$ 590,000,000$ which equals to $\$ 2,366,000,000$ per year (Ruhl and Ruhl, 2016). Charitable giving does not bounce back.

Economic effects are localized to the area or diocese. Applying the $\$ 2,366,000,000$ loss from 2002-2013 equals to 11 years at $\$ 2,366,000,000$ totaling to $\$ 26,026,000,000$ loss. Add the $\$ 4,520,363,843$ cumulative pedophilia settlements. This amounts to a $\$ 30,546,363,843$ current loss. An example of the current situation, the Chicago Archdiocese just sold the parking lot west of Holy Name Cathedral for $\$ 100,000,000$, a generous price, but the new diocesan chief financial officer notes that there is still a $\$ 200,000,000$ sex abuse debt. This mitigates the problem, but does not solve it. Probably the cardinal's residence and other properties will need to be sold.

Add future U.S Roman Catholic Church pedophilia settlements by applying 1\% to total religious 117,531 using the $\$ 1,130,090$ per pedophile priest in the past, gives $\$ 1,328,985,848$ plus future revenue lost/year, from 2014-2023, at $\$ 2,366,000$ times ten years, equals to $\$ 23,660,000,000$, plus $\$ 1,328,985,848$ totaling $\$ 24,988,985,848$. Past and future loss adds up to $\$ 55,535,349,691$. This is not a rosy financial picture for the 198 U.S. Roman Catholic dioceses and religious groups.

Most recently, federal prosecutors are treating the 198 U.S. Roman Catholic dioceses and university athletic departments as "criminal enterprises." Just as with the jailed former Penn State University president and athletic director, bishops and cardinals, who received probation in the past, will likely face prison terms like the college officials.

MLIT of 117,531 at $\$ 100$ costs $\$ 11,753,100$. We've proposed to the Chicago Archdiocese and the U.S. Roman Catholic Church since 1992 that this objective, reliable, sensitive, specific and valid approach be used with the current ways that miss $69 \%$ of the risk. Hopefully given these facts, there will be a change of heart.

7.7 Releasing Nonviolent Offenders to Electronic Monitoring and Other Diversions

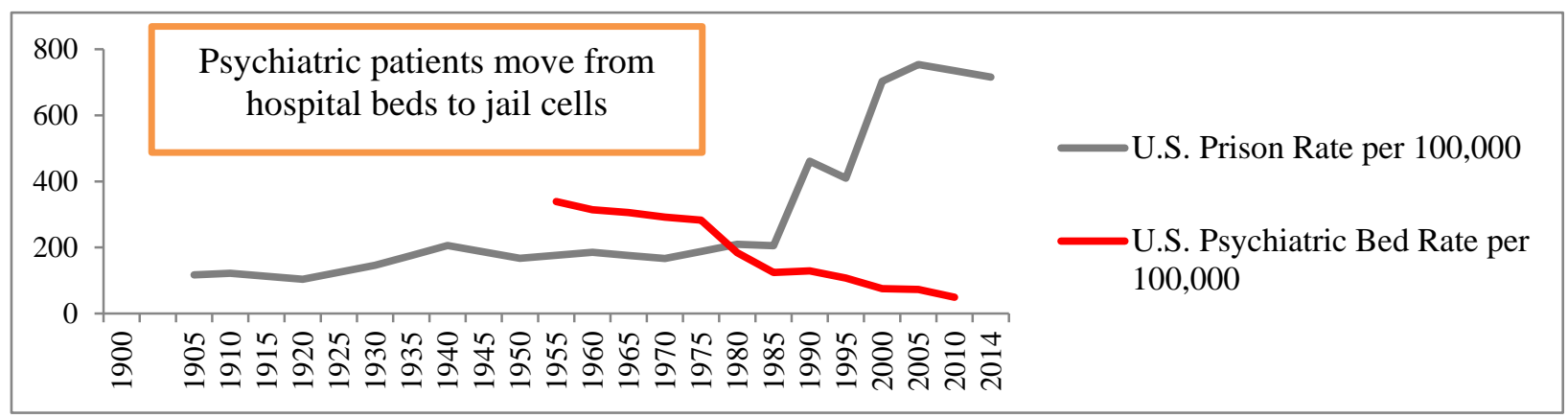

Figure 10. 1095-2015 U.S. Prison Rate vs. Psychiatric Hospital Bed Rate (Zagar, et al., 2016)

One third of the annual cost of crime in the U.S. or $\$ 37,000,000,000$ is the expense of running the U.S. prison system. 
Over time, especially since 1960, there was a movement of psychiatric bed patients to jail cell prisoners. See Figure 10. There is a significant $(p<.01)$ inverse correlation $r=-0.852$ between psychiatric bed cells and imprisoned offenders (U.S. Bureau Justice Statistics, 2014; Statistical Abstract).

Around 1980, the poor without support migrated from psychiatric beds to jail cells. In Cook County, Chicago, Illinois, the County President released 56\% nonviolent offenders to electronic bracelets and other diversions, with no recidivism, or no lowering of community safety (Olson and Taheri, 2012; Zagar, Grove, and Busch, 2013). There is a cost incentive to releasing nonviolent offenders to electronic bracelets or other diversions.

In New York, the annual prison expense is $\$ 3,267,105,290$. Nonviolent prisoners make up $\$ 2,705,422,825$ of that cost. From state to state, the return on investment or ROIs of moving nonviolent offenders to electronic bracelets and assuring the safety of the community by using MLIT tests to screen these prisoners ranges from $\$ 2$ to $\$ 20$. The cumulative savings across 50 states, and the federal prison system, over 28 years, is 30,033,589 offenders or $\$ 845,348,791,552$.

\subsection{Physicians, Health Workers, Teachers, Professors, Counselors, Scout Leaders, Nannies, and Caretakers}

There are at least 191,387 at-risk U.S. physicians, health care workers, occupational, physical and speech therapists, social workers, nurses and psychologists, who commit homicide, overdose-substance-abuse, sex-offend, and commit suicide over 28 years (Statista, 2018; KFF, 2018; Midwife, 2018; Speech Language Pathologists, 2018; Physical Therapists, 2018; Occupational Therapists, 2018; American Psychological Association, 2018; Social Workers, 2018). There are many examples of physicians murdering a domestic partner, nurses killing a patient, overwhelmed therapists overdosing, and health care workers molesting patients. In the current news, a nurse impregnated a comatose patient, who gave birth to a child. The total cost of these risks is $\$ 19,137,230,000$ over 28 years.

\subsection{Public Safety, Police, Firefighters, and Emergency Medical Technicians}

Annually, one of 154 police officials are accused of inappropriate or illegal, violent behavior. One out of 1,549 deaths is caused by public safety personnel, who acted illegally or inappropriately. Among 1,200,000 public safety officers, there are 200 yearly wrongful injury or death claims.

Since 2004, misconduct legal claims against the Chicago Police Department cost $\$ 542,000,000$ (Schroeder, 2016) with 450 current outstanding police misconduct lawsuits. Between January 2009 and November 2011, the City of Chicago treasurer paid out $\$ 455,000$ for 441 lawsuits. This is a rate of $\$ 5.54$ annually for every Chicago city resident.

In Los Angeles the payout rate for police misconduct was half of Chicago's or \$2.66. In New York City was double Chicago's rate or $\$ 9.93$ [Caputo, 2012]. New York City officials paid out $\$ 100,000$ yearly, costing $\$ 1,000,000,000$ in a decade (Fields and Jones, 1999; Fyfe and Kane, 2005).

The combined U.S. annual police suicide and yearly killed-in-the-line-of-duty are 300 (Aamodt and Stainaker, 2006; Badge of Life, 2012; National Law Enforcement Fund, 2015). So, over 30 years that is 7,532 deaths. See Figure 12 for the number of police officers killed and the suicides (Aamodt and Stainaker, 2006; Badge of Life, 2012; National Law Enforcement Fund, 2015).

For every police officer killed or police officer suicide, multiply $\$ 1,000,000$ for the minimum cost of training and replacing that public safety officer, and a lifetime earnings loss of $\$ 1,000,000$. So, 7,532 times $\$ 2,000,000$ is $\$ 15,064,000,000$ (USA Today, 2018). Unwittingly, academics and the media present newspaper articles promoting more mental health services when in fact MLIT, actuarial assessment would not only lower the suicides, but decrease the illegal violent behavior, the killed-in-the-line-of-duty, and the payouts at a fraction of the cost of the current methods of background-credit checks, interviews-judgment, medical exams, and paper-and-pencil tests.

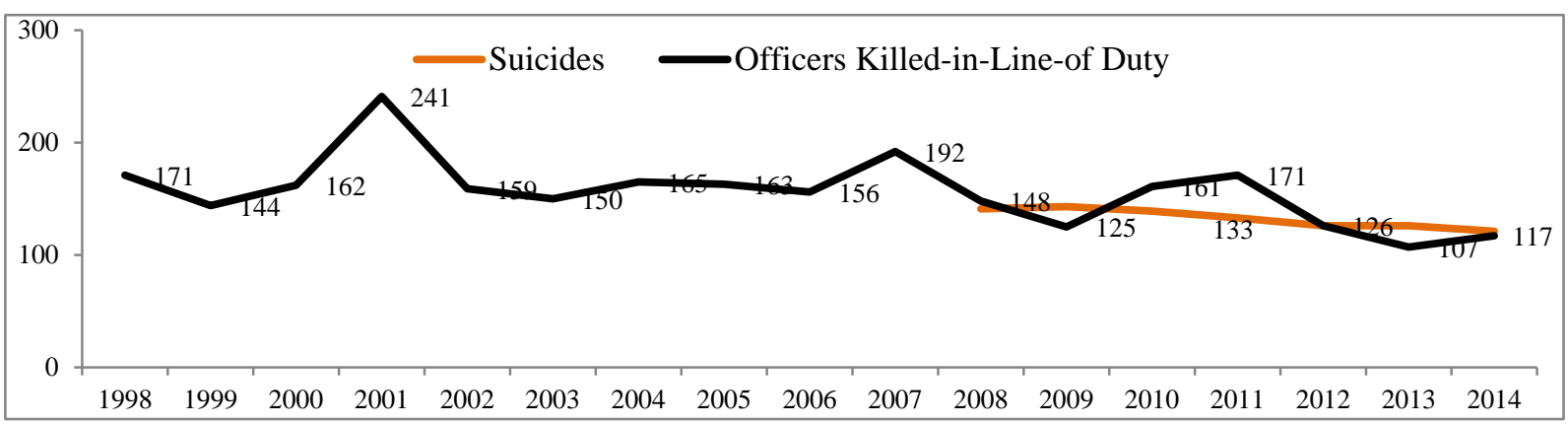

Figure 11. 1998-3013 Annual U.S. Police Officers Suicides \& Killed-in-Line-of-Duty (National Law Enforcement Fund (2015) 


\subsection{Mass Murder and Terrorist Victims Expense}

According to the FBI, from 2000 to 2013, there were 160 active shooters. An active shooter is a person killing or attempting to murder people in a confined, populated area. In contrast, mass murders have at least four victims (Blair and Schweit, 2014). Active shooting incidents have the highest casualties. Among 39 incidents, there were 117 deaths; 40\% committed suicide and 56-66\% had mental illness (Blair and Schweit, 2014). See Figure 12.

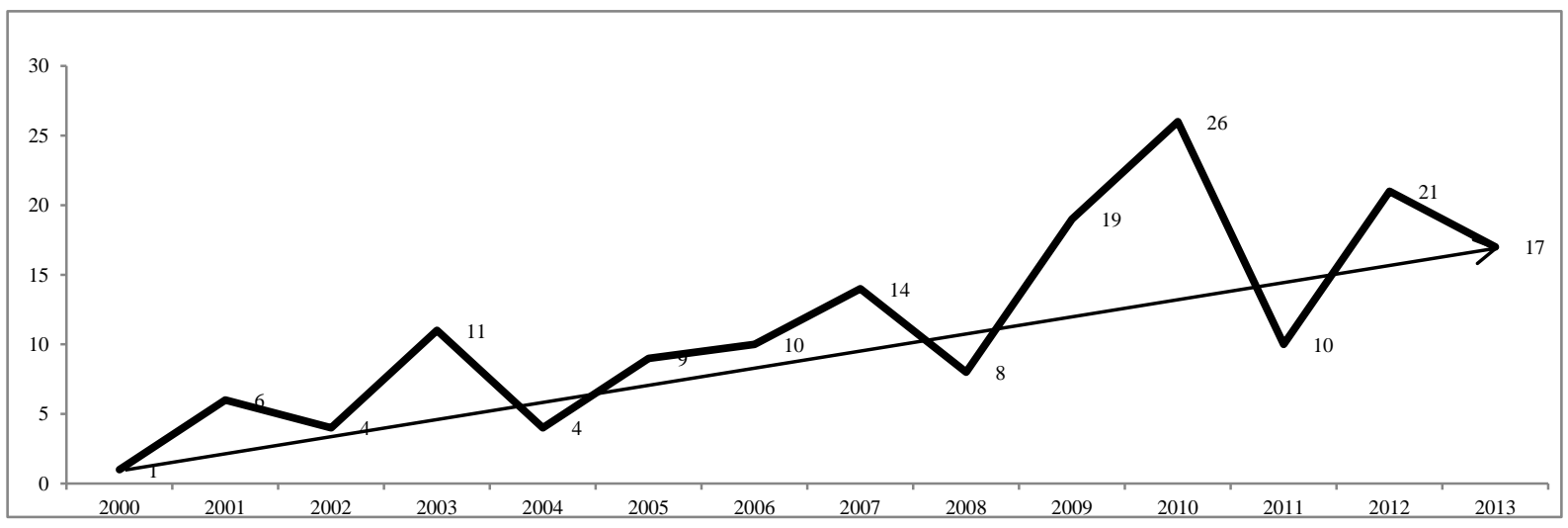

Figure 12. 161 Active Shooter Incidents: 1,046 Dead at \$1M; \$1,047,000,000 Lifetime Lost Wages (FBI, 2014)

Many think that severely mentally ill people are harmless. Indeed, most are. However, some persons with mental health issues commit mass murders, active shooting incidents, suicides and homicides. Their violent actions are related to personal mental health problems in $20 \%$ to $59 \%$ of the incidents studied.

In the year following the Sandy Hook Connecticut School massacre, there were 30 mass shootings with 100 victims. In 2013, there were 300 mass murders; $59 \%$ of these mass murderers had psychiatric illness.

Over 50 years Hempel, Meloy and Richards (1999) studied 30 mass killings, finding 66\% were psychotic in the half century of data examined. From 1949 to 1999, Fessenden (2000) showed 50\% of 100 active shooters had serious mental health challenges. Follman, Aronsen, and Pan (2012) discovered $61 \%$ of active shooters displayed mental health issues from 1982 to 2012. In summary, from 50-66\% of active shooters or an average (M) of 59\% had psychiatric illness (Welch and Hoyer, 2013; FBI, 2014).

\subsection{Energy (Coal, Electricity, Gas, Nuclear, Oil, Petroleum, and Solar}

4,000 U.S. nuclear power plant controllers supply $20 \%$ of the electricity. The probability of a depressed or suicidal controller is ample reason to consider MLIT tests (Bostok and Daley, 2007). In the past, the senior author personally examined a cluster of three completed suicides at a Midwestern nuclear plant.

There are about 600,000 workers involved in the various sectors of energy production (Bromet, Dew, Parkinson, and Schulberg, 1988; U.S. Energy Information Administration, 2009; U.S. Nuclear Regulatory Commission, 2013). There are 474,830 U.S. energy workers, and over 28 years, 25,552 commit homicide, overdose-substance-abuse, sex-offense or suicide, with lifetime earning loss of $\$ 1,000,000$ or $\$ 1,012,000,000$ in total loss (Statista, 2018). If one adds the military training expense, since most energy workers are veterans, this loss is doubled.

\subsection{Military Homicide and Suicide Costs}

Within the military, there were psychiatric, substance-abuse and violence issues. In 2006, after boot camp training, the U. S. Army had a rejection rate of 1,472 of 43,574 recruits. Nineteen percent of these recruits were discharged for unidentified psychiatric issues. One point two percent of U.S. Marines were discharged because of substance-abuse. One percent of enlisted recruits dropped out. Recruitment interviews were consistent with $13.9 \%$ soldiers considering suicide, $5.3 \%$ with a suicide plan, and $2.4 \%$ attempted suicide, with between $47-60 \%$ of these cases existing prior to joining the military. See Figure 13.

Often, PTSD issues led to suicide (Davidson, Hughes, Blazer, and George, 1991). In 2006, the joint forces officers had recruits, with an overall accession rate of only $46 \%$, meaning a $54 \%$ dropout rate. In 2008 , the joint forces, Reserves, and National Guard had 196,000 trainees and 1,450,000 enlisted (U.S. Department of Defense (USDOD), AMSARA, 2009a, 2009b, 2009c).

Costly offenses are perpetrated by military personnel. In 2004, there were 1,798 sexual assault claims, of which 672 resulted in punitive damages (USDOD Sexual Assault Prevention and Response, 2006). Thirty-two percent of enlisted women felt sexually harassed (Bostok and Daley, 2007). This could be explained by the fact that 13\% of U.S. Navy 
enlisted men had committed sexual assault prior to service (Stander, Merrill, Thomsen, Crouch, and Milner, 2008). There were 506 homicides and suicides in the military (Zagar, et al., 2016) over 28 years with a total expense of $\$ 1,012,000,000$. See Figure 13 for military homicides, mass murders and suicides.

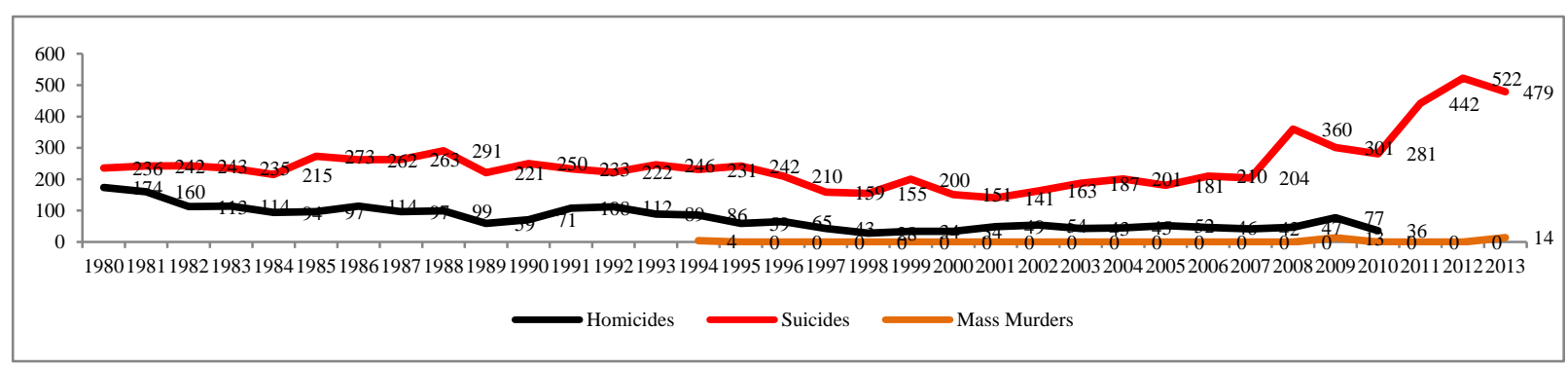

Figure 13. U.S. Department of Defense (DOD) Military 1980-2013 Homicides Suicides and Mass Murders

\subsection{Action Plan: Presidential Executive Order and/or Papal Directive Action Plan}

So the action plan to begin to save lives and expense on these twelve sectors follows.

\subsubsection{Psychiatric Over-Hospitalization}

On a practical level, the U.S. President can call and set up a meeting. There would be the CEO and CFO of Blue Cross Blue Shield of Illinois, the neurosurgeon leader of the Department of Housing and Urban Development, the Exelon CEO Northwestern Memorial Hospital Board of Directors, physician head of the Emergency Department, and the Northwestern Memorial Hospital President, who could devise a plan to begin using actuarial MLIT in the emergency room and hospital. Savings are in the hundreds of millions in Illinois alone, and trillions in the U.S.

\subsubsection{Civilian Homicides, Overdoses, and Suicides}

The U.S. President could offer the Chicago and Illinois insurance executives combined with the political leaders, the Chicago mayor and county president, a grant of $\$ 50$ to $\$ 100$ million to start a project that modelled the Obama "Culture of Calm" \$78M Department of Justice grant. The focus would be jobs, anger management, and mentoring for adult gang members that are Milted, and then given jobs planting trees for the Park District, repairing potholes for the Department of Transportation, painting infrastructure, or working in the Department of Streets and Sanitation. Chicago's homicide rate would drop.

\subsubsection{Air, Bus, Train, and Truck Transport Deaths}

The U.S. President could by executive order ask the Federal Aviation Administration to require all pilots, air traffic controllers, flight attendants, airplane mechanics and TSA agents, as part of the medical exam for job entry and promotion, to take MLIT, thereby identifying overdosing-substance-abusing, sex-offending and suicide-completers, before a possible fatality. By doing the same in the Interstate Commerce Commission, the American Truckers Association, the Transportation Department and other federal agencies, the U.S. President could require the same of interstate bus drivers, tank truck operators, especially railroad engineers transporting volatile fluids. Transportation injuries and deaths would decrease dramatically.

\subsubsection{Cumulative Daily, Yearly and Decades Long Veteran Suicides}

The U.S. President with executive order can direct the Head of the Veterans Administration to require Lovell Hospital at Great Lakes Naval Base in North Chicago Illinois, a conjoint private military, Navy and veterans facility to begin using the MLIT in the emergency room and clinics for veterans reluctant to admit weakness, after serving bravely in wars to identify homicidal, overdosing-substance-abusing, sex-offending, but most importantly suicide-completers. The model from the psychiatric over-hospitalization and military-private-veteran Lovell Hospital could be shared with all U.S. hospitals. A significant decrease in veteran suicides would result.

\subsubsection{Professional Collegiate and Olympic Athlete, Coach, and Trainer and Scouting Crimes \& Sex-Offending}

The U.S. President could call together first a meeting of the National College Athletic Association, then the Olympic Committee, then the professional organizations for baseball, basketball, football, hockey, and soccer to discuss how to safeguard the country, and the profitability of college and professional sports, and their impact on future youth by using MLIT with medical exams, to not only protect the players from themselves, but also the owner's investment. The President could bring in the head of the Boy and Girl Scouts and suggest that they use medical exams and MLIT with all scout leaders. Owners and athletic directors would see payouts decrease and profits rise. 


\subsubsection{Nonprofit, Religious Groups Pedophilia Payouts and Lost Collections}

The U.S. President, working with the Pope, could within a year call a meeting in Chicago. In Chicago, the President could use the hotels and convention halls to bring together the government and business heads to accomplish adding MLIT to current ways. The Pope could promote the use of MLIT with current methods for intake in seminaries and promotion of religious and nonprofit teachers by having a convention at Vincentian DePaul and Jesuit Loyola Universities, who have available campuses and dormitories during the summer. Financial and legal jeopardy would be avoided.

\subsubsection{Diverting Nonviolent and/ or Mentally Ill Offenders to Electronic Monitoring Bracelets and Other Diversions}

The U.S. President can call a meeting of the county presidents, governors and mayors, and suggest that MLIT be used in cities, counties and states at intake and release of offenders from jail or prison, and demonstrate that nonviolent offenders moved to electronic bracelet monitoring or other diversions, saves valuable taxpayer funds for other needs such as infrastructure, health and education. There would be a significant drop in the Chicago homicide rate.

\subsubsection{Health Care Workers, Physicians, Professors, Teachers, and Caretaker Violence}

The U.S. President could work with the insurance companies and emergency room department heads of the various hospitals. He could leverage his advantage of increasing profits for both, and work with military and veteran hospitals to give an executive order to screen all health workers in federal government positions by taking MLIT as part of the intake and promotional medical exam.

\subsubsection{Public-Safety, Personnel Suicides, Deaths-in- the-Line-of-Duty, \& Malfeasance Payouts}

The U.S. President may use executive order and find federal grant money to begin first with Chicago and then New York to offer funds to add MLIT to current ways of intake of new police, fire and emergency medical technician cadets, and the promotion of public safety personnel to lower malfeasance, killed in the line of duty, and suicide completion.

\subsubsection{Mentally Ill Mass Murderers or Active Shooters}

Using presidential suggestion and executive order, MLIT could be used in gun and rifle screening for employees at overseas State Department embassies since the tests are available in many languages. Also, MLIT could be used in screening of immigrants with a criminal or medical history.

\subsubsection{Energy Worker (Coal, Electricity, Nuclear, Oil, Petroleum, and Solar Violence}

A presidential executive order could focus on the Nuclear Regulatory Commission and Energy Department, to improve safety of workers in various energy sectors.

\subsubsection{Military (Including National Guard and Military Academies) Homicides and Suicides}

The U.S. President as Commander-in Chief can order the military base in Illinois to start using MLIT in draft and enlistment programs.

\subsubsection{Conclusion and Summary}

The bottom line is that without leadership, MLIT cannot safeguard communities. There is hope for a safer world and a peaceful next generation, because with probability models, namely actuarial assessments, there is the potential for violence prediction or forecasting because one collects the full information in a MLIT. Amazingly, this is based on nearly a century of data incorporating a few hundred studies, on nearly a third of a million persons, over many continents and countries, where violence was predicted in many independent trials, which give relevant quantified values from which the probability of the future can be predicted in a "7-point violence profile". This is based on limited data from the past, to predict or forecast future violent behavior. Thus, MLIT and professionals who use them, are witnesses for hope of a safer, peaceful world, where families can raise children, who go to school and places of worship, and then find gainful jobs to continue the cycle, peacefully and safely.

\section{Acknowledgement}

Authors thank Professor Jack Arbit, Neurology Department, Loyola and Northwestern University Medical Schools, Professor John Russell Hughes, M.D., Ph.D., D.Sc. (Oxon)., Professor Michael Garanzini, Ph.D., S.J., President of 200 International Jesuit Universities, Former President, Loyola University of Chicago, Professor Boris Bartikowski, Euromed Management, Marseille, Professors Jim N. Butcher and William Grove, University Minnesota Twin Cities, Professors Mike Marasco, and Bob Shaw, Robert Farley Entrepreneurship Center, McCormick School of Engineering and Kellogg School of Management, Northwestern University, Northwestern graduate students, Dave Beseda, Neeta Boga, Mike Dinnon, Scott Eisfeldt, Pete Gariepy, Roopa Natarajan, Kristin Powell, Arshad Syed, Jake Wilson, Ling Wang, and Lei Zhao, Professor Alan Mead and Roya Ayman, Industrial Psychology Organizational Behavior 
Department, Illinois Institute of Technology (IIT), IIT graduate students, Mike Zablocki, Bill Osnowitz, Jonas Neuhengen, and Yutong Liu, Professor Dan Lowery, Brother Ben Basile, Professors Tina Ebinger and Michael Spiccia, Calumet College of Saint Joseph, Professors Fred Bryant and Mike Garanzini, S.J., and Seminary Rector Kevin, Flaherty, S.J., Loyola University at Chicago, Lakeshore Campus, Professor King and Professor Cooke, University of Illinois at Chicago Business College, Professor Joel Milner, Child Abuse Potential Questionnaire, Psychology Department, Northern Illinois University, Judy Perkinson, Aurelio Prifitera, Tina Sheldon, Pearson Assessment, Stephanie Ammons Isbell, Marni Ammons, Ammons Scientific, Lawyers Randy Stark, and Brooke Whitted, Chief Hearing Officer Nancy Hablutzel, James Cardinal Harvey, Francis Cardinal George, Joseph Cardinal Ratzinger, Karol Cardinal Wojtila, Sean Cardinal O’Malley, Pope Francis, Most Reverend Thomas J. Paprocki, Most Reverend Blaze Cupich, Scott Trubow, Olympia Laboratory, Lieutenant Colonel Scott Johnson, Lieutenant Colonel Mike Stewart, Glen Miller, Ph.D., Substance Abuse and Subtle Screening Inventory Institute, Springville, Indiana, Air Canada Pilots Robert Warman and Bob Fenn, Barrister, American Airline Pilot Lieutenant Colonel Paul McKay, Bob Seritella, Exelon Nuclear Power, Chicago, Tom Adamski, First One Logistics, New Jersey, Bobby Skafish, Jim Doherty, Dan Drzezinski of Affiliated Media, Programmer Wyatt Sutherland, Peter Perscuitti, Gallagher Insurance Nonprofits and Religious, Pat Neal, Virtus, Generals of the U.S. and Illinois Army and Air Force National Guard, Jesse White, Illinois Secretary of State, Chicago City Aldermen Abroyas, Burke, Osterman, Sawyer, and Villegas, Illinois Appellate Court Judge Anne Burke, Chicago Mayors Emanuel, Daley and Daley Sr., Presidents Bush, Clinton, Obama and Trump, Speakers Boehner, Gingrich, Hastert, Eric O'Keefe, Mrs. Laura Arnold, Arnold Foundation, Edith Schiller Neurology Fund, Neurology and Psychiatry Department, Northwestern University, Cook County Circuit Court Judges Julia Quinn Dempsey and Chief Judge Arthur Hamilton, Robert E. Bussell, M.D., Juvenile Division Cook County Circuit Court for providing data. Senior author funded the current analysis. We thank clergy, military, patients, prisoners, students, and workers, children and families for making the world safe and secure, volunteering time and energy to this project and the Omilian, Pikul, Szkotak, Zagajewski, and Zagar families for support. Thanks to Bobby Skafish, Jim Doherty, Dan Drzezinski. Presented at: (a) U.S. House Representatives, Judiciary Subcommittee Crime, Terrorism, and Homeland Security Hearing, Rayburne Building, 24 July 2012, Washington, D.C. with Virginia's Representative Bobby Scott and Michigan's Representative John Conyers accessed at: https://www.youtube.com/watch?v= AHUEJ1lwoTo\&list=UUdNNcpw8arCsUp55Jwk QAA minute 19 \& at end; (b) Polish American Action Committee to Illinois Governor Rauner, December, 8, 2013; (c) Society of American Military Engineers (SAME) and The Infrastructure Partnership (TISP) Conference, 8 April 2014 Colorado Springs, accessed at: http://www.tisp.org/index.cfm?pid=13346; (d) Illinois Psychological Association, 6 November 2015, Skokie, Illinois; (e) Association for Psychological Sciences, May 27, 2016, Sheraton Hotel, Chicago, Illinois; (f) Chicago School of Professional Psychology, March, 17, 2017, Marriott Hotel, Chicago Illinois; (g) Chicago City Council, Public Safety Hearing, April, 4, 2017; (h) Illinois State Legislature Black Caucus, December, 8, 2017; (i) 14 February, 2018, Gary Diocese, and Psychology Department, Calumet College of Saint Joseph, Whiting, Indiana. Internet-based tests available through Pearson Assessment .com, (MMPI-2/A personnel version or clinical interpretative report, MMPI-RF report, Raven, and Beck) at 1-800-627-7271 and Testrac.com, (ART, LLC: Ammons Quick Test, Raven, Beck, and Standard Predictor report) at 952-953-6292 or dbodell@testracom.

\section{References}

Aamodt, M. G., \& Stainaker, N. A. (2006). Police officer suicide: Frequency and officer profiles. Policeone.com News. http://dx/doi/org/10.5539/par.v2n1p84

Abbott, R., Young, S., Grant, G., et al. (2003). Railway suicide: An investigation of individual and organizational consequences. A report of the suicides and open verdicts on the Railway Network Project. Doncaster, U.K.: Doncaster and South Humber Healthcare NHS Trust.

Advokat, C., Eustis, N., \& Pickering, J. (2005). Relationship between diagnosis and disposition of patients admitted to a state psychiatric hospital. Psychiatric Quarterly, 76, 97-106.

American Psychiatric Association. (2013). Diagnostic and statistical manual of mental disorders (5th ed., text rev.). Arlington, VA.: American Psychiatric Association Publishing.

American Psychological Association [APA] (2018). How many psychologists are registered in the US? Retrieved from: https://www.apa.org/monitor/2014/06/datapoint.aspx

Ammons, R. B., \& Ammons, C. H. (1962). The Quick Test (QT): provisional manual. Psychological Reports, 11, 111-162. (Monograph Supplement 7-VII)

Anderson, W. P., Kunce, J. T., \& Rich, B. (1979) Sex offenders: Three personality types. Journal of Clinical Psychology, 35, 671-676. https://doi.org/10.1002/1097-4679 (197907)35:3\%3C671::AID-JCLP2270350335\%3E3.0.CO;2-O 
Andrews, D., Kiessling, J., Robinson, D., \& Mickus, S. (1986). The risk principle of case classification: An outcome evaluation with young adult probationers. Canadian Journal of Criminology, 28, 377-384. https://doi.org/10.1177\%2F0306624X05282556

Archer, R. P., \& Slesinger, D. (1999). MMPI-A patters related to endorsement of suicide ideation. Assessment, 6, 51-60. https://www.ncbi.nlm.nih.gov/pubmed/9971883

Armentrout, J. A., \& Haure, A. L. (1978). MMPI's of rapist of adults, rapists of children and non-rapist sex offenders. $\begin{array}{lllll}\text { Journal of } \quad \text { Clinical } & \text { Psychology, } & 330-332 .\end{array}$ https://doi.org/10.1002/1097-4679(197804)34:2<330::AID-JCLP2270340213>3.0.CO;2-R

Babst, D. V., \& Mannering, J. W. (1965). Probation versus imprisonment for similar types of offenders: a comparison by subsequent violations. Journal of Research in Crime and Delinquency, 2, 60-71. https://www.ncjrs.gov/App/Publications/abstract.aspx?ID=49813

Badge of Life. (2012). A study of police suicides 2008-2012. Retrieved from http://www.policesuicidestudy.com Basham, R. B. (1992). Clinical utility of the MMPI research scales in the assessment of adolescent acting out behaviors. Psychological Assessment, 4, 483-492. http://psycnet.apa.org/doi/10.1037/1040-3590.4.4.483

Beck, A. (1978). Beck Depression Scale. Philadelphia, PA: Center for Cognitive Therapy.

Beck, A. (1991). Beck Suicide Scale. Philadelphia, PA: Center for Cognitive Therapy.

Beck, A. T., \& Steer, R. A. (1981) Manual for the Beck Scale for Suicide Ideation. Psychological Corporation, San Antonio, TX.

Beck, A. T., Kovacs, M., \& Weisman, A. (1975). Hopelessness and suicidal behavior. Journal of American Medical Association, 234, 1146-1149.

Biro, M., Vuckovic, N., \& Djuric, V. (1992). Towards a typology of homicides on the basis of personality. British Journal of Criminology, 32, 361-371. https://www.ncjrs.gov/App/Publications/abstract.aspx?ID=138501

Blair, J. P., \& Schweit, K. W. (2014). A study of active shooter incidents in the U.S. between 2000 and 2013. Texas State University and Federal Bureau of Investigation, U.S. Department of Justice, Washington, DC. http://dx.doi.org/10.1016/S0140-6736 (15)60891

Bonta, J., \& Motiuk, L. L. (1985). Utilization of an interview-based classification instrument. Criminal Justice and Behavior, 12, 333-352. http://psycnet.apa.org/doi/10.1177/0093854885012003004

Bonta, J., Harman, W. G., Hann, R. G., \& Cormier, R. B. (1996). The prediction of recidivism among federally sentenced offenders: a revalidation of the Statistical Information on Recidivism Scale. Canadian Journal of Criminology, 38, 61-79. https://www.ncjrs.gov/App/Publications/abstract.aspx?ID=160106

Borden, H. G. (1928). Factors for predicting parole success. Journal of Criminal Law and Criminology, 19, 328-336.

Bostok, D. J., \& Daley, J. G. (2007). Lifetime and current sexual assault and harassment victimization rates of active duty U.S. Air Force women. Violence against Women, 13, 927-944. http://dx.doi.org/10.117/1077801207305232

Brad, C. A., Coupland, R. B. A., \& Oliver, M. E. (2014). An examination of mental health, hostility, and typology in homicide offenders, Homicide Studies, 1-19. https: dx.doi:10.1177/1088767914521416.hsx.sagepub.com

Briley, J. (2001). The uninvestigated factors: Dimensions of personality and psychopathology in sex offenders. Master's thesis at University of North Texas. Retrieved from: http://citeseerx.ist.psu.edu/viewdoc/download?doi=10.1.1. 590.3488\&rep=rep1\&type=pdfof $\quad$ Science (Psychology),

Bromet, E. J., Dew, M. A., Parkinson, D. K., \& Schulberg, H. E. (1988). Predictive effects of occupational and mental stress on mental health of a male work force. Journal of Organizational Behavior, 9, 1-13. http://dx.doi.org/10.1002/job. 4030090102

Bueno-de-Mesquita, J. M., Nuyten, D. S. A., Wesseling, J., van Tinteren, H., Linn, C. S., \& van de Vijver, M. J. (2009). The impact of inter-observer variation in pathological assessment of node-negative breast cancer on clinical risk assessment and patient selection for adjuvant treatment. Annals of Oncology, 21, 40-47. http://dx.doi.org/10.1093/annonc/mdp273

Burgess, E. W. (1928). Factors making for success or failure on parole. In A. A. Bruce, E. W. Burgess, A. J. Harno, \& J. Landesco (Eds.), The workings of the indeterminate sentence law and the parole system in Illinois. Springfield, IL: State Board of Parole.

Burgess, E. W. (1929a). Is prediction feasible in social work? Social Forces, 8, 533-545. 
Burgess, E. W. (1929b). Predicting success or failure upon release from state institutions. Journal of Juvenile Research, 13, 270-284.

Busch, K. G., Zagar, R. J., Grove, W. M., Hughes, J. R., Arbit, J., Bussell, R. E., \& Bartikowski, B. (2009). Looking forward in records of young adults convicted of sexual homicide, rape or molestation as youth: Risks for reoffending. Psychological Reports, 104, 155-184. http://dx.doi.org/10.2466/PR0.104.1.155-184

Butcher, J. N. (1996). International adaptations of the MMPI-2. Minneapolis, MN: University of Minnesota Press.

Butcher, J. N., \& Pancheri, P. (1976). Handbook of cross-national MMPI research. Minneapolis, MN: University of Minnesota Press.

Butcher, J. N., Dahlstrom, W. G., Graham, J. R., Tellegen, A., \& Kaemmer, B. (1989). Minnesota Multiphasic Personality Inventory Second Edition manual for administration and scoring. Minneapolis, MN: University of Minnesota Press.

Butcher, J. N., Gucher, D. K., \& Hellervik, W. (2009). Clinical personality assessment in the employment context. In J. N. Butcher (Ed.), Oxford Handbook of Personality Assessment. Oxford, U.K.: Oxford University Press. Pp. 582-597.

Caputo, A. (2012). Abusing the badge. Chicago Reporter. Retrieved from http:chicagoreporter.com/news/2012/05/abusing-badge

Carlson, K. (1973). Some characteristics of recidivists in an Ontario institution for adult male first incarcerates. Canadian Journal of Criminology and Corrections, 15, 397-409.

Carmin, C. N., Wallbrown, F. H., Ownby, R. L., \& Barnett, R. W. (1989). A factor analysis of the MMPI in an offender population. Criminal Justice \& Behavior, 16, 486-494. https://doi.org/10.1177\%2F0093854889016004008

Carney, F. (1967). Predicting recidivism in a medium security correction institution. Journal of Criminal Law,

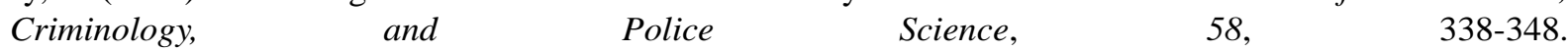
$\mathrm{Https}$ ///scholarlycommons.law.northwestern.edu/cgi/viewcontent.cgi?article=5468\&context=jclc

Carroll, J. S., \& Fuller, G. B. (1971). An MMPI comparison of three groups of criminals. Journal of Clinical Psychology, 27, 240-242. https://doi.org/10.1002/1097-4679 (197104)27:2\%3C240::AID-JCLP2270270227\%3E3.0.CO;2-7

Center for Disease Control (2017). Drug Overdose Deaths in the United States, 1999-2016. Retrieved from: https://www.cdc.gov/nchs/products/databriefs/db294.htm

Center for Disease Control (2018). Suicides rising across U.S. Retrieved from: https://www.cdc.gov/vitalsigns/suicide/index.html

Challinger, D. (1974). A predictive device for parolees in Victoria. Australian and New Zealand Journal of Criminology, 71, 102-106.

Civil Aerospace Medical Institute (CAMI). (2006). Civil Aerospace Medical Institute, medical aspect of findings from aircraft-assisted pilot suicide in the U.S.: 1993-2002. Washington, D.C.: Office of Aerospace Medicine.

Civil Aerospace Medical Institute (CAMI). (2014). Civil Aerospace Medical Institute, Aircraft-assisted pilot suicide in the U.S. 2003-2012. Washington, D.C.: Office of Aerospace Medicine.

Clark, J. H. (1952). The relationship between MMP scores and psychiatric classification of Army general prisoners. Journal of Clinical Psychology, 8, 86-89.

Clegg, J. (2013). An early warning about Hernandez. The Wall Street Journal.

Clemens, R., \& Heinz, J. M. (2010). Diagnostic accuracy and factor structure of the AAS and APS scales of the MMPI-2. Journal of Personality Assessment, 79, 564-582. https://doi.org/10.1207/S15327752JPA7903_10

Clopton, J., \& Baucom, D.H. (1979). MMPI ratings of suicide risk. Journal of Personality Assessment, 43, 296-299. https://doi.org/10.1207/s15327752jpa4303_12

Clopton, J., \& Jones, W. (1975). Use of the MMPI in prediction of suicide. Journal of Clinical Psychology, 31, 52-54. https://doi.org/10.1207/s15327752jpa4303_12

Clopton, J., Pallis, D., \& Birtchnell, J. (1979). Minnesota Multiphasic Personality Inventory profile patterns of suicide attempters. . Journal of Consulting and Clinical Psychology, 47(1), 135-139. http://dx.doi.org/10.1037/0022-006X.47.1.135 
Clopton, J., Post, R., \& Larde, J. (1983). Identification of suicide attempter by means of MMPI profiles. Journal of Clinical Psychology, 39, 858-871. https://doi.org/10.1002/1097

Cornell, D. G., Miller, C. \& Benedick, C. P. (1988). MMPI profiles of adolescents charged with homicide. Behavior Sciences and the Law, 6, 401-407. https://doi.org/10.1002/bsl.2370060308

Coughlin, S. S., McNeil, R. B., Provenzale, D. T., Dursa, E. K., \& Thomas, C. M. (2013). Methodologic issues in epidemiologic studies of medically unexplained symptom-based conditions. Journal of Military and Veterans Health, 21, 4-10.

Coxe, R., \& Holmes, W. (2009). A comparative study of two groups of sex offenders identified as high and low risk on the static-99. Journal of Child Sexual Abuse: Research, Treatment, \& Program Innovations for Victims, Survivors, \& Offenders, 18, 137-153. https://doi.org/10.1080/1053871090274392

Craig, R. J., \& Olson, R. E. (1990) MMPI characteristics of drug abusers with and without histories of suicide $\begin{array}{lllll}\text { attempts. Journal of } & \text { 717-728. }\end{array}$ http://psycnet.apa.org/doi/10.1207/s15327752jpa5503\&4_29

Craig, R. J. (1995). Assessing contemporary substance abusers with the MMPI Mac Andrews Alcoholism scale: A review. Substance Use and Misuse, 40, 427-450. https://www.ncbi.nlm.nih.gov/pubmed/15830728

Craig, R. J. (2005) Assessing Contemporary Substance Abusers with the MMPI Mac Andrews Alcoholism Scale: A Review, Substance Use \& Misuse, 40, 427-450. https://doi.org/10.1081/JA-200052401

Craig, R. J. (2008). MMPI-based forensic-psychological assessment of lethal violence. In H.V. Hall (Ed.) Forensic psychology and neuropsychology for criminal and civil cases. (pp. 393-416). Boca Raton, FL: CRC Press.

Criminal Justice Information Services. (2018). Retrieved from https://www.fbi.gov/services/cjis

Culhane, S. E., Hildbrand, M. M., Walker, S., \& Gray, M. J. (2014). MMPI-2 characteristics of male serial murderers, Applied Psychology in Criminal Justice, 10(1) 21-45. Retrieved from http://dev.cjcenter.org/_files/apcj/apcjspring2014culhane.pdf_1399047242.pdf

Daige, M. (2004). MMPI inmate profiles: Suicide completers, suicide attempters, and non-suicide controls. Behavior Science and the Law, 22, 833-842. https://doi.org/10.1002/bsl.618

Davidson, J. R. T., Hughes, D., Blazer, D. G., \& George, L. K. (1991). Post-traumatic stress disorder in the community: An epidemiological study. Psychological Medicine, 21, 713-721. https://dx.doi.org/10.1017/S0033291700022352

Davis, K. R., \& Sines, J. O. (1971). An antisocial behavior pattern associated with a specific MMPI profile. Journal of Consulting and Clinical Psychology, 36, 229-234. http://psycnet.apa.org/doi/10.1037/h0030739

Davis, K. R., \& Archer, R. P. (2010). A critical review of objective personality inventories with sex offenders. Journal of Clinical Psychology, 66, 1-27. https://doi.org/10.1002/jclp.20722

DeFauw, J., Ledsam, J. R., \& Ronneberger, O. (2018). Clinically applicable deep learning for diagnosis and referral in retinal disease, Nature Medicine, 24, 1342-1350. https://www.nature.com/articles/s41591-018-0107-6

Dillon, R. F., Pohlmann, J. T., \& Lohman, D. F. (1981) A factor analysis of Raven's Advanced Progressive Matrices freed of difficulty factors. Educational and Psycho logical Measurement, 41, 1295-1302. http://psycnet.apa.org/record/1982-11074-001

Dragisic, T., Dickov, A., Dickov, V., \& Mijatovic, V. (2015). Drug addiction as risk for suicide attempts. Materia Sociomedica, 27(3), 188-191. https://doi.org/:10.5455msm.2015.27.188-191

Dragisic, T., Jovanovic, M., Dickov, V., Bugarski, I., Ivetic, O., \& Miskovic, M. (2017). Heroin overdose- suicide or accident? Military Medical and Phamaceutical Review. https://doi.org/10.2298/VSP161212025D

Dresden, S. M., Powell, E. S., Kang, R., McHugh, M., Cooper, A. J., \& Feinglass, J. (2016). Increased emergency department use in Illinois after implementation of the Patient Protection and Affordable Care Act. Annals of Emergency Medicine, 69, 172-180. https://doi.org/10.1016/j.annemergmed.2016.06.026

Dunn, L. M., \& Dunn, L. M. (1977). Peabody Picture Vocabulary Test-III examiners manual. Circle Pines, MN: American Guidance Service.

Dunn, L. M., \& Dunn, L. M. (1997). Peabody Picture Vocabulary Test-III examiner's manual. Circle Pines, MN: American Guidance Service.

Duthie, B., \& McIvor, D. L. (1990). A new system for cluster-coding child molester MMPI profile types. Criminal 
Justice and Behavior, 17(2), 199-214. http://dx.doi.org/10.1177/0093854890017002004

Erickson, W. D., Luxenberg, M. G., Walbek, N. H., \& Seely, R. K. (1987). Frequency of MMPI two point code types among sex offenders. Journal of Consulting and Clinical Psychology, 55, 566-570. http://psycnet.apa.org/doi/10.1037/0022-006X.55.4.566

Faberow, N. L., \& Devries, A. G. (1967). An item differentiation analysis of MMPIs of suicidal neuropsychiatric hospital patients. Psychological Reports, 20, 607-617. https://doi.org/10.2466\%2Fpr0.1967.20.2.607

Federal Bureau of Investigation. (2012). Crime in the U.S.: Uniform crime reports. Washington, DC: U.S. Printing Office

Ferguson, D., Donnell, A., Slater, S., \& Fifield, J. (1975). The prediction of juvenile offending: A New Zealand study. Wellington, NZ: A. Shearer, Government Printer.

Fessenden, F. (2000). They threaten, seethe and unhinge, then kill in quantity. New York Times, 1.

Fields, G., \& Jones, C. (1999). Code of silence does not help. USA Today, June 1, A1-A2.

Flynn, J. R. (1984). The mean IQ of Americans: massive gains 1932-1978. Psychological Bulletin, 95, 29-51.

Flynn, J. R. (1987). Massive IQ gains in 14 nations: what IQ tests really measure? Psychological Bulletin, 101, 171-191.

Follman, M., Aronsen, G., \& Pan, D. (2012). A guide to mass shootings in America. Mother Jones. Retrieved from http://www.motherjones.com/politics/2012/07mass-shootings-map

Franklin, J. C., Ribeiro, J. D., Fox, K. R., Bentley, K. H., Kleiman, E. M., Huang, X., ... \& Nock, M. (2017). Risk factors for suicidal thoughts and behaviors: A meta-analysis of 50 years of research. Psychological Bulletin, 143, 187-232. http://dx.doi.org/10.1037/bul0000084

Friedman, A. F., Archer, R. P., \& Handel, R. W. (2005). Minnesota Multiphasic Personality Inventories (MMPI/MMPI-2, MMPI-A) and suicide. In R. I. Yufit \& D. Lester (Eds.) Assessment, treatment and prevention of suicidal behavior (pp.63-91). Hoboken, N.J.: Wiley.

Fry, F. D. (1949). A study of the personality traits of college students, and of state prison inmates as measured by the Minnesota Multiphasic Personality Inventory. Journal of Psychology: Interdisciplinary and Applied, 28, 439-449. http://psycnet.apa.org/doi/10.1080/00223980.1949.9916021

Fyfe, J. J., \& Kane, R. (2005). Bad cops: A study in career ending misconduct among New York City police officers. Washington, DC: National Institute of Justice.

Gartner, A. B., Graham, J. R., \& Archer, R. P. (1992). Usefulness of the MAC scale in differentiating adolescents in normal, psychiatric and substance abuse settings. Psychological Assessment, 4, 133-137. http://psycnet.apa.org/doi/10.1037/1040-3590.4.2.133

Geer, T. M., Becker, J. V., Gray, S. R., \& Krauss, D. (2001). Predictors of treatment completion in a correctional sex offender treatment program. International Journal of Offender Therapy and Comparative Criminology, 45, 302-313. https://doi.org/10.1177\%2F0306624X01453003

Gillin, J. L. (1943). Prediction of parole success in Wisconsin. Journal of Criminal Law and Criminology, 34, 236-239.

Given, J. B. (1977) Society and homicide in thirteenth-century England. Stanford, CA: Stanford University Press.

Glaser, D. (1962). Prediction tables as accounting devices for judges and parole decision boards. Crime and Delinquency, 8, 239-258.

Glassmire, D., Stolberg, R., Greene, R. L., \& Bongar, B. (2001). The utility of the MMPI-2 suicide items for assessing suicide potential: Development of a suicide potential scale. Assessment, 8, 281-290. https://doi.org/10.1177/107318110100800304.

Glueck, S., \& Glueck, E. T. (1950). Unraveling juvenile delinquency. New York: Common-Wealth Fund.

Goldkamp, J., \& Gottfredson, M. (1985). Policy guidelines for bail: an experiment in court reform. Philadelphia, PA: Temple University Press.

Goldkamp, J., Gottfredson, D. M., \& Jones, P. (1988). The implementation and evaluation of bail/pretrial release guidelines in Maricopa County Superior Court, Dade County Superior Circuit Court and Boston Municipal Court. National Institute of Justice Report. Philadelphia, PA: Temple University Press.

Gottesman, I. I., \& Prescott, C. A. (1989). Abuses of the MacAndrew MMPI Alcoholism Scale: A critical review. 
Clinical Psychology Review, 9(2), 223-242. http://dx.doi.org/10.1016/0272-7358(89)90029-9

Gottfredson, D. M., Wilkins, L. T., \& Hoffman, P. B. (1978). Guidelines for parole and sentencing. Lexington, MA: Lexington Books.

Gottfredson, M., \& Gottfredson, D. M. (1988) Decision making in criminal justice: toward the rational exercise of discretion. New York: Plenum.

Graham, J. R. (2000). MMPI-2. Assessing personality and psychopathology (3 ${ }^{\text {rd }}$ Ed.). New York: NY: Oxford University Press.

Greenwood, P. (1982) Selective incapacitation. Santa Monica, CA: RAND.

Grover, B. L. (2011). The utility of MMP-2 scores with a correctional population and convicted sex offenders. Psychology, 2, 638-642. https://file.scirp.org/pdf/PSYCH20110600016_82790397.pdf

Guy, E., Platt, J. J., Zwerling, I., \& Bullock, S. (1985). Mental health status of prisoners in an urban jail. Criminal Justice and Behavior, 12, 29-53. http://psycnet.apa.org/doi/10.1177/0093854885012001004

Hakeem, M. (1945). Glueck method of parole prediction applied to 1,861 cases of burglars. Journal of Criminal Law, Criminology, and Police Science, 36, 87-97.

Hakeem, M. (1948). The validity of the Burgess method of parole prediction. American Journal of Sociology, 53, 376-386.

Hall, G. C. N. (1989). WAIS-R and MMPI profiles of men who have sexually assaulted children. Journal of Personality Assessment, 53, 404-412. http://psycnet.apa.org/doi/10.1207/s15327752jpa5302_16

Hall, G. C. N., Graham, J. R., \& Shepherd, J. B. (1991). Three methods of developing MMPI taxonomies of sexual offenders. Journal of Personality Assessment, 56, 2-13. http://psycnet.apa.org/doi/10.1207/s15327752jpa5601_1

Hall, G. C. N., Maiuro, R. D., Vitaliano, P. P., \& Proctor, W. C. (1986). The utility of the MMPI with men who have sexually assaulted children. Journal of Consulting and Clinical Psychology, 54(4), 493-496. https://dx.doi.org/10.1037/0022-006X.54.4.493

Hanson, R. K., \& Thornton, D. (2000). Improving risk assessment for sex offenders: Comparison of 3 actuarial scales. Law and Human Behavior, 24, 119-136. http://dx.doi.org/10.1023/A:1005482921333

Harris, G. T., Rice, M. E., \& Quinsey, V. L. (1993). Violent recidivism of mentally disordered offenders: the development of a statistical prediction instrument. Criminal Justice and Behavior, 20, 315-335. http://psycnet.apa.org/doi/10.1177/0093854893020004001

Heersink, N., \& Strassburg, D. (1995). A normative and descriptive study of the MMPI with acknowledged child molesters. Journal of Psychopathology and Behavioral Assessment, 17, 377-391. http://dx.doi.org/10.1007/BF02229057

Hempel, A. G., Meloy, J. R., \& Richards, T. C. (1999). Offender and offense characteristics of a nonrandom sample of mass murderers. Journal of American Academy of Psychiatry and the Law, 27, 213-225.

Hoffman, P. B. (1983). Screening for risk: a revised salient factor score. Journal of Criminal Justice, 11, 539-547. http://psycnet.apa.org/doi/10.1016/0047-2352(83)90006-5

Hoffman, P. B., \& Beck, J. L. (1974). Parole decision-making: a salient factor score. Journal of Criminal Justice, 2, 195-206.

Hoffman, P. B., \& Beck, J. L. (1976). Salient factor score validation-a 1972 release cohort. Journal of Criminal Justice, 4, 69-76. https://www.ncjrs.gov/App/Publications/abstract.aspx?ID=37092

Hoffman, P. B., \& Beck, J. L. (1980). Revalidating the salient factor score: a research note. Journal of Criminal Justice, 8, 185-188. https://doi.org/10.1016/0047-2352(80)90025-2

Hoffman, P. B., \& Beck, J. L. (1985). Recidivism among released federal prisoners: salient factor score and five-year $\begin{array}{lllll}\text { follow-up. Criminal } \quad \text { Justice } & \text { Behavior, } & \text { 501-507. }\end{array}$ http://psycnet.apa.org/doi/10.1177/0093854885012004007

Holcomb, W. R., \& Anderson, W. P. (1983). Alcohol and Multiple Drug Abuse in Accused Murderers. Psychological Reports, 52, 159-164. https://doi.org/10.2466/pr0.1983.52.1.159

Holcomb, W. R., Adams, N. A., \& Ponder, H. M. (1985). The development and cross-validation of an MMPI typology of murderers. Journal of Personality Assessment, 49, 240-244. http://dx.doi.org/10.1207/s15327752jpa4903_4

Holcomb, W. R., Adams, N. A., Ponder, H. M., \& Anderson, W. P. (1984). Cognitive and behavioral predictors of 
MMPI scores in pretrial psychological evaluations of murderers. Journal of Clinical Psychology, 40, $592-597$.

Holland, T. R., Holt, N., \& Beckett, G. E. (1982). Prediction of violent versus nonviolent recidivism from prior violent and nonviolent criminality. Journal of Abnormal Psychology, 91, 178-218. http://psycnet.apa.org/doi/10.1037/0021-843X.91.3.178

Hsieh, M., Gutman, M., \& Haliscak, D. (2000). Clinical clearance of cervical spinal injuries by emergency nurses. Academic Emergency Medicine, 7, 342-347. https://www.ncbi.nlm.nih.gov/pubmed/10805621

Ingram, J. C., Marchioni, P., Hill, G., Caraveo-Ramos, E., \& McNeil, B. (1985) Recidivism, perceived problem-solving abilities, MMPI characteristics and violence: a study of black and white incarcerated male adult offenders. Journal of Clinical Psychology, 425-432. http://psycnet.apa.org/doi/10.1002/1097-4679(198505)41:3\%3C425::AID-JCLP2270410321\%3E3.0.CO;2-O

Jacobson, J., \& Wirt, R. D. (1969). MMPI profiles associated with outcomes of group therapy with prisoners. In J.N. Butcher (Ed.) Recent developments in the use of the MMPI (pp.191-206) New York: McGraw-Hill.

Jenkins, R. L., Hart, H. H., Sperling, P. I., \& Axelrod, S. (1942) Prediction of parole success: inclusion of psychiatric criteria. Journal of Criminal Law, Criminology, and Police Science, 33, 38-46.

Johnson, W., Bongar, B., \& Norland, M. (1999). The suicide patient: Clinical and legal standards of care. Washington, D.C.: American Psychological Association.

Johnson, W., Lall, R., Bongar, B., \& Norland, M. (1979). The role of objective personality inventories in suicide risk assessment: an evaluation and proposal. Suicide and Life Threatening Behavior, 29, 165-185. https://doi.org/101111/j.1943-278X,1999.tb01054.X.

Jones, L. H. (2013). Patriots release Aaron Hernandez take salary-cap hit. USA Today Sport.

Jones, P. (1991). The risk of recidivism: Evaluating the public safety implications of a community corrections program. Journal of Criminal Justice, 19, 49-66. https://doi.org/10.1016/0047-2352(91)90082-7

Jones, P., \& Goldkamp, J. (1991). The bail guidelines experiment in Dade County, Miami: a case study in the development and implementation of a policy innovation. Justice System Journal, 15, 445-476. https://doi.org/10.1111/j.1468-2311.1991.tb00703.x

Jones, T., Beidleman, W. B., \& Fowler, R. D. (1981). Differentiating violent and nonviolent prison inmates by use of selected MMPI scales. Journal of Clinical Psychology, 37, 673-678. http://psycnet.apa.org/doi/10.1002/1097-4679(198107)37:3\%3C673::AID-JCLP2270370340\%3E3.0.CO;2-P

Kalichman, S. C. (1988a). Empirically derived MMPI profile subgroups of incarcerated homicide offenders, Journal of Clinical Psychology, 43 4, https://doi.org/10.1002/1097-4679(198811)44:6\%3C847::AID-JCLP2270440603\%3E3.0.CO;2-\#

Kalichman, S. C. (1988b) MMPI profiles of women and men convicted of domestic homicide. Journal of Clinical Psychology,

44 , 846-855. https://doi.org/10.1002/1097-4679(198811)44:6<847::AID-JCLP2270440603>3.0.CO;2-\#

Kalichman, S. C. (1990). Affective and personality characteristics of MMPI profile subgroups of incarcerated rapists. Archives of Sexual Behavior, 20, 187-197. http://psycnet.apa.org/doi/10.1007/BF02442347

Kalichman, S. C. (1991). Psychopathology and personality characteristics of criminal sexual offenders as a function of victim age. Archives of Sexual Behavior, 20, 187-197. https://link.springer.com/article/10.1007/BF01541943

Kalichman, S. C., \& Henderson, M. C. (1991). MMPI profile subtypes of non-incarcerated child molesters. Criminal Justice and Behavior, 18, 379-396. https://doi.org/10.1177\%2F0093854891018004001

Kalichman, S. C., Craig, M. E., Shealy, L., Taylor, J., Szymanowski, D., \& McKee, G. (2008). An empirically derived typology of adult rapists based on the MMPI: A cross-validation study. Journal of Psychology and Human Sexuality, 2, 165-182. http://psycnet.apa.org/doi/10.1300/J056v02n02_11

Kalichman, S. C., Dwyer, M., Henderson, M. C., \& Hoffman, L. (1992). Psychological and sexual functioning among outpatient sexual offenders against children: A Minnesota Multiphasic Personality Inventory (MMPI) cluster analytic study. Journal of Psychopathology and Behavioral Assessment, 14, 259-276. https://link.springer.com/article/10.1007/BF00962632

Kalichman, S. C., Shealy, L., \& Craig, M. E. (1990). The Use of the MMPI in predicting treatment participation among incarcerated adult rapists, Journal of Psychology and Human Sexuality, 3, 105-119. https://doi.org/10.1300/J056v03n02_08 
Kalichman, S. C., Szymanowski, D., McKee, G., Taylor, J., \& Craig, M. E. (1989). Cluster analytically derived MMPI profile subgroups of incarcerated adult rapists. Journal of Clinical Psychology, 45, 149-155. http://psycnet.apa.org/doi/10.1002/1097-4679(198901)45:1\%3C149::AID-JCLP2270450123\%3E3.0.CO;2-1

Kandel, E., Brennan, P. A., Mednick, S. A., \& Mickelson, N. M. (1989). Minor physical anomalies and recidivistic adult violent criminal behavior. Acta Psychiatrica Scandinavica, 79, 103-107.

Kang, H. K., Natelson, B. H., Mahan, C. M., Lee, K. Y., \& Murphy, F. M. (2003). Post-traumatic stress disorder and chronic fatigue syndrome among Gulf War veterans: A population based study of 30,000 veterans. American Journal of Epidemiology, 157, 141-148. http://dx.doi.org/10.1093/aje/kwf187

Kassenbaum, G., Davidson-Coronado, J., Perrone, P., \& Allen, J. (2001). Parole decision making in Hawaii. Honolulu, HI: Research and Statistics Branch Crime Prevention and Justice Assistance Division, Department of Attorney General.

Kessler, R. C., Heeringa, S. G., Stein, M. B., Colpe, L. J., Fullerton, C. S., \& Ursano, R. J. (2014). 30 prevalence of DSM-IV mental disorders among non-deployed soldiers in the U.S. Army: Results from the Army Study to Assess Risk and Resilience in Service members (Army STARRS). Journal of the American Medical Association, Psychiatry, 71, 514-522. https://doi.org/10.1001/jamapsychiatry.2014.28

KFF [Henry Kaiser Family Foundation] (2018). Employer health benefits survey. Retrieved from: https://www.kff.org/health-costs/report/2018-employer-health-benefits-survey/

Kirk, K. (1982). Experimental design. New York: Brooks-Cole.

Klassen, D., \& O'Connor, W. A. (1988). Predicting violence in schizophrenic and non- schizophrenic patients: a prospective study. Journal of Clinical Child and Adolescent Psychology, 1, 75-81. http://psycnet.apa.org/doi/10.1037/1040-3590.1.2.75

Langevin, R., Wright, P., \& Handy, L. (1990). Use of the MMPI and its derived scales with sex offenders: I. Reliability and validity studies, Annals of Sex Research, 3, 245-291. http://psycnet.apa.org/doi/10.1037/0022-006X.52.5.841

Lanyon, R. I. (1993). Validity of MMPI sex offender scales with admitters and no admitters. Psychological Assessment, 5, 302-306. http://psycnet.apa.org/doi/10.1037/1040-3590.5.3.302

Lanyon, R. I., \& Lutz, R. W. (1984). MMPI discrimination of defensive and non-defensive felony sex offenders. $\begin{array}{lllll}\text { Journal of Clinical and } & \text { Consulting }\end{array}$ http://psycnet.apa.org/doi/10.1037/0022-006X.52.5.841

Lawton, M. P., \& Kleban, M. H. (1965). Prisoners' faking on the MMPI. Journal of Clinical Psychology, 21, 269-271. http://psycnet.apa.org/doi/10.1037/0022-006X.52.5.841

Leonard, C. V. (1974). Depression and suicidality. Journal of Consulting and Clinical Psychology, 42, 98-104. http://psycnet.apa.org/doi/10.1037/h0036048

Leonard, C. V. (1977). The MMPI as a suicide predictor. Journal of Consulting and Clinical Psychology, 45, 367-377.

Lester, D. (1971). MMPI scores of old and young completed suicides. Psychological Reports, 28, 146. http://psycnet.apa.org/doi/10.2466/pr0.1971.28.1.146

Levin, S. M., \& Stava, L. (1987). Personality characteristics of sex offenders: A review. Archives of Sexual Behavior, 16, 57-77. https://www.ncbi.nlm.nih.gov/pubmed/3579558

Lidz, C. (1993). The accuracy of predictions of violence to others. Journal of the American Medical Association, 269, 1007-1009. https://www.ncbi.nlm.nih.gov/pubmed/8429581

Loke, S. S., Liaw, S. J., Tiong, L. K., Ling, T. S., \& Chang, W. T. (2002). Evaluation of nurse-physician inter-observer agreement on triage categorization in the emergency department of a Taiwan Medical Center. Chang Gung Medical Journal, 25, 446-452. http://europepmc.org/abstract/med/12350030

Looney, T. F. (2007). MMPI-2 profile comparison of intrafamilial and extrafamilial sex offenders against children. Unpublished master's thesis. Pacific University. Retrieved from: http://commons.pacificu.edu/ssp/18

Losada-Paisley, G. (1998). Use of the MMPI-A to assess personality of male delinquents who are sex offenders and non-sex offenders. Psychological Reports, 83, 115-122.

Madan, S. S., \& Harley, J. M. (2003). Inter-observer error in interpretation of the radiographs for degeneration of the lumbar spine. Iowa Orthopedic Journal, 23, 51-56. https://www.ncbi.nlm.nih.gov/pmc/articles/PMC1888399/ 
Mannheim, H., \& Wilkins, L. (1955). Prediction methods in relation to Borstal training. London, UK: Her Majesty's Stationery Office.

McClintock, F. H. (1961). Attendance centers: an enquiry by the Cambridge Institute of Criminology on the issue of Section 19 of the Criminal Justice Act 1948. New York: Macmillan.

McCreary, C. P. (1975). Personality differences among child molesters. Journal of Personality Assessment, 39 , 591-593. https://doi.org/10.1207/s15327752jpa3906_7

McKee, G. R., Shea, S. J., Mogy, R. B., \& Holden, C. E. (2001). MMPI-2 profiles of filicidal, matricidal, and homicidal women, Journal of Clinical Psychology, 57(3), 367-374. https://www.ncbi.nlm.nih.gov/pubmed/11241366

Mednick, M. T. (1969). The validity of the Ammons' Quick Test of Intelligence. Psychological Reports, 24(2), 388-390. http://dx.doi.org/10.2466/pr0.1969.24.2.388

Megargee, E. I. (2006). Using the MMPI-2 in criminal justice and correctional settings. Minneapolis, MN: University of Minnesota Press.

Megargee, E. I. (2008). Understanding and assessing aggression and violence. In J. N. Butcher, J. Perry, \& B. L. Dean (Eds.), Oxford handbook of clinical and personality assessment. New York: Oxford University. Press.

Megargee, E. I. (Ed.) (1977). A new classification system for criminal offenders [Special issue]. Criminal Justice and Behavior, 4(2).

Megargee, E. I., \& Bohn, M. J. (1977). IV: Empirically determined characteristics of the ten types. Criminal Justice and Behavior, 4, 149-210.

Megargee, E. I., Carbonell, J. L., Bohn, M. J., \& Sliger, G. L. (2001). Classifying criminal offenders with the MMPI-2: The Mecgargee system. Minneapolis, MN: University of Minnesota Press.

Metzner, R., \& Weil, G. (1963). Predicting recidivism: base rates for Massachusetts Correctional Institution. Journal of Criminal Law, Criminology, and Police Science, 54, 307-316. https://scholarlycommons.law.northwestern.edu/cgi/viewcontent.cgi?referer=https://www.google.com/\&httpsredi $\mathrm{r}=1 \&$ article $=5174 \&$ context $=\mathrm{jclc}$

Micucci, J. A. (2003). Accuracy of MMPI-A scales ACK, MAC-R, and PRO in detecting comorbid substance abuse among psychiatric inpatients. Assessment, 9, 111-122. https://doi.org/10.1177/10791102009002001

Miller, T. R. (1997). Societal costs of transportation crashes. In D. Greene, D. Jones, \&. M. Delucchi (Eds.), The full society cost and benefits of transportation (pp. 327-342). Heidelberg, Germany: Springer-Verlag. http://dx.doi.org/10.1007/978-3-642-59064-1_10

Miller, T. R., Cohen, M. A., \& Wiersema, B. (1996). Victim costs and consequences: a new look. National Institute of Justice Research Report (NCJ-155282, Feb.) Washington, DC: U.S. Department of Justice.

Miner, M. H., Marques, J. K., Day, D. M., \& Nelson, C. (1990). Impact of relapse prevention in treating sex offenders: Preliminary findings. Annals of Sex Research, 3, 165-185. https://doi:10.1007/BF00850869

Monachesi, E. D. (1932). Prediction factors in probation. Hanover, NH: The Sociological Press.

Monahan, J. (1981). Predicting violent behavior: an assessment of clinical techniques. Beverly Hills, CA: Sage.

Monahan, J. (1996). Violence prediction. Criminal Justice and Behavior, 23, 107-120.

Monahan, J. (2006). A jurisprudence of risk assessment: forecasting harm among prisoners, predators, and patients. Virginia Law Review, 92, 391-435.

Monahan, J. Steadman, H. J., Appelbaum, P. S., Robbins, P. C., Mulvey, E. P., Silver, E., ... \& Grisso, T. (2000). Developing a clinically useful actuarial tool for assessing risk. British Journal of Psychiatry, 176, 312-319.

Moosman, D. (2013). When forensic examiners disagree: Bias or just inaccuracy? Psychology, Public Policy and the Law, 19, 40-45.

National Center for Missing and Exploited Children (2017). Registered sex offenders in the United States and its territories per 100,000 population. https://api.missingkids.org/en_US/documents/Sex_Offenders_Map.pdf

National Center for Statistics and Analysis Advanced Research and Analysis (2003). Analysis of large truck crashes. Washington, D.C.: U. S. Printing Office. Retrieved from http://www-nrd.nhtsa.dot.gov/Pubs/809-569.pdf

National Law Enforcement Officers Memorial Fund. (2015). Officer deaths by year throughout U.S. history. Washington, D.C... Retrieved from http://www.nleomf.org/facts/officer-fatalities-data/year.html 
Nock, M. K., Stein, M. B., Heeringa, S. G., Ursano, R. J., Colpe, L. J., Fullerton, C. S., \& Kessler, R. C. (2014). Prevalence and correlates of suicide behavior among soldiers: Results from the Army Study to Assess Risk and Resilience in Service members (Army STARRS). Journal of the American Medical Association, Psychiatry, 71, 514-522. http://dx.doi.org/10.1001/jamapsychiatry.2014.30

Nuffield, J. (1982). Parole decision making in Canada: research towards decision guidelines. Communication Division, Solicitor General Canada, Minister of Supply and Services Canada, Ottawa, Ontario.

O'Connor, S. A. (1990). Personality characteristics of sex offenders: A comparison of the MMPI and MCMI. Unpublished master's thesis. Simon Fraser University Psychology Department, November. Retrieved from: https://pdfs.semanticscholar.org/146a/aff08c15796f4b25f628048627c1425d2b4e.pdf

Occupational Therapists (2018). Occupational therapists in the U.S. Occupational Outlook Handbook U.S. Bureau of Labor Statistics, Washington, D.C.: U.S. Printing Office. Retrieved from: https://www.bls.gov/ooh/healthcare/occupational-therapists.htm

Ohlin, L. E. (1951). Selection for parole: a manual of parole prediction. New York: Russell Sage Found.

Ohlin, L. E., \& Duncan, O. D. (1949). The efficiency of prediction in criminology. American Journal of Sociology, 54, 441-451.

Oliver, M. E., Coupland, R. B. A., \& Kurtenbach, T. J. A (2018). Risk need responsivity applications of the MMPI-2 in sexual offender assessment. Psychology, Crime and Law, 24, 1. http://dx.doi.org/10.1080/1068316X.2018.1`438434.

Olson, D. E., \& Taheri, S. (2012). Population dynamics and the characteristics of inmates in Cook County Jail. Criminal Justice and Criminology: Faculty Publications and Other Works. February, Loyola University of Chicago, Loyola e Commons. https://ecommons.luc.edu/cgi/viewcontent.cgi?article=1000\&context=criminaljustice_facpubs

One Summer Chicago (2018). One Summer Chicago Program. Retrieved from: http://www.onesummerchicago.org/faq/

Pallis, D. J., \& Birtchnell, J. (1977). Seriousness of suicide attempt in relation to personality. British Journal of Psychiatry, 130, 253-259. http://psycnet.apa.org/doi/10.1192/bjp.130.3.253

Panton, J. H. (1976). Personality characteristics of death-row prison inmates. Journal of Clinical Psychology, 32, 306-309.

http://psycnet.apa.org/doi/10.1002/1097-4679(197604)32:2\%3C306::AID-JCLP2270320224\%3E3.0.CO;2-M

Panton, J. H. (1978). Personality differences appearing between rapists of adults, rapists of children and non-violent sexual molesters of female children. Research Communications in Psychology, Psychiatry and Behavior, 3, 385-393. http://psycnet.apa.org/record/1980-21289-001

Pavelka, F. L. (1986). Psychosocial characteristics of parolees in forensic social work. Journal of Psychiatry and Law, 14, 217-223. http://psycnet.apa.org/record/1988-10959-001

Persons, R. W., \& Marks, P. A. (1971). The violent 4-3 MMPI personality type. Journal of Clinical Psychology, 36 (2), 189-196. http://psycnet.apa.org/doi/10.1037/h0030742

Physical Therapists (2018). Physical therapists in the U.S. Occupational Outlook Handbook U.S. Bureau of Labor Statistics, Washington, D.C.: U.S. Printing Office. Retrieved from: https://www.bls.gov/ooh/healthcare/physical-therapists.htm

Pietarieu, H. (1986). Item analysis and standardization of Raven's Advanced Progressive Matrices. Revisita Psihologie, 32, 33-43.

Pietrulewicz, B. (2006). Personality profiles for sexual abusers based on the MMPI-2. Polskie Forum Psychologiczne, $\begin{array}{lllll}\text { (Polish Psychological } & \text { Forum) 11, 173-178. }\end{array}$ https://repozytorium.ukw.edu.pl/bitstream/handle/item/906/Bogdan\%20Pietrulewicz\%20Personality\%20Profiles $\%$ 20for\%20Sexual\%20Abusers\%20Based\%20on\%20the\%20MMPI-2.pdf?sequence=1\&isAllowed=y

Poeldinger, W. P., Gehring, A., \& Blaser, P. (1973). Suicide risk and MMPI scores, especially as related to anxiety and depression. Suicide and Life Threatening Behavior, 3, 147-153. https://doi.org/10.1111/j.1943-278X.1973.tb00981.x

Polimeni, A. M., Moore, S. M., \& Gruenert, S. (2010). MMPI-2 profile of clients with substance dependencies accessing a therapeutic community treatment facility. Drug and Alcohol Review, 29, 546-550. 
https://doi.org/10.1111/j.1465-3362.2010.00175.x.

Pompili, M., Innamorati, M., Di Vittorio, C., Baratta, S., Masotti, V., Badaracco, A., ... \& Amore, M. (2014). Unemployment as a risk factor for completed suicide: a psychological autopsy study. Archives of Suicide Research, 18, 181-192. https://doi.org/10.1080/13811118.2013.8034

Pompili, M., Rihmer, Z., Akiskal, H. S., Innamorati, M., Iliceto, P., Akiskal, K. K., ... \& Girardi, P. (2008). Temperament and Personality Dimensions in Suicidal and Nonsuicidal Psychiatric Inpatients: 322 First-Episode Psychosis: Diagnostic St Psychopathology, 48, 313-321. Retrieved from: https://www.karger.com/Article/Pdf/164986

Pope, K. S., Butcher, J. N., \& Seelen, J. (2006) MMPI, MMPI-2, MMPI-A in court: a practical guide for expert witnesses and attorneys. (3rd ed.) Washington, DC: American Psychological Association.

Quinsey, V. L., Arnold, L. S., \& Pruesse, M. G. (1980). MMPI profiles of men referred for a pretrial psychiatric assessment as a function of offense type. Journal of Clinical Psychology, 36, 410-417. http://psycnet.apa.org/doi/10.1002/jclp.6120360204

Quinsey, V. L., Harris, G. T., Rice, M. E., \& Cormier, C. A. (1998). Violent offenders: appraising and managing risk. Washington, DC: American Psychological Association.

Quinsey, V. L., Harris, G. T., Rice, M. E., \& Cormier, C. A. (2006). Violent offenders: appraising and managing risk. $\left(2^{\text {nd }}\right.$ ed.) Washington, DC: American Psychological Association.

Quinsey, V. L., Harris, G. T., Rice, M. E., \& Cormier, C. A. (2015). Violent offenders: appraising and managing risk. $\left(3^{\text {rd }}\right.$ ed.) Washington, DC: American Psychological Association.

Quinsey, V. L., Pruesse, M., \& Fernley, R. (1975). Oak Ridge patients: prerelease characteristics and post-release adjustment. Journal of Psychiatry and Law, 3, 63-77.

Rader, C. M. (1977). MMPI profile types of exposers, rapists, and assaulters in a court services population. Journal of Consulting and Clinical Psychology, 45, 61-69. http://psycnet.apa.org/doi/10.1037/0022-006X.45.1.61

Rautji, R., \& Dogram, T. T. (2004). Rail traffic accidents: A retrospective study. Medical Science and the Law, 44: 67-70.

Raven, J. (1965). Advanced Progressive Matrices. London, UK: Grieve Printers.

Raven, J. (1990). Raven Manual Research Supplement 3. American and international norms-neuropsychological uses. New York: Oxford Psychologists Press.

Ravensborg, M., \& Foss, A. (1969). Suicide and natural death in a state hospital population: A comparison of admission complaints, MMPI profiles, and social competence factors. Journal of Consulting and Clinical Psychology, 33, 466-471. http://psycnet.apa.org/record/1969-16032-001

Redden, E. (1939). Embezzlement: a study of one kind of criminal behavior with prediction tables based on fidelity insurance records. Unpublished doctoral dissertation. University of Chicago, Chicago, Illinois.

Rice, M. E., \& Harris, G. T. (1997). Cross-validation and extension of the Violence Risk Appraisal Guide for child molesters and rapists. Law and Human Behavior, 21, 231- 241. http://psycnet.apa.org/doi/10.1023/A:1024882430242

Rice, M. E., Harris, G. T., \& Quinsey, V. L. (1996). Predicting the Recidivism of Mentally Disordered Fire setters. Journal of Interpersonal Violence, 11, 351-363. https://doi.org/10.1177\%2F088626096011003004

Rishe, P. (2013). Despite being cut, Aaron Hernandez will cost New England Patriots millions over next two seasons, Business. Retrieved from http://www.forbes.com/sites/prishe/2013/06/26/the-release-of-aaron-hernandez-reduces-new-enlgand-patriots-sal ary-cap.

Romeo, L., Balducci, C., Quintarelli, E., Riolfi A., Pelizza L., Serpelloni, A., .. \& Perbellini, L. (2013). MMPI-2 personality profiles and suicide ideation and behavior in victims of bullying at work: A follow-up study. Violence and Victims, 28, 1000-1014. https://www.ncbi.nlm.nih.gov/pubmed/24547677

Romo, J. D. (2009). An examination of the classification types and MMPI-2 characteristics of organized and disorganized murderers. FBI Law Enforcement Bulletin, 54, 18-25.

Rosen, E., \& Mink, S. H. (1961). Desirability of personality traits as perceived by prisoners. Journal of Clinical Psychology, 
Ruhl, J., \& Ruhl, D. (2016). National Catholic Reporter research: Costs of sex abuse crisis to U.S. church underestimated. National Catholic Reporter, 52, 1-16.

Schneider, M., \& Palcski, N. (2018). Personal injury attorneys. Retrieved from: https://www.northcountrylaw.com/

Schoenbaum, M., Kessler, R. C., Gilman, S. E., Colpe, L. J., Heeringa, S. G., Stein, M. B., \& Cox, K. L. (2014). Predictors of suicide and accidental death in the Army Study to Assess Risk and Resilience in service members in the Army (Army STARRS). Journal of the American Medical Association, Psychiatry, 71, 493-503.

Schroeder, A. (2016). Millions in misconduct. Chicago Sun Times, 31(24).

Schultz, N. R., Kaye, D. B., \& Hoyer, W. J. (1980). Intelligence and spontaneous flexibility in adulthood and old age. Intelligence, 4, 219-231. http://psycnet.apa.org/doi/10.1016/0160-2896(80)90020-3

Sendbuehler, J. M., Kincel, D. D., Nemeth, G., \& Oertel, J. (1979). Dimensions of seriousness attempted suicide: Significance of the Mf scale in suicidal MMPI profiles. Psychological Reports, 44, 343-361. http://psycnet.apa.org/doi/10.2466/pr0.1979.44.2.343

Sepaher, I., Bongar, B., \& Greene, R. L. (1999). Code type base rates for the "I mean business" suicide items of the MMPI-2. Journal of Clinical Psychology, $1167-1173$. http://psycnet.apa.org/doi/10.1002/(SICI)1097-4679(199909)55:9\%3C1167::AID-JCLP13\%3E3.0.CO;2-6

Sepejak, D. S., Menzies, R. J., Webster, C. D., \& Jensen, F. A. C. (1983). Clinical predictions of dangerousness: two-year follow-up of 408 pretrial forensic cases. Bulletin of the American Academy of Psychiatry and the Law, 11, 171-180. Retrieved from https://www.researchgate.net/publication/16580401_Clinical_predictions_of_dangerousness_Two-year_follow-up _of_408_pre-trial_forensic_cases

Shea, S. J., \& McKee, G. R. (1996). MMPI-2 profiles of men charged with murder or other offenses. Psychological Reports, 78, 1039-1042. http://psycnet.apa.org/doi/10.1016/0160-2527(95)00008-6

Shealy, L., Kalichman, S. C., Henderson, M. C., Szymanowski, D., \& McKee, G. (1991). MMPI profile subtypes of incarcerated sex offenders against children. Violence and Victims, 6, 201-212. https://www.ncbi.nlm.nih.gov/pubmed/1818618

Siegel, D. (2015). Human error is unforgivable when we shun infallible algorithms. Financial Times, 7.

Simon, F. (1956). Prediction methods in criminology. London, UK: Her Majesty's Stationery Office.

Simon, W., \& Gilberstadt, H. (1958). Analysis of the personality structure of 26 actual suicides. Journal of Nervous and Mental Disease, 127, 555-557. http://psycnet.apa.org/doiLanding?doi=10.1037\%2Fh0027822

Smith, R. E. (1955). Personality configurations of adult male penal populations as revealed by the MMPI. Doctoral dissertation, University of Minnesota (DA, 16, 160.

Soothill, K. L., Way, G. K., \& Gibbens, T. C. N. (1980). Compulsory hospital patients. British Journal of Criminology, 20, 289-295.

Spans, M., Barendregt, M., Muller, E., de Beurs, E., Nijman, H. \& Rinne, T. (2009). MMPI profiles of males accused of severe crimes: A cluster analysis. Psychology Crime and Law, 15, 441-450. https://doi.org/10.1080/10683160802356704

Speder, Z. (2005). Diversity of family structure in Europe. Paper presented at the 25th conference of the International Union for the Scientific Study of Population, Tours, France, July 21.

Speech Therapists. (2018). Speech therapists in the U.S. Occupational Outlook Handbook U.S. Bureau of Labor Statistics, Washington, D.C.: U.S. Printing Office. Retrieved from: https://www.bls.gov/ooh/healthcare/speech-therapists.htm

Spirito, A., Faust, D., Myers, B., \& Bechtel, D. (1988). Clinical utility of the MMPI in evaluation of adolescent suicidal attempters. Journal of Personality Assessment, 52, 201-211.

Stander, V. A., Merrill, L. L., Thomsen, C. J., Crouch, J. L., \& Milner, J. S. (2008). Premilitary adult sexual assault victimization and perpetration in a Navy recruit sample. Journal of Interpersonal Violence, 23, $1636-1653$. http://dx.doi.org/10.1177/0886260508314325

Statista. (2018). All the facts you need in one place. Retrieved from: https://www.statista.com/

Steadman, H. J. (1983). Predicting dangerousness among the mentally ill: art, magic, and science. International Journal of Law and Psychiatry, 6, 381-390. http://psycnet.apa.org/doi/10.1016/0160-2527(83)90025-0 
Stein, L. A. R., \& Graham, J. R. (2005). Ability of substance abusers to escape detection on the Minnesota Multiphasic Personality Inventory Adolescent (MMPI-A) in a juvenile correctional facility. Assessment, 12(1) 28-39. https://dx.doi.org/10.1177\%2F1073191104270838

Stein, L. A. R., Graham, J. R., Ben-Porath, Y. S., \& McNulty, J. L. (1999). Using the MMPI-2 to detect substance abuse in an outpatient mental health setting. Psychological Assessment, 11, 94-100. http://psycnet.apa.org/doi/10.1037/1040-3590.11.1.94

Sutker, P. P., Allain, A. N., \& Geyer, S. (1978). Female criminal violence and differential MMPI characteristics.

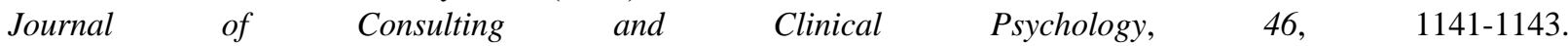
http://psycnet.apa.org/doi/10.1037/0022-006X.46.5.1141

Svanum, S., \& Ehrmann, L. (1992). Alcoholic subtypes and the MacAndrew Alcoholism Scale. Journal of Personality Assessment, 58, 411-422. https://doi.org/10.1207/s15327752jpa5802_17

Svanum, S., \& Ehrmann, L. (1993). The validity of the MMPI in identifying alcoholics in a university setting. Journal of Studies on Alcohol, 54, 722-729. http://psycnet.apa.org/doi/10.1207/s15327752jpa6002_15

Svanum, S., McGrew, J., \& Ehrmann, L. (1994). Validity of the substance abuse scales of the MMPI-2 in a college $\begin{array}{llllll}\text { student sample. Journal of Personality } & \text { Assessment, }\end{array}$ http://psycnet.apa.org/doi/10.1207/s15327752jpa6203_4weed

Tarter, R. E., Templer, D. I., \& Perley, R. L. (1975). Social role orientation and pathological factors in suicide attempts of varying lethality. Journal of Community Psychology, 3, 295-299.

Tibbits, C. (1931). Success or failure on parole can be predicted. Journal of Criminal Law and Criminology, 22, 11-50.

Titano, J. J., Badgeley, M., Schefflein, J., Pain, M., Su, A., Cai, M., ... \& Oermann, E. K. (2018) Automated deep-neural-network surveillance of cranial images for acute neurologic events, Nature Medicine, 24, 1337-1341 https://www.nature.com/articles/s41591-018-0147-y

Tomak, S., Wechsler, F. S., Ghahramanlou-Holloway, M., Virden, T., Nademin, M. E. (2009). An empirical study of the personality characteristics of internet sex offenders. Journal of Sexual Aggression, 15, 139-148. https://doi:10.1080/13552600902823063

Toy, S. (2018). U.S. roadway fatalities are still near 10- year high. Wall Street Journal, $16^{\text {th }}$ February A3

U.S. Attorney General. (1939). Survey of release procedures. Vol. 4: Parole. Washington, DC: U.S. Printing Office.

U.S. Bureau of Justice Statistics. (2014). Annual Statistics. Washington, D.C.: U.S. Printing Office.

U.S. Census Bureau. (2018). The 2018 Census Population counts, Washington, DC: U.S. Printing Office.

U.S. Conference of Catholic Bishops. (2014). 2013 Annual report finding and recommendations: March 2014 report on the implementation of charter for protection of children and young people. Washington, D.C. Retrieved from http://www.usccb.org/issues-and-action/child-and-youth-protection/upload/2013-Annual-Report.pdf

U.S. Department of Defense. (2007). Accession medical standards analysis research activity (AMSRA) (pp. 93-108). Washington, D.C.: U.S. Government Printing Office.

U.S. Department of Defense. (2008). Accession medical standards analysis research activity (AMSRA) (pp. 93-108). Washington, D.C.: U.S. Government Printing Office.

U.S. Department of Defense. (2009a). Accession medical standards analysis research activity (AMSRA) (pp. 93-108). Washington, D.C.: U.S. Government Printing Office.

U.S. Department of Defense. (2009b). Department of Defense personnel statistics. Retrieved from http://siadapp.dmdc.osd.mil

U.S. Department of Defense. (2009c). United States military basic training attrition rates. Retrieved from http://usmilitary.about.com/

U.S. Department of Health and Human Services Center for Disease Control and Prevention Center for Health Services. (2014). Health U.S. 2015. Rockville, MD: U.S. Government Printing Office. Retrieved from http://www.cdc.gov/nchs/data/hus/hus14

U.S. Department of Health and Human Services. (2009). National expenditures for mental health services and substance abuse treatment 1986-2009. Rockville, MD: U.S. Government Printing Office. Retrieved from http://www.cdc.gov/nchs/data/hus/hus09.pdf

U.S. Department of Justice, Bureau of Justice Statistics (1997). Sex offenses and offenders. An analysis of rape and 
sex offenders. Lawrence A. Greenfeld. February, NCJ-163392. Washington, D.C.: U.S. Printing Office. Retrieved from: https://bjs.gov/content/pub/pdf/SOO.PDF

U.S. Department of Transportation, National Highway Traffic Safety Administration. (2014). U.S. traffic safety facts: Large trucks. Retrieved from http://www-nrd.nhtsa.dot.gov/Pubs/811868.pdf

U.S. Department of Veterans Affairs Office of the Actuary. (2014). Veteran Population Projection Model. Washington, D.C.: U.S. Government Printing Office.

U.S. Department of Veterans Affairs Office of the Actuary. (2014). Estimated number of veteran suicides per day by year. Washington, D.C.: U.S. Government Printing Office.

U.S. Energy Information Administration. (2009). Nuclear energy review. Washington, D.C.:

U.S. Energy Information Administration. (2013). Oil and gas industry employment growing faster than the total private sector employment. Washington, D.C.: U.S. Printing Office. Retrieved from http://www.eia.gov/todayinenergy/detail.cfm?id=12451

U.S. Government Printing Office.

U.S. Navy. (1959). Parole decision-making. In F. H. McClintock (Ed.), Attendance centers: an enquiry by the Cambridge Institute of Criminology on the issue of Section 19 of the Criminal Justice Act of 1948. New York: Macmillan.

U.S. Nuclear Regulatory Commission. (2013). Summary of fitness for duty program performance for calendar year 2012. Retrieved from http://pbaqdupws.nrc.gov/docs/mL1322/

U.S. Nuclear Regulatory Commission. (2014). U.S. Nuclear Power Plant Fitness for Duty Reports: 2008-2013. Retrieved from http://www.fairewinds.org/nuclear-energy-education//fitness-for-duty-event-reports-2008-2 013

Van Vechten, C. C. (1933). A study of success and failure of 1,000 delinquents to a boy's republic. Unpublished doctoral dissertation, University of Chicago, Chicago, IL

Vikert, B., \& Zahnd, W. (1965). Parole: low and high risk parolees. Canadian Journal of Corrections, 7, 37-48.

Vold, G. B. (1930). Factors entering into success or failure of Minnesota men on parole. Publications of the American Sociological Society, 24, 167-169.

Vold, G. B. (1931). Prediction methods and parole. Hanover, NH: The Sociological Press.

Vold, G. B. (1935). Prediction methods applied to problems of classification within institutions. Journal of Criminal Law and Criminology, 26, 202-209.

Walker, N., \& McCabe, S. (1973). Crime and insanity in England. Vol. 2. Edinburgh, UK: University. of Edinburgh.

Walsh, C. G., Ribeiro, J. D., \& Franklin, J. C. (2017). Predicting Risk of Suicide Attempts Over Time Through Machine Learning. Clinical Psychological Science, 1-12. https://doi.org/10.1177\%2F2167702617691560

Walters, G. D. (1987). Child sex offenders and rapists in a military prison setting. International Journal of Offender Therapy and Comparative Criminology, 31, 261-269.

Ward, P. G. (1968). The comparative efficiency of different techniques in prediction scaling. Australian and New Zealand Journal of Criminology, 2, 109-112.

Warner, S. B. (1923) Factors determining parole from the Massachusetts Reformatory. Journal of Criminal Law and Criminology, 14, 172-207.

Wasyliw, O. E., Grossman, L. S., Haywood, T. W., \& Cavanaugh, J. L. (1988). The detection of malingering in criminal forensic groups: MMPI validity scales. Journal of Personality Assessment, 52(2), 321-333. http://psycnet.apa.org/doi/10.1207/s15327752jpa5202_13

Waters, B. G. H., Sendbuchler, J. M., Kineel, R. I., Boodousingh, L. A., \& Marchenko, I. (1982). The use of the MMPI for the differentiation of suicide and non-suicide depressions. Canadian Journal of Psychiatry, 27, 663-667.

Watkins, W. U. (2000). MMPI-2 profile configurations associated with convicted sex offenders from two West Virginia department of correction facilities. Dissertation Abstracts International: Section B: The Sciences \& Engineering, 60(11-B), 5798

Watson, C. Klett, W., Walters, C., \& Vassar, P. (1984). Suicide and the MMPI: A cross validation of predictors. $\begin{array}{lllll}\text { Journal of Clinical } & \text { Psychology, } & 40, & 115-119 .\end{array}$ Doi:10.1002/1097-4679(198401)40:1<115::AID-JCLP2270400120>3.0CO:2-N. 
Watson, C., Klett, W., Walters, C., \& Laughlin, P. (1983). Identification of suicide episodes with the MMPI. Psychological Reports, 53, 919-922. https://dx.doi.org.10.2466/pr0.1983.53.3.919.

Weed, N. C., Butcher, J. N., \& Williams, C. L. (1994). Development of MMPI-A alcohol/drug problem scales. Journal of Studies on Alcohol, 55, 296-302. http://dx.doi.org/10.15288/jsa.1994.55.296

Weed, N. C., Butcher, J. N., McKenna, T., \& Ben-Porath, Y. S. (1992). New measures for assessing alcohol and drug abuse with the MMPI-2: the APS and AAS. Journal of Personality Assessment, 58, 389-404. https://doi.org/10.1207/s15327752jpa5802_15

Weeks, H. A. (1943). Predicting juvenile delinquency. American Sociological Review, 8, 40- 46.

Weiss, A. J., Barrett, M. L., \& Steiner, C. A. (2014). Trends and projections in inpatient hospital costs and utilization, 2003-2013. Health Care Cost and Utilization Project Statistical Brief, 175, 1-7. https://www.hcup-us.ahrq.gov/reports/statbriefs/sb175-Hospital-Cost-Utilization-Projections-2013.jsp

Weiss, K. J., \& Farrell, J. M. (2006). PTSD in railroad drives under the federal employers' liability act. The Journal of the American Academy of Psychiatry and the Law, 34, 191-199. http://psycnet.apa.org/record/2006-09510-009

Welch, W. M., \& Hoyer, M. (2013). Thirty mass killings, 137 victims: A typical year. USA Today, 1A, 5A.

Wenk, E., Robinson, J., \& Smith, G. (1972). Can violence be predicted? Crime and Delinquency, 18, 393-402.

Wilcox, D. E. (1985). The relationship of mental illness to homicide. American Journal of Forensic Psychiatry, 6, 3-15. http://psycnet.apa.org/record/1985-22791-001

Wilhelm, A. (2010). The long scandal: A history of abuse. Huffington Post.

Wilson, S. C. (1994). MMPI-2 profile differences among sex offender groups. Unpublished master's thesis, Emporia State University. Retrieved from: http://hdl.handle.net/123456789/1721)

Wolfson, K. P, Erbaugh, S. E. (1984). Adolescent responses to the MacAndrew Alcoholism Scale. Journal of Consulting and Clinical Psychology, 52, 625-630. http://psycnet.apa.org/doi/10.1037/0022-006X.52.4.625

World Health Organization. (2013). Manual for the International Classification of Diseases (ICD-10): Injuries and causes of death. Geneva, Switzerland.

Zagar, A. K., Zagar, R. J., Bartikowski, B., \& Busch, K. G. (2009). Cost comparisons of raising a child from birth to 17 years among samples of abused, delinquent, violent, and homicidal using victimization and justice system estimates. Psychological Reports, 104, 309-338. https://doi.org/10.2466\%2FPR0.104.1.309-338

Zagar, R. J., Kovach, J., Busch, K. G., Zablocki, M., Osnowitz, W., Neuhengen, J., ... \& Zagar, A. K. (2013). Ammons Quick Test validity among randomly selected referrals. Psychological Reports, 113, 1-32. http://dx.doi.org/10.2466/03.04.PR0.113x29z0

Zagar, R. J., \& Grove, W. M. (2010). Violence risk appraisal of male and female youth, adults, and individuals. Psychological Reports, 107, 3, 983-1009. http://dx.doi.org.10.2466/02.03.16.PR0.107.6.983-1009

Zagar, R. J., Arbit, J., Busch, K. G., Hughes, J. R., \& Sylvies, R. (1991). Homicidal adolescents: a replication. Psychological Reports, 67, 1235-1242. http://prx.sagepub.com/content/67/3_suppl/1235.full.pdf

Zagar, R. J., Arbit, J., Hughes, J. R., Bussell, R. E., \& Busch, K. G. (1989). Developmental and disruptive behavior disorders among delinquents. Journal of American Academy of Child and Adolescent Psychiatry, 28, 437-440. http://dx.doi.org/10.1097/00004583-198905000-00023

Zagar, R. J., Busch, K. G., Grove, W. M., Hughes, J. R., \& Arbit, J. (2009). Looking forward in records of young adults who were convicted of homicide or assault as youth: risks for reoffending. Psychological Reports, 104, 129-154. http://www.dx.doi.org/10.2466/PRO.104.129-154

Zagar, R. J., Grove, W. M., \& Busch, K. G. (2013). Delinquency best treatments: How do we divert youth from crime and save detention costs. Behavior Sciences and the Law, 31, 381-396. http://dx.doi.org/10.1002/bsl.2062

Zagar, R. J., Kovach, J., Basile, B., Grove, W. M., Hughes, J. R., Busch, K. G., .. \& Zagar, A. K. (2013). Finding workers, offenders or students most at-risk for violence: actuarial tests save lives and resources. Psychological Reports, 113, 685-716. http://dx.doi.org/10.2466/16.03.PR0.113x29z3

Zagar, R. J., Zagar, A. K., Arbit, J., Bartikowski, B., Busch, K. G., Bussell, R. E., ... \& Stark, R. (2009). Predicting and preventing homicide: A cost effective empirical approach from infancy to adulthood, Psychological Reports, 104, 1-377. https://dx.doi.org/10.2466/PR0.104.1.1-377

Zagar, R. J., Zagar, A. K., Busch, K. G., Garbarino, J., Ferrari, T., Hughes, J. R., ... \& Basile, B., (2016). Finding high 
risk persons with internet-based tests to manage risk: A literature review with policy implications to avoid tragedies, save lives and money. Review of European Studies, 8(1), 1-31. https://dx.doi.org/10.5539/res.v8n1p

Zaloshnja, E., Miller, T. R., \& Spicer, R. S. (2000). Costs of large truck and bus involved crashes. U.S. Department of Transportation. Washington, DC: Federal Motor Carrier Safety Administration.

\section{Copyrights}

Copyright for this article is retained by the author(s), with first publication rights granted to the journal.

This is an open-access article distributed under the terms and conditions of the Creative Commons Attribution license (http://creativecommons.org/licenses/by/4.0/). 